


$$
\begin{aligned}
& \text { liarsh C D }
\end{aligned}
$$

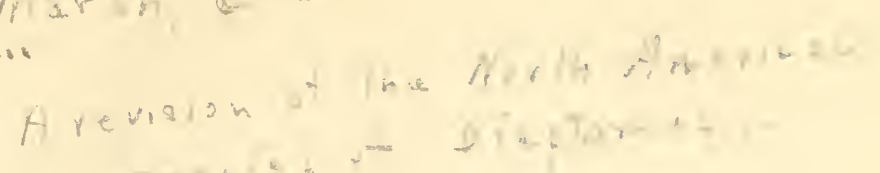

$$
\begin{aligned}
& \text { Trans intisiona in Aevals. }
\end{aligned}
$$

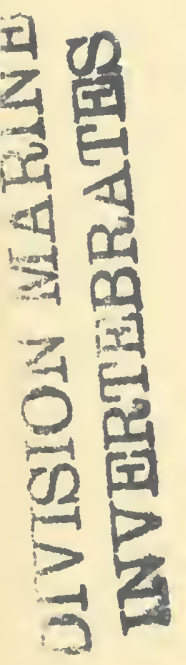




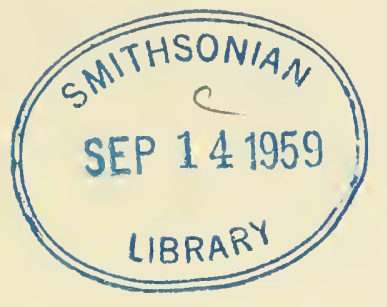




\title{
A REVISION OF THE NORTH AMERICAN SPECIES OF DIAPTOMUS.
}

\author{
C. DWIGHT MARSH.
}

(With P'lates $\mathrm{Xr}-\mathrm{Xx}$ III)

\section{INTRODUCTIOX.}

The genus Diaptomus is of special interest to the student of plaukton, because, in so many cases, it forms the major portion of that part of the plankton which is available as food for fishes. It is true that in plankton-rich bodies of water, the largest collections consist, for the most part, of vegetable material, but a large proportion of the regetalle material is waste so far as concerns its serving directly as food for animals. It is true, too, that in some cases other Copepola or Cladocera may form the bulk of the animal part of the plankton, but conmonly it is Diaptomus that is most prominent.

The genus ocenrs the world orer, and is found not only in lakes, but in rumning streams and in temporary pools. While it is found so widely, however, but few of its species are widely distributed. Most of the species of Cyclops in America are identical with those of the other continents, but this is true oi none of the species of Diaptomus. All of our species are peculi ar to this continent, and some of them have a habitat of relatively narrow limits. It would appear that Diaptomus is quite susceptible to the influences of its environment, and this fact makes the study of the genus of peculiar interest.

In connection with lake work the author has been studying Diaptomus, as a side issue, for sone years, and has at length accumulated enough material, apparently, to warrant publica- 
tion. The collections studied have covered a wide range of comntry, from the Saskatchewan district on the north to Mexico and Cuba on the south, and from Long Island on the east to Washington and California on the west. It must not be assumed, however, that the collections give any complete idea of this wide extent of territory. Most of the collections are of a sporadic character. Outside the states of Wisconsin, Michigan, Ninnesota and Illinois, nothing like any complete exploration has been made. Within the limits of these states, fairly complete work has been done. In the rest of the country, much less is known of the older states of the East than of the new states and territories of the West.

A study of this material shows a number of new speeies, and throws new light on the relationships of those already known.

It has been the ambition of the author to monograph the genus, so far as North American species are concerned, but this will not be possible for some years, for very extensive collections must be made before such a work ean be possible. Meantime the important part played by the genus in plankton makes it desirable that what is already known should be put in such shape that the student of plankton may be able to identify his species. This is very difficult to do at the present time. The only papers, ostensibly covering all the North American species, are those of Herrick and Turner, and Schacht, and neither of these, for various reasons, can be easily used for the determination of species. It is very difficult, even for one who is acquainted with the genus, to recognize species without figures, and for the average student of fresh water forms, who presumably has no special training in the study of Entomostraca, it becomes a discouraging task even to gness at the species. With suitable figures, however, any one, who has the patience to make the necessary dissections, ought to be able to determine correctly the species he has in hand. The present revision is undertaken with the hope that it may not only be a contribution to our knowledge of the genus, but that it may prove a distinct help to those who are studying the problems of limnology, but, have no special knowledge of Entomostraca. It 
seems unfortunate that so many papers on plankton list the Diaptomi simply under the generic name without an attempt to distinguish species, thus detracting much from the value of the observations, inasmuch as the Diaptomi have very distinct individual peculiarities, and react very differently to their environments.

With this in view, the author has attempted to provide suffcient figures of each species so that its identity cannot be a questionable matter. The original plan involved personal acquaintance with each species, and figures from specimens actually in the collections studied. It was found impossible, however, to carry this out in every case; for example, it was found impossible to get material of D. novamexicanus, as Herrick had preserved none of the original material. The papers describing Pearse's species Wardi and spatulocrenatus were received while this paper was in press and after the plates had been made, so that it was impossible to provide figures, or to do much more than to give the species their proper place in the classification. So, in other cases, becanse of imperfect cataloging of museum material, it was impossible to get specimens of the animals originally studied. Therefore, in some cases, it has been found necessary to reproduce the original figures of the author's of the species. Most of the figures, however, are from material in the collection of the author.

As the result of studies on other collections, it is hoped, before many years, to supplement this work, so that we may get more rearly a synopsis of all the North American species. Meanwhile it is to be expected that intermediate forms will be discorered which may change materially the specific limits as they appear at the present time.

The author would express his grateful acknowledgment to all who kindly aided in this work by assisting in making the collections on which it is based. To the following he has been especially indebted: to Professor E. A. Birge of the University of Wisconsin, not only for the exchange of material from Wisconsin, but for extensive collections made in the southeru states; to Professor Chauncey Juday of the University of Cali. 
fornia, for collections from Indiana, Colorado and California; to Professor Jacob Reighard of the University of Michigan, for collections from the Great Lakes and from the inland lakes of Michigan; to Professor II. B. Ward of the University of Nebraska, for collections from Nebraska, Colorado and Cali. fornia; to Professor C. F. Baker of the Stacion Agronomica, Santiago, Cuba, for collections from Nevada, California, Mexico, Cuba and the southern states; to Professor B. H. Brown of Whitman College for collections from Washington; and to his former pupil, Russell T. Congdon, for collections from the Saskatchewan district.

Many others have collected for me more or less material, and without this assistance, this revision wonld have been impossible.

A SPECULATION IN lEGARD TO TIIE AFFINITIES OF THE NORTH AMERICAN SPECIES OF DIAPTOMUS.

I speak of this as a speculation, for the present condition of our knowledge in regard to this genus hardly justifies the use of the term theory. Until vastly more complete collections have been made, the affinities of the species and the relationships of the genus to other genera can only be guessed at.

\section{Origin of the genus.}

Practically nothing is known of the origin of the genus. Of course, its ancestors were marine, but there are no marine forms at the present time very closely related to it. It is generally considered that its nearest relative is the gemus Drepanopus, of which three species are known. These are found in the southern oceans in a few localitics, the latitude varying from 30 to 47 degrees.

We have no geological knowledge of the history of Diaptomus. We may assmue that it was separated long before the glacial period, perhaps far back of that time, and that, prior to the invasion of the ice, the species of the eastern and western continents were distinct. 
Effect of the glacial period on distribution.

Before the glacial period, we may suppose that the waters of North America were peopled with species of Diaptomus. Inasmuch as the continental conditions differed less than those of the present time, it is probable that the number of species was smaller. This is probable, too, from the fact that the means of communication from one body of water to anothe: was probably easy, so that there was less opportunity for the effect of isolation. As the period progressed, the genus must have been driven further and further towards the south, being limited, on the north, during the period, very nearly to the southern limit of the ice. This limit would not have been cxact, for species of Diaptomus live in the coldest waters.

During the decline of the glacial period it is fair to assume that, as the ice retreated, the Diaptomi followed towards the north. Inasmuch as the species of Diaptomi at the present time are limited in their distribution by climatic influences, wo may assume a gradual change in the species in any given locality as the climate changed. The forms which had been living close to the ice border would retreat towards the Aretic, or might remain as a fauna relicta if local conditions were such as to make this possible.

If the above assumptions in regard to the origin of the genus and its geological history are accepted, we must suppose:-

First, that inasmuch as there were several, perhaps many, species before the glacial period, our modern species will probably be divided into groups, according to their phylogeny, but it is unlikely that we can trace to any one line for all species.

Second, the most primitive species will be the furthest nortl. We may expect to find in Arctic or sub-Arctic regions the forms most nearly related to those that dwelt in the United States during the glacial period, and these forms will be found further south only as a part of a fauna relicta unless they have been able to adapt themselves to great variations of climate; $25-$ S. \& A. 
generally speaking, the species of this genus adapt themselves to variations of climate only to a limited extent.

Third, if climatic conditions tend to produce new species, the more recently dereloped species would be in the south under warmer temperature conditions, and in the west where isolation as well as climate comes in as an important factor.

Some emphasis should be placed on the effect of isolation, for experience shows that the distribution of Diaptomi is brought about largely, if not entirely, by actual water carriage. It is, of course, possible that birds and winds may carry the animals or their eggs in some cases, but this is not an ordinary method. This is shown by the fact of the isolation of particular species in certain lakes. For example, D. Reighardi occurs in lakes in the Beaver Islands, but not in Lake Michigan close by. D. Birgei has been found in but one locality in Wisconsin; this also is true of $D$. siciloides, which is found only in Cedar lake, Washington county. There may be other localities for these species, but Wisconsin has been pretty thoroughly explored without finding them.

DISTRIBUTION OF SPECIES.

I have recognized thirty-four species of Diaptomi in North America, distributed as follows. It is to be understood that these are simply the known localities, snd it is possible in many cases that the distribution is much wider. Anything like thorough collections have been made only in Illinois, Michigan, Wisconsin and Indiana. Many collections have been made in the states in the Mississippi valley, and scattered collections in the mountain regions of the West. The immediate vicinity of Lincoln, Nebraska, has been explored by the Department of Zoology in the University of Nebraska. I have only one set of collections from the Northwest Territory. The lakes of the eastern United States are mexplored.

D. albuquerquensis, New Mexico, Mexico, Colorado.

D. Ashlandi, Idaho, Washington, Great Lakes, Indiana, Michigan, Wisconsin, Oregon. 
D. asymmetricus, Cuba.

D. Bateri, California.

D. Birgei, Wisconsin, Indiana, Long Island.

D. clavipes, Iowa, Nebraska, Colorado.

D. conipedatus, Lonisiana.

D. dorsalis, Louisiana.

D. Eiseni, Califormia, Nebraska.

D. franciscanus, Califormia.

D. Judayi, Colorado.

D. leptopus, Massachusetts, Wisconsin, Mllinois, Northwest Territory, Colorado, Mississippi valley generally.

D. Lintoni, Yellowstone park.

D. minutus, Great Lakes, Yellowstone park, Michigan, Wisconsin, Newfoundland, Greenland, Iceland. Not found south of Wisconsin.

D. mississippiensis, Mississippi, Louisiana, Florida.

D. novamexicanus, New Mexico.

D. nudus, Colorado.

D. oregonensis, Oregon to Michigan, Nor'thwest Territory kn Iowa, Illinois, Indiana and Massachusetts.

D. pallidus, north to Wisconsin and Minnesota, south to Louisiana, west to Texas and Colorado, east to Illinois, Mississippi valley.

D. purpureus, Cuba.

D. Reighardi, Michigan.

D. saltillinus, Nebraska.

D. sanguineus, Massachusetts, New York to Minnesota, oouth to Alabama; reported from Nebraska and Washington.

D. shoshone, IVyoming, Colorado.

D. sicitis, Great Lakes, Wisconsin, Michigan, Wyoming, Minnesota, Illinois, Nebraska.

D. siciloides, California, Illinois, Indiana, Wisconsin, Colorado, Nebraska.

D. signicauda, California, Nevada, Colorado.

D. spatulocrenatus, Nantucket.

D. stagnalis, Illinois, Minnesota, Ohio, Kentucky, Alabama.

D. tenuicaudatus, Saskatchewan. 
388 Wisconsin Academy of Sciences, Arts, and Letters.

D. Trybomi, Oregon.

D. Tyrelli, California.

D. Wardi, Washington.

$D$. washingtonensis, Washington.

It will be noticed that some are restrieted pretty closely to the Mississippi valley, some to the gulf states, and others to the northern tier of states. Generally speaking, within rather wide limits, the distribution is one of latitude. The most northern species, $D$. minutus, ranges from Iceland to southeri Wisconsin, $D$. oregonensis has the same southern limit and has been found is far north as the Saskatchewan, D. pallidus ranges from Wisconsin to the Gulf, while $D$. mississippiensis is confined to the gulf states. Strietly confined to the western part of the United States and mostly in the mountain regions, are D. albuquerquensis, clavipes, Eiseni, franciscanus, Judayi, Lintoni, novamexicanus, nudus, saltillinus, shoshone, signicauda, Trybomi, Tyrelli, Wardi and washingtonensis.

The greater number of species in the $W^{\prime}$ est is doubtless largely aceounted for by the results of isolation, but it should be remembered that collections have been made in only a few localities, and it may be found both that the known species have a greater range than now appears, and that intermediato forms may come to light which will affect present speeies limits.

RELATION OF STRUCTERE TO IIABITAT.

Except in a very general way, it is difficult to correlate habitat and structure. Still, certain facts are evident.

1. Peculiar, bizarre eharaeters are more apt to appear in animals living in shallow waters and with a narrow range of habitat. This appears in the dorsal process of $D$. dorsalis, and in the hook on the fifth foot of the male in D. clavipes. The process of the first abdominal segment of the female is found only in $D$. signicauda and the species associated with it, and these are limited to the mountain regions. This principle, however, does not apply as widely as we should expect.

2. There is a marked distinction between species living in deep water, and in shallow. The deepwater, or limnetic, forms 
are generally transparent, apparently never permanently colored. Their bodies are elongated, and their appendages are long and slender. The species of littoral liabitat, or dwelling in shallow water, have stouter bodies, are generally larger, doubtless due to greater abundance of food, their appendages are much shorter, and they are frequently highly colored. $D$. shoshone is one of the most striking examples of these peculiarities. They are also very noticeable in $D$. leptopus and $D$. sanguineus.

STRUCTURAL REIATIONSHIPS OF THE SPECIES.

In this connection will be discussed only those peculiarities used for the separation of speeies. It is understood that this cover's only a surall part of the subject, but it will be limited with some preeision to what is known. The characters used for the determination of species are the following:

1. The form and segmentation of the cephalothorax.

2. The form and segmentation of the abdomen of the female. Noticeable are the presence or absence of lateral spines or of a caudal process on the first segment.

3. The length of the antennae, and the armature of the last three segments of the male antemua. This armature consisis, in the main, of hyaline lateral lamellae and of a process on the antepenultimate segment which varies, being sometimes a hook, more or less prolonged, sometimes an elongated affair which may be armed with teeth.

4. The form of the fifth feet of the female. A fifth foot, as can be seen by referenee to the plates, consists of two basal segments, an exopodite of two or three segments, the second segment produced into a hook, and an endopodite of one or two segments. This may vary in the following ways:

a. In the form and size of the spine of the first basal segment.

b. The exopodite may be two- or three-segnnented, and, when two-segmented, may have two or three lateral spines.

$c$. 'The endopodite may be either' one-or two-segmented, and varies in lengtl and in the size of the apical spines. 
5. The form of the fifth feet of the male. In the male fifth feet, there are two basal segments. In the right foot, the exopodite consists of two segments, the second segment bearing a lateral spine and a terminal hook. The endopodite is one- or two-segmented. In the left foot the exopodite is composed of two segments, the second segment terminated with two processes. The endopodite is onc- or two-segmented. The principal modifications are these:

a. Form and size of the spines of the first basal segments.

b. Position of the lateral hairs of the second basal segments.

$c$. Relative lengtlıs of the segments of the exopodite.

$d$. Position of the lateral spine of the second segment of the exopodite.

e. Form and size of the terminal hook.

$f$. Form and size of the processes and lamellae which sometimes occur on the segments of the right foot.

g. Form of terminal processes of second segment of the exopodite of the left foot.

$h$. Form, size and segmentation of the endopodite. It may be one- or two-segmented, may be rudimentary, or may acquire considerable length. Its tip may be armed with setae, or with two more or less prominent spines.

PRIMITIVE STRUCTURAL CHARACTERS.

In discussing the structural relationship of the species, it is necessary, if any phylogenetic conclusions are to be reached, to determine what are the more primitive characters. This is a matter of some difficulty and must be largely, perhaps, conjecture.

The typical copepod appendage consists of two basal segments with three-segmented exopodite and endopodite. We may assume that the fifth feet of both sexes have been derived from such a typical structure by a process of reduction. I call this an assumption, for I do not feel certain that it is true. It seems, however, most probable in the light of present knowledge. Granting this assumption, it would follow that the most primitive form would be the one that most nearly approaches 
this type; the more nearly equal in length the right and left feet, the more primitive the form; the more nearly the endopodite approaches a three-segmented structure of the same length as the exopodite, the more primitive the form, etc. Of course, this reduction may not have been correlated in different structures; for example, a two-segmented endopodite might pos. sibly be found in a recent form, although in most a one-segmented condition caxists. Generally speaking, however, it wouldi be true that a specias would be considered the more primitive in proportion as it approaches more or less closely to a form having its feet composed of three-segmented rami. It is to be supposed that this reduction may have gone on at the same time in two or more lines, so that the fact of a similar stage of reduction in the segments of the feet would not in all cases imply close relationship, although many times this would be true. The common presence in two or more forms of a structure that was developed rather than left behind in the process of reduction, would be pretty good evidence of close relationship.

It must be borne in mind, too, that very little is known of the amount of variation in the structures of Diaptomi, and further knowledge may modify present conchusions. For example, it is difficult to correlate the peculiar armature of the antepenultimate segnent of the right male antenna with other structures, and it is possible that it may appear that these structures are much more variable than is now supposed.

THE OREGONENSIS GROUP.

This group inciludes D. oregonensis, Reighardi, mississippiensis, pallidus, and possibly Bakeri and franciscanus. Leaving Bakeri and franciscanus out of consideration for the time being, the members of the group agree in the following characteristics:

All are without a distinct appendage on the antepenultimate segment of the male right antenna. All have the lateral spine near the end of the second segment of the right male exopodite, and have a small spine near the inner margin of the same segment. The terminal processes of the left foot of the male are 
digitifom in $D$. oregonensis, franciscanus and Reighardi, the inner one is falciform in D. pallidus, while in D. mississippiensis and D. Balieri they are elongated and digitiform. In the female the fifth feet are nearly the same in all these species. All have two spines on the second segment of the exopodite. The lateral spines of the female abdomen are most pronounced in D. Balieri and D. mississippiensis, but are not large in any of the species. In D. oregonensis the right and left feet are nearly of the same length. Tn the other cases there is considerable difference between the lengths of the two feet.

As to distribution, D. oregonensis is known to live from about the parallel of 42 degrees north to the Saskatchewan region, and very likely has a still further extension towards the Arctic. D. Reighardi is localized, so far as is known, to the northem part of the sonthern peninsula of Michigan. D. mississippiensis is found only in the gulf states. D. pallidus is found in the Mississippi valley from Wisconsin south, and as far west as the Rocky mountains. D. Batieri and D. franciscamus have been found only in California, and each only in a single locality, although, of course, it is probable that they will be found to have a wider distribution.

It seems to me that $D$. oregonensis, pallidus, Reighardi and mississippiensis have clearly a very close relationship, as shown hy the absence of the antennal appendage and the very close resemblance in the male fifth feet; this is noticeable in the proportions of the segments, the location of the lateral spine, and especially in the presence of the small spine near the inner margin. D. Balieri and D. franciscanus have this small spine, which makes me feel quite certain that they must be in the same line.

The phylogeny of part of the group seems to me quite clear. $D$. oregonensis is the most prinitive form. Its wide distribution in the cold temperate region is entirely in harmony with this supposition. It or its immediate ancestor inhabited the waters of the United States south of the ice at the height of the glacial period. As the ice disappeared, it gradually moved towards the north, adapting itself only in a slight degree to 
the changes of the environment. D. pallidus may be derived from $D$. oregonensis. It has gradually taken the place of $D$. oregonensis through the Mississippi valley. The difference in structure between $D$. oregonensis and $D$. pallidus is doubtless due to minor influences of the environment, accompanied by isolation. It is not likely that the morphological differences can be traced to any specific influences of environment. $D$. mississippiensis, which is still further removed from $D$. oregonensis, is of later origin, and in a more limited habitat has developed more pronounced structural differences.

D. Bakeri and D. franciscanus differ from the other members of the group in that they have an appendage on the antepenultimate segment of the right male antenna. If it should appear that this appendage is an invariable character, these two species should, doubtless, be separated from the group. The position of the lateral spine on the right exopodite of the male fifth foot and the presence of the small inner spine on the same segment make one feel that these two specres must belong in the cregonensis group.

The endopodites of the male fifth feet in D. Baheri are twosegmented, and the right exopodite in D. franciscanus is frequently two-segmented. The endopodites of the female fifth feet in $D$. Bakeri are also two-segmented, and in both $D$. Bakeri and $D$. franciscanus the exopodites of the female fifth feet are three-segnnented. Thus D. Balieri and D. franciscamus have many of the characteristics of what I have assumed to be primitive structures, and it is possible that these peculiarities have been retained in their somewhat limited habitat; this must be a matter of conjecture, however, because of our slight. knowledge of the distribution of the California species.

The relationships of the members of the group may then be expressed in the following way: 


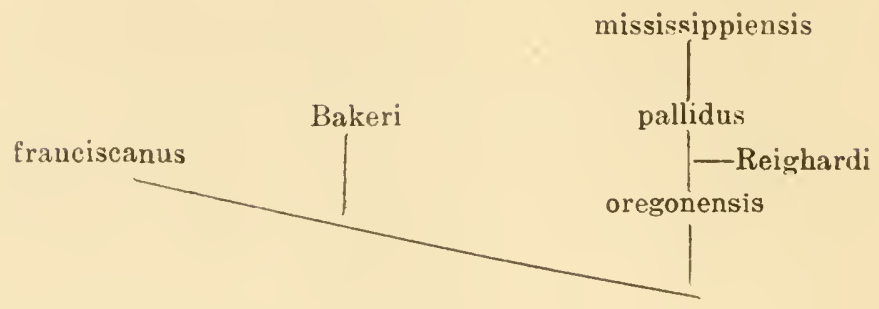

THE TENUICAUDATUS GROUP.

This group includes D. tenuicaudatus, sicilis, Ashlandi, minutus, Birgei, siciloides, Wardi and shoshone. All, with the exception of Birgei and siciloides, agree in having a slender straight appendage on the antepenultimate segment of the right antenna of the male; these, however, are not the only species with this appendage. The male fifth feet of $D$. tenuicaudatus, $D$. sicilis and $D$. shoshone resemble each other very closely. In $D$. Ashlandi and D. Birgei the most marked difference is in the position of the lateral spine.

$D$. Birgei has an exceedingly short appendage on the antepenultimate segment of the male right antenna, and $D$. siciloides has a short hook. In all members of the group, with the exception of $D$. shoshone and $D$. minutus, there is a hyaline lamella on the posterior surface of the first segment of the right exopodite. This peculiarity is found in some species ontside this group, especially in those of the signicauda group, and may indicate a common structural relationship between the groups. D. minutus differs not only in the position of the lateral spine, but in the form of the terminal hook, and in the rudimentary right endopoditc. In the female fifth foot, too, D. minutus differs in that the endopodites are rudimentary, and that they have three spines on the second segment of the exopodite. D. shoshone has elongated terminal spines on the endopodite of the female fifth foot and has a distinctly three- 
segmented exopodite. $D$. shoshone by its size is separated from the rest of the group, but its structural relationships seem to be very close.

D. minutus is most widely distributed, being found from tha northern United States to Greenland : nd Iceland, but not sn the Eastem Continent. D. Ashlandi and D. sicilis, so far as known, are limited to the northern tier of states in the United States. D. Birgei and D. siciloides belong to warmer waters but probably do not occur south of the Ohio river, while $D$. shoshone is peculiar to the mountain region of the West. $D$. tenuicaudatus is a recent find, and is, so far, reported from only one locality, in the Saskatchewan regiun. D. sicilis and $D$. Ashlandi are distinctly lovers of cold water. In Green lake $D$. sicilis cecurs in the winter months and $D$. minutus in the summer 1Eonths. (Marsh, '97, Marsh, '03.) D. tenuicaudatus is considered the most primitive form because of the slender female abdomen without armature, the nearly equal length of the male fifth feet, and the two-segmented endopodite of the left fifth foot of the male. $D$. sicilis is the most nearly related to $D$. tenuicaudatus. $D$. shoshone comes very close to it, but if it is in this line it must have been subjected to peculiarly favorable cireumstances of food to have developed such an enormous size. $D$. Ashlandi might easily have been derived from $D$. tenuicaudatus, but the separation must have taken place at a comparatively remote time. D. siciloides and $D$. Birgei are somewhat more specialized forms from the same stock as $D$. sicilis. D. minutus, according to the standard I have set up, is the most specialized of the group; there is a marked difference in the lengths of the fifth feet of the male, and there is a striking reduction of the endopodites in the fifth feet of both sexes. The only noticeable primitive character is the three spines of the second segment of the exopodite of the fifth feet of the female. From its wide distribution we might well think of $D$. minutus as an early form from which the others have been derived, were it not for its specialized characteristics. 'As it is, we must think of it, perhaps, as not derived from $D$. tenuicaudatus, but as having a common ancestry with 
this form. The relationship of this group, then, may be expressed by the following diagram:

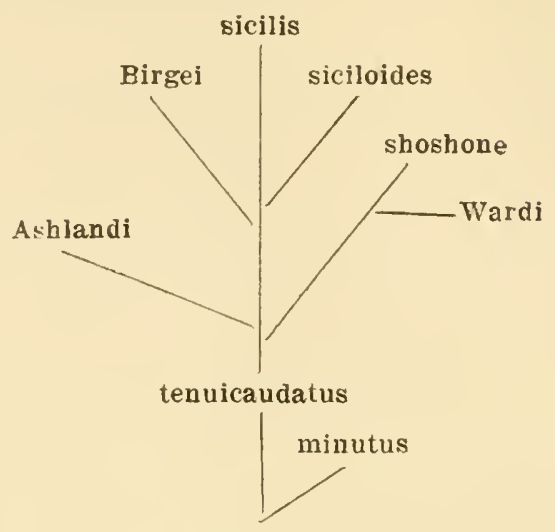

D. Tyrelli has no appendage of the antepenultimate segment of the right male antenna, but the structure of the male fifth foot leads me to think that it should be classed with this group. It must be considered as somewhat distinctly separated from the rest of the group, and its phylogeny is uncertain.

THE LEPTOPUS GROUP.

This includes $D$. leptopus, leptopus var. piscinae, conipedatus, stagnalis, Lintoni, spatulocrenatus and clavipes...D. conipedatus, D. spatulocrenatus and D. stagnalis have a hook on the antepenultimate segment of the right antenna of the male. The others have a lateral hyalice lamella. D. leptopus, $D$. leptopus var. piscinae, $D$. conipedatus and $D$. clavipes have a hook in the posterior face of the second basal segment of the right fifth foot of the male, this hook being most pronounced in the ease of $D$. clavipes. The published figures do not indicate the presence of such a hook in D. Lintoni or $D$. stagnalis, but Schacht's description of $D$. stagnalis speaks of the presence of a "large, smooth, hyaline lamella." This may represent the hook of the other species. In the female fifth foot, the second segment of the exopodite has either two or three spines in $D$. leptopus, and three in $D$. clavipes, $D$. conipedatus, D. spatulocrenatus and D. Lintoni. In D. stagnalis the exopodite is distinctly three-segmented. The endopodites of the female fifth feet in D. stagnalis are two-segmented. 
D. Lintoni has been found only in the Yellowstone park. $D$. conipedatus has thus far been found only in Louisiana, and $D$. clavipes in Iowa and Nebraska. D. spatulocrenatus has been found only in the island of Nantucket. D. stagnalis probably occurs generally throughout the Mississippi valley, and $D$. leptopus not only in the Mississippi valley but north into British America.

I have called this the leptopus group because $D$. leptopus is the most common species. In many respects, however, D. stag. nalis may be considered the more primitive. This is notably the case in the characters of the female fifth feet-the threesegmented exopodite, and the two-segmented endopodite. From its distribution, one would think of $D$. leptopus as the more ancient form. In the antennal armature, D. stagnalis, D. conipedatus, D. spatulocrenatus and D. Lintoni are most uearly alike.

I think one can do little more than guess at the relationships of the members of the group. D. clavipes is apparently the most specialized. The probable relationships may be put, provisionally, as follows:

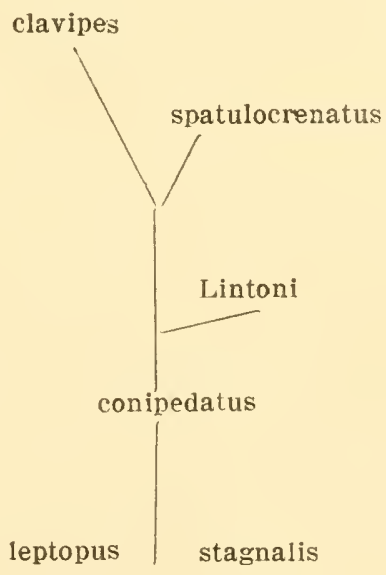

THE SIGNICAUDA GROUP.

This consists of $D$. signicauda, washingtonensis, nudus and Judayi. They are put together because of the common character of the posterior process on the female abdomen. D. Judayi has a straight process on the antepenultimate segment of the right antenna of the male. The others agree in having a hook. $D$. 
signicauda and D. Judayi have a hyaline lamella on the first segment of the right exopodite. D. washingtonensis alone has the primitive character of a two-segmented endopodite in the male fifth foot. D. Judayi has the most pronounced spines on the first segment of the female andomen. It seems that there. should be no question of putting these speeies together on the grround of the posterior process of the first segment of the female abdomen, although this appears late in the development of the individual and it is very possible that the peculiarity originated in different lines.

With this group I should place D. Trybomi, although it is somewhat aberrant in many details of strueture. The asymmetry of the female abdomen would lead in to conjecture a relationship with the signicauda group, but a relationship much more remote than that of the other members. The male fifth foot, while peculiar in many respeets, yet bears a marked resemblance to the fifth feet of the group in question. In the "dorsal hump," too, there is a reminder of $D$. signicauda. The group seems to be nearly related to the tenuicaudatus group, and is probably an offshoot of it.

One speeies of this group can hardly be picked out as the most primitive. I have ealled it the signicanda group, simply because that was the first of the species to be described.

THE ALBUQUERQUENSIS GROUP.

In this group are inchded D. alburuerquensis, dorsalis, asymmetricus, purpureus and saltillinus. All have a hooked process on the antepenultimate segment of the right antenns of the male. The principal reason for puting them together, however, is the similarity of the male fifth feet. In all, the endopodites are short and composed of a single segment. In all, exeept $D$. albuquerquensis and $D$. saltillinus, there is a hyaline process on the inner margin of the second basal segment of the right foot; $D$. saltillinus has a tuberele on the inner margin, and both $D$. saltillinus and $D$. alluquerquensis have a peculiar process on the posterior surface of this segment. In all there is a transverse ridge on the posterior surface of the first segment of 
the right exopodite; in most cases this runs across the segment. In all, except $D$. saltillinus, there is an oblique ridge on the posterior surface of the second segment of the right exopodite. In all, except $D$. purpurens, the terminal segment of the exopodite of the left foot is armed with a digitiform proce is and a slender articulated spine; this spine in $D$. saltillinus is curved. The fifth feet of the females, too, resemble each other. In all, the exopodites are three-segmented. The endopodites are short, and in all, except $D$. saltillinus, are armed with two rather prominent spines. The female abdomens, with the exception of $D$. asymmetricus, resemble each other; in $D$. dorsalis and $D$. purpureus the first segment is especially loug and slender, but it is stouter in $D$. saltillinus and $D$. albuquerquensis. In $D$. asymmetricus the general form is like that of $D$. purpureus, but there is the marked peculiarity of the lateral process.

$D$. albuquerquensis, $D$. dorsalis and $D$. saltillinus differ from the other species of the group in the peculiar dorsal processes of the fifth thoracic segment.

I have called the group the albuquerquensis group, not because there is any reason to think that this species is the most primitive, but because it was the first described. There would seem to be little question of the close affinity of all the members of the group. D. saltillinus differs more widely than do the others. D. saltillinus, too, is the most northern species, the others being distinctly sonthern, $D$. alburuerquensis being found in Colorado, New Mexico and Mexico, and D. purpu reus and $D$. asymmetricus in Cuba.

It is hardly possible, with the present knowledge, even to guess at the phylogenetic relationships of the group.

D. sanguineus and D. Eiseni I am not prepared to locate, even tentatively. It should be noticed, perhaps, that $D$. albuquerquensis, dorsalis, saltillinus, Trybomi, sanguineus and signicauda all have a pronounced dorsal process or hump. This may indicate some relationship, but it does not seem clear enough to lead to a grouping of these species.

Of the groups I have formed, it seems to me that the tenuicaudatus group is the nearest to the primitive form; it does 
not appear likely, however, that the others are derivatives of this, but rather that they go back to a common ancestry which resembled tenuicaudatus more nearly than the others.

FACTORS CONTROLLING THE DISTRIBUTION OF THE DIAPTOMI.

I think it will appear evident from the discussion of the groups of the Diaptomi that there are two great factors controlling their distribution. One is ease of water communication, the other is temperature. There is no reason to think that, under ordinary circumstances, species are distributed in any way except by water carriage. The existence of species isolated in particular localities seems pretty conclusive evidence of this; this is seen in the peculiarly localized habitat of $D$. Reighardi, in the distribution of D. Birgei, and in the presence of $D$. siciloides in Cedar lake, Wisconsin, although it has been found in no other part of the state.

An examination of the distribution of the nembers of the different groups shows very clearly the prominence of the two factors mentioned above. In the oregonensis group, D. Reigh. ardi, $D$. Bakeri and $D$. franciscanus are localized species. $D$. oregonensis is a distinctly northern species, while D. mississippiensis is as distinctly sonthern. D. pallidus has a somewhat wider range, but apparently through communicating waters.

Of the tenuicaudatus group, none are found in the South. $D$. tenuicaudatus has been found only in the far North. $D$. minutus has the widest range, being found from Iceland to southern Wisconsin. D. sicilis and D. Ashlandi are confined to the northern tier of states, while $D$. siciloides and $D$. Birgei are probably limited, speaking in a very general way, to the region between the parallels of $39^{\circ}$ and $43^{\circ}$. The distribution with reference to latitude is very marked in the case of most of the members of this group.

Of the leptopus group, D. leplopus is the most widely distributed, being found not only through the Mississippi valley out north into British America. D. clavipes and D. Lintoni are probably somewhat localized. D. stagnalis is found from 
Illinois south, while $D$. conipedatus is found only in the South. Here again is pretty clear evidence of the importance of the factors of water carriage and temperature.

The signicauda group is confined to the mountain region of the West, and I assume it to be a product of isolation. There is no evidence of the effect of temperature in the distribution of the members of this group.

The albuquerquensis group is distinctly sonthern. D. saltillinus, the most aberrant member of the group, is found as far north as Nebraska and as far south as Florida, if I am correct in supposing that $D$. albuquerquensis Schacht is D. saltitlinus Brewer. The distribution of this group, as in the case of the others, gives distinct evidence of the effect of latitude.

Both Forbes and Ward, following European authors, have thought that elevation was a controlling factor in the distribution of fresh water organisms. So far as Diaptomi are concerned, I see no reason for thinking that elevation has any effect in controlling the distribution of our American species, except in the indirect way that elevation is accompanied by low temperature. It seems clear to me that the species of $D i$ aptomi are commonly confined within rather narrow linits of temperature.

\section{Diaptomus Westwood.}

1785. Cyclops O. F. Müller.

1820. Monoculus Jurine.

1836. Diaptomus Westwood.

1838. Cyclopsina Milne-Edwards.

1838. Glaucea Koch.

1848. Cyclops Nicolet.

1889. Diaptomus De Gnerne and Richard.

1897. Diaptomus Schacht.

Althongh the number of described species of Diaptomus has greatly increased since the publication of De Guerne and Richard's Révision, and it might be thought wise to subdivide the genus, it has not seemed to me best. The description as given by them is exact, and it seems undesirable to make any chango in it. 
The following description is taken from the Rérision withont any change: ${ }^{1}$

"Cephalothorax segmentis constans $T$, quorum anterior'a duo indistincte sejuncta caput componmut. Segmentum ultimum thoracale in femina sat magnum, postice in medio profundius emarginatum adque latera saepius utrinque in laminam exiens biangulatam. Abdomen breve thorace angustius. in femina (ramis candalibus inclusis) segmentis 4, quorum primum in parte antica dilatatum saepiusque utrinque mucrone laterali armatum est; in mare vero segmentis 6 ejusdem fere latitudinis compositum. Rami candales setis 5 miarticulatis et plumosis, setaque alia multo tenuiore intus adfixa praediti. Frons

1 The following translation of the original account of the genus Diaptomus may be given:

Cephalothorax always of seven segments, of which the two anterior, indistinctly separated, form the head. The last thoracic segment in the female is rather large, posteriorly in the middle rather deeply emarginate, and quite frequently produced laterally on both sides into a biangulate lamina. Abdomen short, narrower than the thorax, in the female, including the caudal rami, of four segments, of which the first is dilated anteriorly, and commonly armed with a lateral spine on each side; but in the male it is composed of six segments of nearly equal width. The caudal rami are armed with five uniarticulate plumose setae, and with another much more slender seta attached on the inner side. The front is provided with two very minute tentaculiform appendages. The antennae of the first pair are composed of twenty-five segments, which increase a little in length toward the tip; the right antenna of the male is geniculate with the articulation between the eighteenth and nineteenth segments; the six preceding are swollen, and the five following more or less united into two segments. The outer ramus of the second pair of antennae is longer than the in. ner, composed of seven segments, the last segment longest of all and armed with very long apical setae; the setae attached to the preceding segments are short and nearly equal. The second pair of maxillae are short and thick; the third pair are elongate, turned forward, of seven segments, and furnished with short setae. The eight anterior swimming feet are biramose, the inner ramus of the first pair of two segments, and of the following pairs of three segments; the feet of the last pair, different from the others, are of five segments, with the second segment arm on the inner side with a small attendate for rudiment of an inner ramus; in the female they are short, equal to each other, the last segment very short and rudimentary, the penultimate always produced into a strong hook, curved inward; the right foot of the male is subcheliform, with the last segment formed into a very long movable hook. The eye is single. 
appendicibus tentaculiformibus 2 minimis instructus. Antennae primi paris articulis 25 apicem versus parun longitudine crescentibus compositae; dextra maris articulatione inter articulum 18-mum et 19-mum geniculans, antecedentibus 6-tumidis, sequentibus 5 in 2 modo confluentibus articnlos. Ramus antennarum 2-di paris exterior interiore longior 7 -articulatus, articulo ultimo omnium maximo setisque longissimis apicalibus instructo; setae articulis antecedentibus inhaerentes breves et fere equales. Maxillae 2-di paris breves et crassae; 3-tii paris elongatae et antice vergentes 7 -articulatae setisque brevibus obsitae. Pedes anteriores $S$ biramosi natatorii, ramo interiore in 1-mo pari 2-, in sequentibus 3 -articulato pedes ultimi paris ceteris dissiniles 5-articulati, articulo 2-do intus appendice parva vel rudintento rami interioris instructo; in femina breves inter se equales, articulo ultimo perbrevi et rudimentari, penultimo sine tine in unguem validum introrsum curvatum exeunte; dexter maris subcheliformis, articulo ultimo in nuguem mobilem longissimum conformato. Oculus unicus."

\section{ANALYTICAL KEYS.}

Artificial keys are always unsitiserory, and yet they seem necessary in order to help one to a determination of species. In the following keys an attempt has been made to indicate the groupings of species by a few salient points. The result is not what conld be wished, but it is looped that it will be of assistance, especially to those who are not familiar with the classification of the genus. The synopses of DeGuerne and Richard are by all odds the most satisfactory of those hitherto published; accordingly these analyses are based on their work. No attempt has been made to carry the analysis of the characteristics of the females far enough to determine all the species, for it is impossible, in some cases, to separate the females of related species. A final determination can he made only when one has the male forms. 
ANALYTICAL KEY TO THF NOIRTI AMEKICAN SPECIES OF DIAPTOMUS BASED ON THE CHARACTERS OF THN MALE.

Antepenultimate segment of the male right antenna with-

out a dicturet appendage,

Antepenultimate segment slightly produced at the distal end into a blunt point, first segment of right exopodite with marked quadrangular hy.

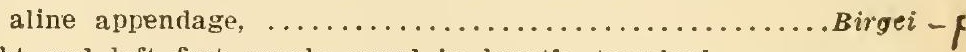

Right and left feet nearly equal in length, terminal hook of right foot symmetrical, $\ldots \ldots \ldots \ldots \ldots \ldots$ oregonensis $-p$

Left foot shorter than right,

Left foot reaching beyond first segment of the exopłodite,

Terminal hook of right foot uniangular, right endopodite equal in length to first segment

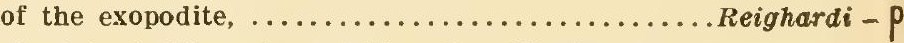

Terminal hook biangular, right endopodite large, longer than first segment of the exopodite, $\ldots \ldots \ldots \ldots \ldots \ldots \ldots \ldots \ldots \ldots \ldots \ldots \ldots \ldots \ldots \ldots$ mississippiensis $-p$

Left foot reaching end of first segment of the exopodite,

Inner process of the terminal segment of the left exopodite falciform, no hyaline appendage of first segment of right exopodite. ..........pallidus $-p$

Inner process of terminal segment of left exopodite digitiform, a hyaline appendage on internal distal angie of first segment of right exopodite, $\ldots \ldots \ldots \ldots \ldots \ldots \ldots \ldots \ldots \ldots \ldots$ Tyrelli $-p$.

Antepenultimate segment of male right antenna with hyaline lamella,

Hyaline lamella broad, extending beyond the end of the segment, second basal segment of the right exopodite armed on the posterior surtace with a small hook, leptopus - p

Hyaline lamella narrow, extending beyond the end of the segment slightly, if at all, first basal segment armed with a hook equal in length to the first

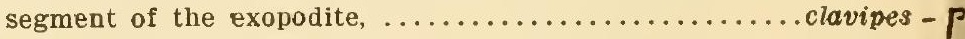
Antepenultimate segment of the right antenna bears

a slender straight process,

This process is much shorter than the penultimate segment,

Right endopodite rudimentary,

Lateral spine of the second segment of the right exopodite is terminal, Lintoni-p Lateral spine of the second segment of the ex- 
opodite is near the proximal end, the anten-

nal process is dentate on the outer margin, ....... Trybomi $-p, 466$.

Right endopodite about equals in length the first

segment of the exopodite, lateral spine median,.......Judayi $-p .464$.

The process of the antepenultimate segment of the right antenna nearly equals or equals the penultimate segment,

The right endopodite equals in length the first segment of the exopodite, spines of the first basal segment large, .........................

The right endopodite exceeds the length of the first segment of the exopodite, spines of the

The process of the antepenultimate segment of the antenna exceeds in length the penultimate segment,

Large. Lateral spine of the second segment of the male exopodite is terminal or nearly so,

The antennal appendage only slightly longer than the penultimate segment, anten'nae equal in length to cephalothorax, ..................... Antennal appendage exceeding in length the ultimate segment, antenrae reaching the furca, .....Wardi $-p, 433$.

Small. The lateral spine of the second segment of the right exopodite is on the proximal half of the segment, the antennae reach beyond the furca,

Lateral spine of the second segment of the right exopodite short, right endopodite rudimentary, ....minutus $-p .426$. Lateral spine long, right endopodite equals in length the first segment of the exopodite, ........Ashlandi $-p .429$. The antepenultimate segment of the right antenna bears

a curved process,

The appendage equals or exceeds in length the penultimate segment,

The appendage about equals in length the last two segments, the second basal segment of the right foot is dilated on the inner margin, the endopodites are two-segmented, ................. Eiseni $-p, 481$.

The appendage slightly exceeds in length the penultimate segment, seciond basal segment of the right foot not dilated on the inner margin, the left endopodite one-segmented, ............... franciscanus $-p .418$.

The appendage is shorter than the penultimate segment,

One cI both terminal processes of the last segment of the left exopodite are distinctly falciform, 
The right eadopodite is small, shorter than the first segment of the exopodite,

Terminal segment of the right exopodite is elongate,

Right endopodite rudimentary, left endopodite 2-segmented, spatulate in form, ....spatulocrenatus $-p .42$

Terminal segment of right exopodite much the broadest at the distal end, lateral spine nearly terminal and straight, left endopodite elongate. ............... conipedatus $-p .4$

Torminal hook of right exopodite falciform, lateral spine at the distal thild of the segment, second basal segment of the right foot broad at the distal end with process at the external distal

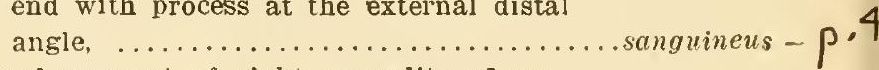

Terminal segment of right exopolite of usual length,

Lateral spine terminal, Inner surface of left endiopodite rugose, a very large species, .................... Segments of right foot short and broad. terminal hook long and strongly curved, lateral spine long and

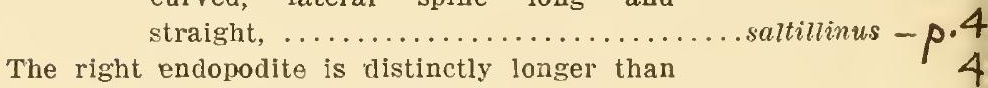

the first segment of the exopodite,

The first segment of the right exopodite las an oblique ridge on its dorsal surface.

The first segment of the right exopodite has

a transverse ridge, the lateral spine of the terminal segment is about one-half as long as the segment, ................ asymmetricus $-p \cdot 4^{\prime}$

The first segment of the right exopodite has two curved processes 'on its dorsal surface, the lateral spine of the terminal segment equals or exceels in length the segment,

ith first segment of the right exopodite does not have a transverse ridge on the dorsal surface,

The lateral spine of the terminal segment of the right exopodite is terminal, the endopodites are distinctly two-segmented,

The lateral spine is situated on the distal . dorsulis $-p .4$ third of the terminal segment of the right exopodite, the right endopodite is indis- 
tinctly two-segmented, the left one-seg-

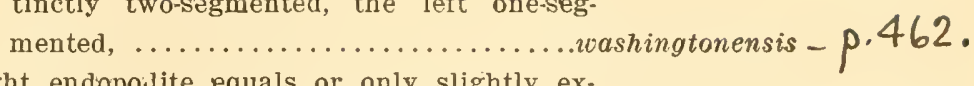

The right endopolite equals or only slightly ex-

ceeds the first segment of the exopodite,

The terminal segment of the right exopodite

has a transverse ridge on its dorsal sur-

face, the lateral spine exceeds in length

the segment, ...................

The terminal segment of the right exopodite

does not have an oblique ridge on its dorsal

surface, the lateral spine is short, about one-

half the length of the segment, .........novamexicanus $-p, 483$.

The terminal processes of the left exopodite are

digitiform, the right endopodite shorter than

the first segment of the exopodite,

The right endopodite triangular in form, first segment of the exopodite without hyaline appendage, $\ldots \ldots \ldots \ldots \ldots \ldots \ldots \ldots \ldots \ldots \ldots \ldots \ldots \ldots \ldots \ldots$ nudus $-p .460$.

The first segment of the right exopodite with hyaline appendage,

Appendage at the inner distal angle, endopodite about equals the first segment of the

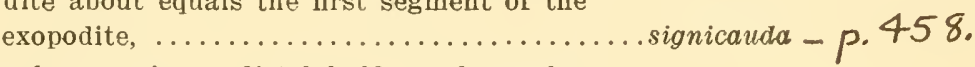

Appendage on inner distal half. quadrangular in form, encopodite much shorter than the first segment of the exopodite, ............ siciloides $-p .438$.

The first segment of the right exopodite with a transverse ridge, second segment with oblique ridge and hyaline process near the outer margin, $\ldots \ldots \ldots \ldots \ldots \ldots \ldots \ldots \ldots \ldots$ purpureus $-p .476$.

ANALYTICAL KEY TO THE NORTI AMERICAN SPECIES OF DIAPTO-

\section{MUS BASED ON THE CHARACTERS OF THE FEMALE.}

The endopodites of the fifth feet are shorter than the

first segments of the exopodites,

The first antennae do not reach the end of the furca,

The endopodites are one-segmented,

The exopodites are two-segmented, the fifth cephalothoracic segment has a dorsal process, the first abdominal segment is asymmetrical, its distal end being expanded to the right, ................ Tryoomi

The exopodites are three-segmented, there is no dorsal process, the abdomen is symmetrical, .....purpureus

The fifth cephalothoracic segment has a dorsal process, the first abdominal segment is asym- 
metrical, its distal end being expanded to the rights, Tryboms

The endopodites are two-segmented,

Terminal spines of endopodite fully as long as the endopodite, a large species, ............. slagnalis

Terminal spines of endopodite slort, a moderate sized species, ................................

The first antennae equal or exceed the lengtl of the

whole body including the furca,

The endopodite is rudimientary, ...........................

The endopodite equals in length about one-half the first segment of the exopodite,

Fifth cephalothoracic segment with dorsal process, endopodite one-segmented, .................tillinus

Fifth cephalothoracic segment with dorsal process, endopodite crommonly two-segmented, .. albuguerquensis

The endopodite exceeds in length one-half the first segment of the exopodite,

The fifth cephalothoracic segment is armed with two dorsal processes, ................................

The first segment of the abdomen lias a prominent swelling on the right side..............symmetricus

The endopodite equals or exceeds in length the first segment of the exopodite,

There is a digitiform process on the right posterio: border of the first abdominal segment. This process is variable in length, typically, in signicauda. extending far beyond the second segment, signicauda, nudus, vashingtonensis, Judayi (These species can be satisfactorily separated only by the characteristics of the male. Generally the abdominal process is much more pronounced in signicauda. The lateral projections of the abdomen are strongest in Judayi, less pronounced in nudus and about equally prominent in washingtonensis and signicauda).

The first abdominal segment bears no process on its

right hand posterior margin.

The lateral spines of the abdomen are either absent or very minute,

The exopodite is distinctly three-segmented,

Antennae equal to cephalothorax, a very

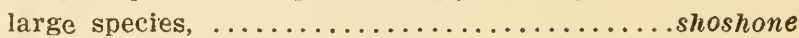

Antennae reach to furca, ....................

The exopodite is two-segmented, the abdomen elongated,

The abdomen is very much elongated, the lateral swelling of the first segment very

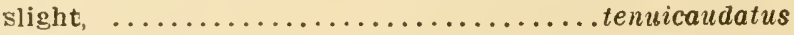


Lateral swelling of first abdominal segment distinct, sicilis, Ashlandi, oregonensis, pallidus, Reighardi, mississippiensis, Lintoni, spatulocrenatus.

(These species cannot be satisfactorily separrated by the characteristics of the female, although the limits of size will help somewhat.)

The lateral spines of the abdomen are distinct, The exopodite is distinctlit three-segmented, the endopodite is two-segmented, ..................

The exopodite is two-segmented, the endopodite one-segmented, the second segment of the exopodite has three spines, conipedatus, clavipes, Tyrelli, leptopus.

(These cannot be separated by the characteristics of the female.)

The second segment of the exopodite has two spines, siciloides, sanguineus, Birgei, novamexicanus.

DIAPTOMUS OREgonexsis Lilljeborg. Plate $\mathrm{XY}$. figs. $1,4,7$.

1889. Diaptomus oregonensis DeGnerne and Richard, p. 53; pl. II, fig. 5; pl. III, fig. 8.

1593. Diaptomus oregonensis Marsh, p. 200 ; pl. IV, figs. 4, 5. 1895. Diaptomus oregonensis Marsh, p. 8; pl. VII, fig. 5.

1895. Diaptonus oregonensis Herrick and Tumer, p. 72 ; pl. IV, figs. 7-12; pl. IX, fig. 3.

1897. Diaptomus oregonensis Schacnt, p. 151; pl. XXIX, figs. 1 and 2.

1906. Diaptomus pygmaeus Pearse, p. 244; figs. 1, 2 and 3.

Of medium size. Cephalothorax widest at the middle. The first segment of the cephalothorax exceeds in length the three following segments. The last segment is slightly produced laterally and amed with two minute spines.

The first segment of the female abdomen equals in length the rest of the abdomen. It is slightly expanded laterally, and sometimes bears two very minute lateral spines; these, however, are not always present. The second segment is shori : than the third, and the third shorter than the furcal rami. The length of the furcal rami is twice their width; they are finely ciliate on the inner margin. 
The antennae are 25-segmented and nearly reach the ends of the furcal setae. The right male antenna is swollen anterior to the geniculating joint; the antepenultimate segment has no special armature.

The first basal segments of the female fifth feet have the spines of the posterior surface of moderate size. The latera! hair of the second basal segment is of moderate size. The first segment of the exopodite is twice as long as wide. The hook of the second segment is slender and rather slightly curved. It is finely dentieulate on the inner margin. The third segment is ordinarily represented by two spines, of which the outer is the longer. In some eases, however, the inner spine arises from a small segment, which represents the third segment of the exopodite. The endopodite sligbtly exceeds in length the first segment of the exopodite. It is obtusely pointed, is setose at the tip, and armed with two rather long terminal spines.

The first basal segments of the male fifth feet liave the spines of the posterior surface of moderate size. The second basal segment is a little less than twice as long as wide. The lateral hair is situated at the beginning of the distal third. The first segment of the exopodite is trapezoidal in form, its length and breadth are about equal, and it is somewhat produced on th 3 distal exterior angle. The second segment is twice as long as its width and is slightly eurved on the exterior margin. On the posterior surface near the internal margin it bears a smaii spine; this is situated at the end of the proximal third of the segment. The lateral spine is situated near the end of the segment; it is about two-1hirds as long as the segment, is slightly eurved, and minutely denticulate on the inner margin. The terminal hook is slender, regularly eurved, and nearly equals in length the whole of the right foot. It is finely denticulate on the inner margin. The endopodite is one-segmented, rather stout, and exceets in length the first segment of tire exopodite. It is setose at the tip. The left foot equals in length the right. The second basal segment is in form liko the corresponding segment of the right foot, but is somewhat sincller. There is a slight projection on its inner margin. The lateral hair is situated at the beginning of the distal thirr. The first segment of the exopodite is twice as long as wide. 
The outer margin is conves, the inner simuate and setose. The socond segment is produced into two finger-like processes, one exterior and one interior. The exterior one is finely denticulate on the inner margin. The interior process bears a small process on its base which projects inwards. The inner surface of the segment is setose.

Length of female, $1.5 \mathrm{~mm}$. Length of male, $1.4 \mathrm{~mm}$. These are the figures of Lilljeborg. There is considerable variation in the length of specimens from varions localities.

This is one of the most widely distributed of the North American species. The type specimens were from Portland, Oregon. It is by far the most common species in the lakes of Wisconsin and Michigan, and occurs, though not in great num. bers, in the Great Lakes. It is found in Iowa, northern Illinois and northern Indiana, in Minnesota, and I have specimens from Kinistino, Northwest Territory. No extensive collections have been made in the eastern states, but it is found in eastem Massachusetts, and I think it probable that this species is distributed all orer North Ameriea north of the latitude of northern Illinois. In sonthern Illinois and in the sonthern states its place seens to be taken by $D$. pallidus.

It is rather remarkable that a species of such wide distribution should show so little variability.

I have not seen specimens of Pearec's pygmucus. but I have gone orer his description and figures rery carefully, and I see no reason to separate it from oregonensis. The only possible points of difference which I can see, are the form of the hook of the exopodite of the male right fifth foot, the form of the endopodite of the left fifth foot of the male, and the form of the female abdomen. Pearse states in his description that the hook is curved somewhat "sharply." His figure, however, shows no sharper curvature than would be true of oregonensis. The endopodite of the left fifth foot of the male is more pointed than in typical oregonensis, but the form of this segment varies, and frequently is as sharp as in his figure. Apparently, from his figure, the abdomen of the female is somewhat broader than in the type. These differences, howerer, if they are recognizable differences, conld hardly be considered more than varietal. 
DIAPTOMUŚ BEIGHARDI Mar'sh.

Plate XY, figs. 2, 6, 9.

1895. Diaptomus Reighardi Marsh, p. 9; pl. I, figs. 1-4. 1897. Diaptomus Reighardi Sehacht, p. 169 ; pl. XXVIII, fig. 1.

Of moderate size. The first cephalothoracic segment nearly equals in length the rest of the cephalothorax; the suture of this segment is very distinct. The last cephalothoracic segment is armed on each side with a minute spine.

The first segment of the female abdomen is elongated, nearly equaling in length the remainder of the abdomen and the furea. It is dilated laterally and in front. The lateral dilatations are slight, and are armed on each side with a minute spine. The second segment is abont one-third shorter than the third. The third segment is slightly shorter than the fureal rami. The furcal rami are ciliate on the inner margin.

The antennae are 25-segmented and reach to the end of the furea. The right male antenna is swollen anterior to the genicnlating joint; the antepenultimate segment has no appendage.

The spines of the posterior surface of the first basal segments of the female fifth feet are very small. The first segment of the exopodite is twice as long as wide. The second segment is prolonged into s sharp hook which is denticulate on the inner margin. The third segment is represented by two spines. The endopodite is one-segmented, slightly longer than the first segment of the exopodite, is setose at tip, and armed with two rather long spines.

The spines of the first basal segments of the male fifth feet are moderately prominent. The second basal segnent of the right foot is about one-half longer than broad. The lateral hair is sitnated at abont two-thirds of its length. The length of the first segment of the exopodite is about equal to its width. It bears a slight fold on its posterior surface near the distal end. The second segment is more than twice as long as wide, 
and concave on the inner margin. At about one-third of its length is a small spine near the inner margin. The lateral spine, situated at the beginning of the distal third of the segment, is slightly curved, and finely denticulate on the inner margin. The terminal hook is slender, and equal in length to the whole right foot. At slightly less than half its length there is an abrupt angle. Distad of the angle, the inner margin of the hook is denticulate. The endopodite is one-sergmented, rounded at tip, and equal in length to the first segnient of the exopodite. The left fifth foot of the male reaches a little beyond the middle of the second segment of the right exopodite. The second basal segment is a little longer than wide, and somewhat shorter than the corresponding segment of the right foot. The lateral hair is situated at the beginning of the distal third. The first segment of the exopodite is about as long as wide, its distal end considerably narrower than the proximal. The inner margin is strongly convex and setose. The second segment is about twice as long as the first, and is armed at the tip with two finger-like processes; the onter of these processes is much the larger, and is armed on its inner surface with a minute setose pad. The inner process is separated from the main part of the segment by a suture. The endopodite is slender, twice as long as the first segment of the exopodite, and setose at the tip.

Length of female, $1.1395 \mathrm{~mm}$. Length of male, $1.0248 \mathrm{~mm}$.

This species was found in collections made in connection with the scientific work of the Michigan Fish Commission in Intermediate lake; and in North lake on Beaver island. It also occurred in a collection made by Dr. R. H. Ward in Crooked lake. It was associated with $D$. oregonensis, to which it is closely re. lated. It is apparently a rather narrowly localized species, for, although collections have been made quite generally in the Michigan and Wisconsin lakes, it has, so far, been found only in these three localities. 
414 Wisconsin Academy of Sciences, Arts, and Letters.

daptomes Mississippiensis Marsh.

Plate XY, figs. 3, 5, 8.

1894. Diaptomus mississippiensis Marsh, p. 15; pl. I, figs. $1-3$.

1595. Diaptomus mississippiensis Herrick and Turner, p. 78; pl. XLVII, figs. 1-3.

1897. Diaptomus mississippiensis Schacht, p. 173 ; pl. XX XIII, figs. 1-4.

Of moderate size. The suture of the first cephalothoracic segment is very distinet. This segment is about equal in length to the three following. The last cephalothoracic segment is armed on each side with a minute spine.

The first abdominal segment of the female is as long as the remainder of the abdomen and the furca. It is dilated laterally and in front, and bears two lateral spines of which the right one is ordinarily somewhat the larger. The second segment is somewhat shorter than the third, and the third and the furea are about equal in length. The length of the fureal rami considerably exceeds their width, and they are ciliate on the inner margin. The furcal setae are short and stout.

The antennae are 25 -segmented and reach beyond the furca. The right antenna of the male is much swollen anterior to the geniculating joint; the antepenultimate segment has no appendage.

The female fifth feet are rather short and stout. The spines of the first basal segments are small. The lateral hairs of the seeond basal segments are moderately long. The length of the first segment of the exopodite is less than twice its width. The hook of the second segment is short, acuminate and slightly curved. It is denticulate on the inner margin. The third segment is represented by two spines, of which the imner is the longer. The endopodite is ono-segmented and slightly exceeds the length of the first segment of the exopodite. It is setose at tip and bears two terminal spines. 
In the fifth feet of the male the spines of the first basal seg. ment are rather large. The second basal segment of the right foot is broader than long and much swollen on the inner side. The lateral hair is at the beginning of the distal third. The first segment of the exopodite is trapezoidal, and as broad as long. The second segment is stout, its length exceeding its breadth by abont one-half. At the middle of its inner margin is a small spine. The lateral spine is of moderate length, nearly straight, and denticulate on the immer margin. It is situated at the distal angle of the segment. The terminal hook has the symmetry of the curve broken by two rather abrupt angles; its imner margin is finely denticulate. The endopodite is stout and somewhat spindle-shaped. It is attached to the side of the second basal segment. It is setose at the tip, and reaches nearly to the middle of the second segment of the exopodite. The second basal segment of the left fifth foot is quadrate and nearly equal in length to the corresponding segment of the right foot. The lateral hair is sitnated well towards the distal end of the segment. The first segment of the exopodite is trapezoidal, the distal end being very narrow. The second segment consists of an oval base and two elongated digitiform processes. The basal part is setose on the inner margin. Of the terminal processes, the posterior one is the longer. The anterior one is enlarged and denticulate at tip and is separater from the segment by a distinct joint. The endopodite is one-segmented and nearly equal in length to the exopodite. The whole foot reaches to the middle of the second segment of the exopodite of the right foot.

Length of female, $1.2 \mathrm{~mm}$. Length of male, $1.1 \mathrm{~mm}$.

The original description was from material sent by Professor Birge and obtained in Jackson, Mississippi. I have since found it in collections made by Professor Birge in Guzman and Slidell, Lonisiana, and Schacht reports it from lakes in Florida. 
DIAPTOMUS PALLIDES Herrick.

$$
\text { Plate XVI, figs. 1, 2, :. }
$$

1879. Diaptomus pallidus Herrick, p. 91 ; pl. II, figs. a-d.

1883. Diaptomus pallidus Herrick, p. 383; pl. VII, figs. 1-6. 1884. Diaptomus pallidus Herrick, p. 142 ; pl. Q, fig. 17.

1889. Diaptomus pallidus DeGuerue and Richard, p. 62 ; fig. 34.

1893. Diaptomus pallidus Marsh, p. 196 ; pl. III, figs 6, 7, 9. 1895. Diaptomus pallidus Merrick and Tnmer, p. $73 ; \mathrm{pl}$. IV, figs. $1-6$; pl. V, fig. 10 ; pl. XIII, fig. 17.

1897. Diaptomus pallidus Schacht, p. 144; pl. XXVII, fig. 3. 1905. Diaptomus pallidus Pearse, p. 147.

A slender species of medium size. First cephalothoracic segment considerably longer than the three following; the last cephalothoracic segment hears two small lateral spines.

The first abdominal segment of the female nearly equals in length the rest of the abdomen, is slightly dilated laterally, and bears two minute lateral spines. 'The second segment is slightly shorter than the third, and the third slightly shorter than the furcal rami. The furcal rami are ciliate on the inner inargin.

The antennae are 25 -segmented and reach slightly beyond the end of the furcal rami. The right antenna of the male is swollen anterior to the geniculating joint, and without special armature.

The female fifth feet are short and stout, the spines of the first basal segments small. The lateral hairs of the second basal segments are rather long. The exopodite is composed of two segments, the third segment being represegnted by two spines. The second segment is prolonged into a rather long hook, and serrulate on the inner margin. The endopodite is slightly longer than the first segment of the exopodite; the tip is setose, and armed with two rather long spines.

In the male fifth foot the spines of the posterior surface of the first basal segments are sinall. The second basal segment 
of the right foot is twice as long as broad, and the rather long lateral hair is situated at about two-thirds of its length. The first segment of the exopodite is longer than broad. The seeond segment is twice as long as the first, and bears upon its inner margin at the end of the proximal third a small spine. The outer distal angle of the segment is truncated, and the laturit spine, which is slender and slightly eurved, is situated at the beginning of this trumcation. The terminal spine is slender, curved, and slightly angular, and about once and a half the length of the first segment of the exopodite. It is denticulate on the inner margin. The right endopodite is slender, of one segment, pointed at the tip, with minute terminal setae, and equal in length to the first segment of the exopodite.

The left male fifth foot reaches abont one-third the length of the second segment of the right exopodite, althongh its length is somewhat variable. The second basal segment is quadrate and longer than broad. The lateral hair is situated at about three-fourths of its length. The first segment of the exopodite equals in length the corresponding segment of the right foot; the distal end is about one-half the width of the proxinal. The seeond segment is one-half as long as the first. It is armed with an outer finger-shaped process which has a small pad on its inner margin, and an inner slender faleiform proeess which curves over the tip of the segment. This falciform process is armed with a blunt spine on its inner margin. I fail to verify the armature as deseribed by Herriek ('95, p. 73.) The endopodite is slender, pointed, with minute terminal setae, and is equal in length to the first segment of the exopodite.

Length of female, $1.18 \mathrm{~mm}$. Length of male, $1.043 \mathrm{~mm}$. These lengths are averages from speeimens from St. Louis. They are larger than I had obtained from Wisconsin specimens, but not as large as the figures given by Herriek.

Herrick's original deseription was of specimens found in Minnesota. He afterwards reported a species "like pallidus" in Alabama. (Herrick, '8 7 , p. 11.) In his final report he 27-S. \& A. 
speaks of it as in the entire Mississippi valley, but without specifying definite locations.

Schaclit ( 97, p. 146) says it is extremely abundant near Havana, Ill. I have foumd it in only one locality in Wisconsin,- Heart lake near Marquette. I have also found it in collections from Elk lake, Clay county, Iowa. From the southern states I have found it from Missouri, Tennessee, Arkansas, Lonisiana and Texas. It occurs, too, in Lake Minnequa in Pueblo, Colorado, and in eastem Nebraska, and the presumption is that it occurs at intermediate points between the Rocky monntain region and the observed stations farther cast. So it would appear that it is not only found throughout the Mississippi valler, but that it is pretty well confined to that vallev. and much more abundant in the middle and southern part of the region.

Diaptomes Fraxciscanus Lilljeborg.

Plate XXVI, figs. 7, 11. Plate XXVII, figs. 1, 2.

1889. Diaptomus franciscanus DeGneme and Richard, p. 48; pl. I, tigs. 12, 13, 34 ; pl. III, fig. 23.

1895. Diaptomus franciscanus Herrick and Turner, p 5s; pl. VIII, figs. 12 and 16.

1897. Diaptomus franciscanus Schacht, p. 160; pl. XXX, figs. $1-4$.

Rather large. Cephalothorax widest at the midlle, the last two segments confluent sabove. The lateral lobes, seen from above, are short and oltuse posteriorly, and armed on each side with two small spines. The first segment of the abdomen is about equal in length to the rest of the aldomen, is moderately dilated in front, rounded at the sides, bears two small lateral spines, but lacks lateral processes. The indications of a joint-an imperfect suture-remain long after maturity in the posterior part of this segment. The second abdominal segment is much shorter than the third, its test more delicate and easily pushed together. The fureal rami are short, their length 
to their breadth as one and one-half to one; they are ciliste on both imer and onter margins.

The first pair of antemnae in the female are 25-segmented, and reach abont to the furca. The antepenultimate scgment of the right antenna of the male hears an mnguiform process, slightly longer than the penultimate segment.

In the female fifth foot, the exopodite is three-segmented. The first segment is somewhat elongate, its length being nearly three times its width. The second segment is prolonged into the eustomary look. The hook is arenate, denticulate on the inner margin, the last troth being the hargest. The segment bears a small spine at it onter distal angle. The thind segment is small but distinct, and bear's two small spines. The endopodite is one-segmented, about eqpal in length to the first segment of the exopodite, and bears at the tip two musually long spines which are ciliate at base.

In the male, the second basal segment of the right foot is quadrate, longer than wide, and bears the lateral seta a little beyond the middle. The first segment of the exopodite is quadrate and short, heing only about one-half the length of the second basal segment. The second segment is rectangular, rather less than twice the length of the first; the lateral spine is situated at the distal angle, and abont midway of the inner margin there is a minute spine. The terminal hook is long, equaling the whole right foot exchnsive of the first basal segment, is sigmoid, and slender towards the apex. The embpodite is small, harely reaching the middle of the second segment of the exopodite, is imperfectly two-segmented or onescgmenterl, and hears a spine at the apex.

The left fifth foot of the male reaches abont to the middle of the second segment of the exopodite of the right fout. The sccond basal segment is longer than broad, shorter than the corresponding segment of the right foot, is concave on the onter margin and convex on the inner; the lateral hair is situated at about three-fourths of its length. The first segment of the exppodite is twice as long as wide, nearly as long as the second basal segment. The second segment is about equal in length 
to the first, is almost triangular, and thinner on the inner margin. The outer part of this segment is thicker, has a short spine in the middle, and ends in a short and obtuse process. The oblique apical margin of the inner surface has three small incisions. The inner margin of this segment is finely ciliate. The endopodite is one or two-segmented, slender, attenuate towards the apex, and reaches to about the middle of the second segment of the exopodite.

Length of female, $2.3 \mathrm{~mm}$. Length of male, $2 \mathrm{~mm}$.

Found in the neighborliood of San Francisco.

The above is the description of DeGuerne and Richard with some slight additions. The species has thns far been found only in the original locality.

DIAPTOMUS BAKERI sp. nOv.

Plate XVI, figs. 4, 5, 6, 9.

A small species. The first cephalothoracic segment is as long as the three following, the second, third and fourth being about equal in length. The last cephalothoracic segment is armed with two minute spines on each lateral lobe.

The first segment of the female abdomen equals in length the rest of the abdomen, including the fureal rami. It is broad, dilated in front and laterally, with two small lateral spines about midway of its length. The second segment is very short. The width of the third segment is greater than its length. The furcal rami are about equal in length to the third segment, and are ciliate on the inner margin.

The antennae are 25-segmented and barely reach the end of the furcal rami. The right antenna of the male is much swollen anterior to the geniculating joint. The antepenultimate segment bears a hook-shaped process which is fully half as long as the penultimate segment.

The first basal segments of the female fifth feet are armed with rather small spines. The lateral hairs of the second basal segments are short. The exopodite consists of three segments. The second segment is prolonged into a hook which is quite 
strongly recurved. The hook is denticulate on its inner margin, the distal denticulations being unusually large. The outer angle of the second segment has a small spine. The third segment is short, but distinct, and armed with two spines. The endopodite equals in length the first segment of the exopodite. It is two-segmented, and the distal segment is armed at the tip with three spines, one rather stout and plumose, the other two long and slender.

The spines of the first basal segments of the male fifth feet are rather small. The second basal segment of the right foot is quadrate, its length being to its width as three to two. The lateral hair is near the middle but on the distal portion. The first segment of the exopodite is very short, its width being about twice its length. The outer margin is prolonged distally, and the inner margin, on the posterior face, bears a hyaine lamella which is much wider at the distal end of the segment. The second segment of the exopodite is twice as long as broad and is quadrate in form. At abont a third of its length, on the posterior face, nearer the inner margin, is a small spine. The lateral spine is on the outer distal angle, of medium length, and nearly straight. The terminal hook is as long as the whole right foot exclusive of the first basal segment, is slender, and with a marked angle about midway of its length. The right endopodite is two-segmented, extends something less than onehalf the length of the second segment of the exopodite, and is tipped with two small, blunt spines. The second basal segment of the left foot is quadrate, about two-thirds the length of the corresponding segment of the right foot. The lateral hair is near the distal angle. The first segment of the exopodite is long and slender, being nearly four times as long as broad. It is trapezoidal in form, and bears on its inner margin a rounded hyaline projection. The second segment of the exopodite is very slender, and bears two finger-like processes. Near the base on the inner margin is a prominent ciliated pad. The endopodite is slender, two-segmented, reaches about midway of the length of the second segment of the exopodite, and is terminated by two minute spines. 
Lengtli of female, $1.27 \mathrm{~mm}$. Length of male, $1.124 \mathrm{~mm}$.

This species was found in material collected hy Professor C. F. Baker in Lake Lagunita, Palo Alto, California.

This form is closely related to $D$. franciscanus Lillj. The general form of the male fifth feet is the same, but there are marked differences in the exopodite of the left foot. The projection of the antepenultimate segment of the right male antenna is shorter. The endopodite of the female fifth foot is two-segmented, while it is composed of a single semment in $D$. franciscanus. The endopodite in D. Bakeri is armed with three terminal spines, while there are only two in $D$. franciscanus. The very close relationship, however, is shown in that in both species the exopodite is three-segmented, and both have the peculiar denticulation of the inner margin of the second segment with the larger teeth towards the distal end.

DIAPTOMUS TENUICAUDATUS sp. not.

\section{Plate XVI, figs. 7, 8. Plate XVII, figs. 2, 3.}

The first cephalothoracic segment is nearly as long as the rest of the eephalothorax. The last segment hears two minute lateral spines.

The abdomen of the female is musually long and slender. The first segment is considerably longer than the next two, and is somewhat enlarged in front and laterally, but has no lateral spines. The second segment is slightly longer than the third, and the fureal rami about equal in length to the second segment. The length of the furcal rami is about three times their breadth.

The antemnae hardly. reach the end of the furca. The right antenna of the male is swollen anterior to the genieulating joint, and the antepenultimate segment hears a straight process, which equals in length the penultimate segment.

The first basal segments of the female fifth fect are ainecl with the customary spines. The lateral hairs of the second basal segnents are rather long. The exopodite is composed of 
two segments, the third segment being represented by two spines. The second segment is prolonged into the customary hook, which is very finely denticulate on the imer margin. The endopodite slightly exceeds in length the first segment of the exopodite, is delicately hairy at the tip, and is armed witl two rather short terminal spines.

The first basal segments of the male fifth feet are armed with large spines. The second basal segments are rudely trapezoidal in form with the inner margins emred, and with the lateral hairs situated at about one-third the length of the segments from the distal ends; the segment of the right foot is considerably larger than that of the left. The first segment of the exopodite is quadrate, its length and breadth being nearly equal. It bears upon the outer distal angle a rounded hyaline lamella, and another rounded lyaline lamella projects on the posterior surface from the distal part of the segment; this lamella projeets slightly over the seeond segurent of the exopodite. The second segment is much shorter than the combined length of the first segment and the second basal segment. The lateral spine is situated at about three-fourths its length. The terminal hook is falciform, and about a third longer than the two segments of the exopodite. The endopodite is slender, hairy at the tip, and slightly exceeds in length the first segment of the exopodite. The two segments of the left exopodite are rudely oval in form, about equal in length. The inner margin of the terminal segment and the distal third of the inner margin of the first segment are ciliate. The seeond segment bears two short fingerlike processes. The left endopodite is slender, reaching nearly half the length of the second segment, and is indistinctly twosegmented.

Length of male, $1.195 \mathrm{~mm}$. Not enough mature females were secured to get an average of lengths.

This species was found in material eollected by Mr. Russeil T. Congdon in Glen lake, Saskatehewan.

The noticeable peenliarities which distinguish this from other forms are the elongated female abdomen, without lateral spines, and the hyaline lamellae of the first segment of the exopoditc of the right male fifth foot. 
424 Wisconsin Academy of Sciences, Arts, and Letters.

Diaptomes sicrlis Forbes.

Plate XVII, figs. 1, 4, 5, 9.

1S82. Diuptomus sicilis Forbes, p. 645; pl. VIII, figs. 9, 20.

18S4. Diaptromus pallidus var. sicilis Herrick, p. 142; pl. Q, fig. 18 .

1S59. Diaptomus sicilis DeGuerne and Richard, p. 23 ; figs. 13, 14; pl. II, fig. 18 .

1891. Diaptomus sicitis Forbes, p. 702 ; pl. I, fig. 6.

1893. Diaptomus sicilis Marsh, p. 197; pl. III, figs. S, 10.

1595. Diaptomus sicilis Herrick and Turner, p. $60 ;$ pl. Y, figs. $1-7$; pl. XIII, fig. 18 .

1595. Diaptonus sicitis Marsh, p. 7 ; pl. VII, figs. 1, 11.

1S97. Diaptomus sicilis Schacht, p. 122; pl. XXI, figs. 1-3.

1905. Diaplomus sicilis Pearse, p. 147.

A rather small, slender species. The suture of the first cephalothoracic segment is very distinct. This segment is somewhat shorter than the rest of the cephalothorax. The last segment is armed with a minute spine on each side.

The abdomen of the female is elongated. The first segment is shorter than the rest of the abdomen. It is moderately dilated laterally. Schacht figures small lateral spines, but I do not find them in my specimens. The second and third segments and the furcal rami are nearly equal in length. The furcal rami are more than twice as $l o n g$ as wide. The setae are long and slender.

The antennae are 25 -segmented and reach beyond the furca. The right antenna of the male is slightly swollen anterior to the geniculating joint. The antepenultimate segment bear's a slender, straight process, slightly swollen at the tip, and nearly equal in length to the penultimate segment.

The spines of the first basal sogments of the female fifth feet are small. The lateral hair of the sceond basal segment is of moderate length. The first segment of the exopodite is twice 
as loug as wide. The hook of the second segment is moderately curved, and finely denticulate on the inner margin. The third segment is represented by two spines, of which the imner is the longer. The endopodite is slender, slightly exceeding in length the first segment of the exopodite. It is setose at tip and bear's two rather long terminal spines. It is commonly composed of one segment, but sometimes has two.

The male fifth feet are of moderate length. The spines of the first basal segments are slender and rather long. The second basal segment of the right foot is longer than wide, and its inner and outer margins are convex. The lateral hair is short, and situated at the beginning of the distal fourth. The first segment of the exopodite is as long as broad, and somewhat produced at the distal outer angle. From the posterior surface near the internal distal angle extends a hyaine lamella. The second segment is more than twice as long as its width, is strongly convex on the outer margin, and slightly concave on the inner. The distal end is about one-half as wide as the proximal. The lateral spine is slightly curved, about half as long as the segment and situated near the beginning of the distal third. The terminal hook is slender, falciform, symmetrically curved, somewhat less in length than the rest of the right foot. The endopodite is slender, cither one- or two-segmented, and considerably longer than the first segment of the exopodite. The second basal segment of the left foot is quadrate, slightly longer than broad, with the lateral hair situated at the beginning of the distal fourth. The first segmuent . exopodite is longer than wide, its inner surface strongly curved and setose. The second segment is twice as long as wide. The inner margin has two setose convexities, the distal one being continuous with the rounded end of the segment. This segment is terminated br two finger-like processes, the immer being shorter and more slender. The left foot reaches to about the iniddle of the second segment of the right exopodite. The endopodite is long and slender, reaching about two-thirds the length of the second segment of the exopodite. It is composed of either one or two seyments, and is setose at the tip. 
Tength of female, $1.25 \mathrm{~mm}$. Length of urale, $1.15 \mathrm{~mm}$.

In the material I have examined, the endopodites of the male fifth feet have more commonly been one-segmented. Only rarely have I found the endopodites of the female fifth feet two-segmented.

The original description was from material collected by Dr. Forbes in Lake Nichigan. It is a common limnetic species in all the Great Lakes. It occurs in Pine lake, Michigan, which has an almost direct connection with Lake Michigan. It occurs in Green lake, Wisconsin; in this lake it is a winter form. (Marsh, '97, p. 193. Marsh, '03, p. 23.) I have found it once in Tomahawk lake, Wiscomsin, and Schacht reports that Dr. Forbes found it in Lake Michigamme, Michigan, and in Yellowstone park collections. In general, it may be said that it is pretty largely confined to the large, deep lakes. It has, thus far, never been found north or south of the Great Lakes, with the exception that it has been reported by Teardsley ('02) from Seely lake, Colorado, and by Pearse ('05) from Nebraska.

Drapomis matres Lilljeborg.

Plate XVII, figs. 7, 11. Plate XVIII, figs. 1. 7.

1889. Diaptomus minutus DeGuerne and Richard (Lillj.), p. $50 ; \mathrm{pl}$. I, fige. 5. 6,$14 ;$ pl. III, fig. 25.

1891. Dicutomus minutus Marsh, p. 212.

1893. Diaptomus minutus Marsh, p. 199 ; pl. IV, figs. 1-3. 1895. Diaptomus mimutus Marsh, p. 8; pl. VII, fig. 3. 1895. Diaptomus mimutus Herrick and Turner, p. $59 ; \mathrm{pl}$. VIII, fig. 9.

1897. Diaptomus minutus Schacht, p. $156 ;$ pl. XXX, figs. 5-8.

Of small size. The greatest width of the cephalothorax is in front of the middle. The first segment equals fully onehalf the length of the whole cephalothorax. The last segment has rounded lobes which are each armed witl a minute spine.

The first segment of the female abdomen is nearly as long as the rest of the abdomen. It is slightly dilated laterally at the 
anterior part, and is armed with two very minute spines. The second segment is mmch shorter than the third, and the two sre sometimes only indistinctly separated. The furcal rami are about equal in length to the third segment: they are twice as long as broad. The setae are unusually long.

The antemue are 25-segmented, and reach beyond the end of the furca. The right antenna of the male is swollen anterior to the geniculating joint, but not markedly so; the antepenultimate segment bears a long, sleuder process, slightly curved at the end, which reaches, sometimes, almost to the end of the last segment. The setae of the swimming feet are umusually long.

The spines of the first basal segments of the female fifth feet are rather small. The latersal hair of the seeond basal segment is of moderate length. The first segment of the exopodite is slender, its length being considerably more than twice its width. The hook of the second segment is only slightly eurved, and is finely dentieulate on the immer margin. There is a short spine on the onter distal angle. The third segment is rudimentary. not completely separated from the second. It is armed with two spines, of which the imner is the longer. The endopodite is acuminate, rery small and rudimentary.

The spines of the first hasal segments of the male tifth feet are small. The second hasal segment of the right foot is quadrate, longer than broad. The lateral hair is sitnated at the begimming of the distal third. The first segment of the right exopodite is of the same form and size as the second basal segment. The seeond segnent is twice as long as the first. The lateral spine is suall and situated proximad of the middle. The terminal hook is short, thick, svmmetrically eurved, and slightly denticulate on the imnei margin. Its length is somewhat less than that of the rest of the exopodite. The endopodite is very small and rudinentary. The second basal segment of the left foot is quadrate. and much wider than long. The lateral hair is situated well towards the distal end. The first segment of the exopodite is longer than wide, its inner and outer margins are convex, and its distal cul is oniy abont one-half as wide as the proximal. It is setose on its inner margin. The second 
segment is more than twice as long as broad, its outer margin straight, and its inner with two setose convexities. It is terminated with a finger-like process and a smaller spine nearer the inner margin. The foot reaches to the end of the first segment of the right exopodite. The endopodite is slender, attenuate towards the apex, and reaches to about the middle of the second segment of the exopodite.

Length of the female, 1 to $1.1 \mathrm{~mm}$. Length of the male, hardly $1 \mathrm{~mm}$.

Lilljeborg states that the female carries only two eggs. This was not true of the Wisconsin individuals, for they commonly had as many as six. This was first described from material collected in Greenland, where it is found as far north as Disco island. It appears to be very abundant in the southern part of Greenland. It was afterwards reporterd by DeGnerne and Richard from Iceland. (DeG. and R., '92.) It is found in Newfoundland. It is perhaps the most common of the Diaptomi in the Great Lakes and Lake St. Clair. It occurs in a number of lakes in the northern part of the southern peninsula: of Michigan, but these are, for the most part, connected rather closely with the Great Lakes. In Wisconsin it is found in the following lakes: Bireh, Maple, Tomahawk, Stone, Chain o' Lakes, Elkhart, Green and Geneva; all these are of the deeper lakes of the state, although there are others, equal in depth to some of these, where it is not found. The most southern point at which the species has been found is Lake Geneva. To my surprise, I did not find it in iny collections from the Northwest Territory, but all those collections were in very shallow water. One would expect to find it all over British America, wherever the environment was favorable. I think it probable that it is distributed all over North America east of the Rocky mountains. and north of the latitude of perhaps 43 degrees. 
diaptomes ashlandi Marsh.

Plate XYII, figs. 6, S, 10.

1893. Diaptomus Ashlandi Marsh, p. 198 ; pl. III, figs. 11-13. 1895. Diaptomus Ashlandi Herrick and Turner, p. 60 ; pl. VI, figs. 4-6.

1895. Diaptomus Ashlandi Warsh, p. 7; pl. VII, fig. 2. 1897. Diaptomus Ashlandi Schacht, p. 166 ; pl. XXXII, figs. $1-4$.

A small, slender species. The suture of the first cephalothoracic segment is very marked. The tirst segment equals the three following in length. The last segment is armed with minute lateral spines.

The first segment of the female abdomen equals in length the rest of the abdomen. It is somewhat dilated laterally and bears two minute lateral spines. The second segment is shorter than the third, and the third and the furcal rami are about equal. The furcal rami are ciliate. The setae are very long and slender; the internal seta is much more nearly equal to the other's than is generally the case.

The antennae are 25-segmented and reach beyond the end of the furca. The right male antenna is swollen anterior to the geniculating joint, and bears on the antepenultimate segment a slender appendage, slightly enlarged at the tip, which slightly exceeds in length the penultimate segment. The form of this appendage varies somewhat, the enlarged tip not being always evident.

The spines of the first basal segments of the female fifth feet are very small. The lateral hair of the second basal segment is very long, equaling the length of the first segment of the exopodite. The first segment of the exopodite is twice as long as wide. The hook of the second segment is long and slender and slightly curved. It is finely denticulate on the inner margin. The whole second segment slightly exceeds in length the first 
segment. The third segment is represented by two spines, of which the outer is the longer. The endopodite is slender, terminating in a blunt point. It is a little longer than the first segment of the exopodite. It is setose at tip, and has two rather long terminal spines.

The spines of the first basal segments of the male tifth feet are small and acnte. The second basal segment of the right foot is twice as long as broad. The lateral hair is situated at the beginning of the distal third. The first segment of the exopodite is broader than long, the proximal end being much narrower' than the distal. 'The inner' distal angle bears a small hyaline appendage. The seeond segment equals in length the combined length of the second basal segment and the first segment of the exopodite. 'The segment is widest at the end of the proximal third, and from this point springs the lateral spine; this is rather long, acute, with a rather abrupt eurvature just above the base. The terminal hook is slender, falciform with a symmetrical curvature, and considerably exceeds in length the rest of the exopodite. It is minutely denticulate on the inner margin. 'The endopodite is slender', equaling' or exceeding in length the first segment of the exopodite. The left fifth foot extends to about the end of the first seguent of the exopodite. The second basal segment is about half the length of the corlesponding segment of the right foot. The lateral hair is long and slender, and situated at the beginning of the distal third. The first segment of the exopodite equals the second basal segment in length; its length exceeds its width by about one-half. The second segnent equals in length the first, but is much narrower; it is terminated by two small finger-like processes. Both segments of the exopodite are setose on the inner margin. The endopodite is long, slender, curved, and reaches to about the middle of the second segment of the exopodite.

Length of fenale, 0.5) 1111 . Length of male, $0.59 \mathrm{~mm}$.

The original description was from material collected by Professor Birge at Asliland, on Lake Superior. It occurs in all the Creat lakes, and I have fommd it in Michigan in Pine lake 
and Round lake at Charlevoix, which are intimately connected with Lake Michigan. I have not found it in other localities, although Schacht reports it from Indiana, Michigan, Oregon, Idaho, Washington and Yellowstone park.

diaptonus shoshoxe Forbes.

Plate XYIII, figs. $2-5$.

1893. Diaptomus shoshone Forbes, p. 251; pl. XLII, figs. $23-25$.

1595. Diaptomus shoshone Herrick and Turner; p. 61; pl. V, fig. 11.

1897. Diaptomus shoshone Schacht, p. 141; pl. XXVI, figs.

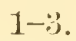

1904. Diaptomus shoshone Marsh, p. 147; pl. XXI, fig. 3; pl. XXXI, figs. 1-3.

Conspicuous becanse of its size, as it is larger than any other described American species except $D$. stagnalis Forbes.

First cephalothoracie segment indistinctly divided. The first segment equals in length the four following. The last cephalothoracic segment terminates in two minute lateral spines.

The first abdominal segment of the female is somewhat shorter than the rest of the abdomen, and is strongly dilated laterally about midway of its length. The second segment is very short. The third segment is a little less than one-half the length of the first, and is slightly shorter than the furca. The branches of the furca are ciliate on both the inner and onter margins. The furcal setae are very long, being more than three-fourths the length of the abdomen exclusive of the furca.

The antemnae about equal in length the cephalothorax. The right antemna of the male is swollen anteriorly to the geniculating joint, and bears upon the distal extremity of the antepenultimate segment a straight process. This process extends to rather less than half the length of the ultimate segment.

The first basal segments of the female fifth feet are armed 
witl rather small spines. The lateral hairs of the second basal segments are delicate. The exopodite is composed of three segments. The first segurent is stout, its length being to its breadth as $1 \%$ to 1 . The second segment is produced into the customaly hook. which is amed with short liairs on its inner margin and with a spine on the outer distal angie. 'The third segment is distinct and armed terminally with two spines, the inner being distinctl $;$ plumose. The endopodite is nearly a third longer than the first segment of the exopodite, and is indistinctly divided into two segrients. It is terminated with two rather long spines, and is armed on the immer surface of the tip with short, stout hairs.

In the male fifth feet, the spines of the first basal segments are also rather small. The second basal segment of the right foot is considerably longer than broad, and its inner and outer margins are curved. The lateral hair is situated at threefourths of its length. The first segment of the right exopodite is nearly square. The second sesment is more than twice the length of the first, and the lateral spine is situated neariy at the end of the segment. The terminal hook is falciform, quite symmotrical in its form, and equals in length the combined lengths of the basal segments and of the exopodite. It is finely denticulate in the inner margin. The endopodite is slender and somewhat longer than the first segment of the exopodite. The left fifth foot of the male extends to abont one-half the length of the second segment of the right exopodite. The lateral hair of the second basal segment is situated ver'y near the end of the segment. The first segment of the exopodite is about twice as long as broad, and armed on its inner surface with a setose pad. The second segment is rather more than half the length of the first and is amed terminally with two blunt processes. It has also two setose pads, one nearly teiminal and the other on the proximal half of the inner surface. 'The endopodite is indistinctly two-segmented, is slender, and slightly longer than the first segment of the exopodite.

Forbes, in the original description, speaks of the female abdomen as being asymmetrical. This cid not appear to be the 
case in my specimens, and in this my observations agree with those of Sehaeht.

Length of female, $2.62 \mathrm{~mm}$. Length of male, $2.595 \mathrm{~mm}$. These are the figures of Forbes. In my specimens there was more difference between the males and the females. The fomales of the Pike's Peak specimens averaged $2.9 \mathrm{~mm}$., and the males $2.495 \mathrm{~mm}$.

The original description of Forbes was from material col. lected in Lake Shoshonr. It oeenrs in many lakes in the Yellowstone park region according to him. In material sent to mo by Professor If. B. Ward, it occurred in eollections in Dead lake, Mirror lake and Lake Rocks in the Pike's Peak region.

The species is rery striking becanse of its great size. It is highly colored, the specimens from Dead lake showing very deep blues and reds; the cephalothorax was of a deep blue, while the antennae, maxillipedes and abdomen were red.

diaptomes ward Pearse.

1905. D. Wardi Pearse, pp. 148-9; pl. XIII, figs. 1-4.

"A rather large species, one-fourth to one-third as wide as long. Cephalothorax rather stout and broadest abont the middle; all the segments distinct, the first longer than the second, and these two together making abont one-half the cephalothorax. Lateral lobes of the last thoracie segment seen from above obtuse posteriorly and amed with a mimute spine at the inner and outer angles. First abdominal segment shorter than the remainder of the abdomen and broader than the following segments. Second segment of the abdomen much shorter than the third. Furcal rami short, about one and one-half times longer than broad, and eiliate on the inner margin in the male. (The number of specimens of the female was so few that no satisfactory examinations of the furea eould be made.)

"First pair of antennae reflexed extend about to the furca; composed of twenty-five articles. Antepenultimate article of right male antenna provided with a long, blunt process which surpasses the distal end of the ultimate article. 
"The outer" ramus of the fifth pair of feet in the female three-segmented, the third segment small but distinet and bearing two small spines. The basal segment bears a short, thick spine at its onter distal angle. The unguiform process of the seeond segment of this ramus is rather areuate, denticulate within and roughened on the outer margin. In addition to the two spines on the third segment, this segment has a mirute spine. The imner ramus is simple and almost equal to the first segment of the outer ramus, is eiliated at the apex, and bears two long equal spines.

"Right fifth foot of male rather robust. The busal segment is provided with a small spinous process near its inner proxinal angle. Second segment of the outer ramus short, being about one and one-fourth times as long as broad, and bearing the marginal spine at the distal angle. Terminal hook long, usually sigmoid, very minutely dentieulate on the inner margin and tapering toward the apex. Inner l'amus narrow and barely reaching the middle of the second segment of outer ramus, one-segmented and eiliate at tip. The second segment of the left male fifth foot is triangular, and ends in a short, obtuse process. The inner side is expanded, eiliated, and a strong, sharp spine projects a little below the middle of this margin. The inner ramus is simple, slender, and eiliated at the tip.

"Length of female, $2.16 \mathrm{~mm}$. Length of male, $1.60 \mathrm{~mm}$.

"This speeies resembles $D$. franciscanus Lillj. and $D$. siciiis Forbes. It differs from the former in the armature of the male antenna and the form of the male fifth feet. From the latter it differs in the structure of the female fifth feet, the size and the shape of the male fifth foot. Both these species have two-jointed inner rami in the male fifth foot, while in $D$. Wrardi they are simple.

"The speeimens upon which this deseription is based were from the collections of Prof. H. B. Ward, for whom the species is named, and were collected by Edward Butler at Spokane, Washington."

While this paper was going through the press, the publieation of Mr. Pearse, containing the above description, was re- 
ceived. It was too late to secure material to vurify the description, or to prepare figures. I have therefore taken his description verbatim. Although his description of the female is somewhat incomplete, it would appear that the species may be well founded. It falls into the tenuicaudatus group, and is closely related to $D$. shoshone Forbes. It is very possibie that a careful examination of a large number of specimens will show that it is only a variety of this species. The points of marked difference, besides that of size, are the greater length of the appendage of the antepenuitimate segment of the right male antenna, the form of the terminal segment of the left exopodite of the male fifth foot, and the two-segmented endopodite of the female fifth foot. The endopodite of the female fifth feet is only indistinctly two-segmented in shoshone, and this condition might be easily overlooked in the examination of a few individuals. The appendage of the antepenultimate segment of the right male antenna, too, may be somewhat variable. Inasmuch as Pearse gives no figure of the female abdomen, we are left in doubt in regard to its form. While it is very possible that we have here a variety of $D$. shoshone, it seems best to recognize the species for the present.

DiAptonus BIRGei Marsh.

Plate XVIII, figs. 6, 8. Plate XIX, figs. 1, 6. 1894. Diaptomus Birgei Marsh, p. 16; pl. I, figs. 4-6. 1895. Diaptomus Birgei Herrick and Turner, p. 79; pl. XLVII, figs. 4-6.

1897. Diapiomus Birgei Schacht, p. 172. 1903. Diaptomus Bircei Juday, p. 123.

Of moderate size. The first segment of the cephalothorax is nearly equal in length to the three following. The last cephalothoracic segment is armed laterally with two minute spines.

The first segment of the female abdomen is as long as the remainder of the abdomer and the furca. It is much dilated on the ventral surface, and moderately dilated saterally. The lat- 
eral dilatations are situated at the distal third of the segment, and each lobe bears two small spines. The second segment is very short, and is nearly concealed by the first. The third scorment and the furca are abont equal in length. The furcal rami are ciliate on both the inner and onter margins.

The antennae are 25-segmented and extend beyond the fureal rami. The right antenna of the male is much swollen anterior to the geniculating joint; the antepenultimate segment is produced on its distal end into a short, blunt process, which makes very nearly a right angle with the longitudinal axis of the segment.

In the female fifth feet, each of the first basal segments is armed on the posterior surface with a very strong tooth-like projection in place of the eustomary spine. The lateral hair of the second basal segment is rather stout. The length of the first segment of the exopodite is twice its breadth. The hook of the second segment is strongly curved, and is denticulate on its inner margin. The third segment is represented by two spines: these spines are unusually long. The endopodite is slender and somewhat longer than the first segment of the exopodite. Its tip is setose, and armed on the immer side with two long, slender spines.

In the fifth feet of the male, each of the first basal segments is armed on its posterior surface with a strong tooth-like process in addition to the enstomary spines. The seeond basal segment of the right foot is longer than broad. On the posterior distal surface near the inner margin is a small hyaline process. The first segment of the exopodite is quadrate; it is prolonged slightly on its outer distal angle, and on its posterior surface near the inner margin bears a broad quadrate hyaline process, whose length nearly equals that of the segment. The second segment of the exopodite is twice the length of the first, is broad at the proximal end, and narrow at the distal end. The proximal end is nearly three times as broad as the distal. The lateral spine is situated at the proximal third, is long, strongly curved, and serrulate on its inner margin ; its length about equals the length of the segment. The terminal hook is as long as the rest of the right foot. It is slender, strongly curved, slightly angular, and 
denticulate on its inner margin. The endopodite is one-segmented, conical in form, slightly exeeds in length the fir'st segment of the exopodite, and is setose at tip.

The left fifth foot of the male reaches slightly beyond the first segment of the right exopodite. The second basal segment is quadrate, considerably smaller than the corresponding segment of the right foot. The lateral hair is situated near the distal end of the segment. The first segment of the exopodite is twice as long as broad, narrowing to the distal end. The outer margin is curved, and the inner has a rounded elevation at its middle. The second segment is shightly longer than the first. It is setose, especially on its inner surface. It is terminated with a long finger-like process, which is apparently jointed, and a slender falciform process on the inner side. The endopodite is one-segnented, slender, conical, setose at the tip, and extends to nearly one-half the length of the second segment of the exopodite.

Length of female, $1.31 \mathrm{~mm}$. Length of male, $1.2 .2 \mathrm{~mm}$.

The original description of this species was from material collected by Professor Birge near New Lisbon, Wisconsin. Very few individuals were found, but as it seemed so distinct in its characteristics from any other American species, there was no hesitation in describing it. As time went on, howerer, and no other specimens were found, although the state of $\mathrm{Wis}$ consin was pretty thoroughly explored, it becane a question whether it were not an abnormal form. it was something of a relief to the author, therefore, when the identical form was found in material collected by Mr. Channeey Juday in Winona lake, Warsaw, Indiana In Mr. Juday's collections it was present in considerable numbers, associated with 1 ). oregonensis. The two species were easily separated, as D. Birgei is distinctly larger than $D$. oregonensis.

In the fall of 1904 I collected the species at Richmond, Indiana, and, just as I was finishing the preparation of this report, I found it in material collected by Professor H. S. Pratt at Cold Spring Ilarbon, Long Island. It is not likely that it oceurs in many other Wisconsin localities, for pretty 
extensive colleetions have been made in that state, but it would seem probable that it must oceur in many localities between the Mississippi valley and the sea-board.

In the description, as given above, the original deseription is modified by the more complete knowledge made possible by the study of a larger number of individuals.

DiAptomes siciloides Lilljeborg.

Plate XVIII, fig. 9. Plate XIX, figs. 4, 5, 7.

1889. Diaptomus siciloides Lillj., DeGuerne and Richard, p. 54 ; pl. I, figs. 7, 8, 28, 32.

1895. Diaptomus siciloides Herrick and Turner, p. 69; pl. VIII, fig. 10.

1897. Diaptomus siciloides Schacht, p. 154.

1898. Diaptomus siciloides Brewer, p. 125.

1905. Diaptomus sicitoides Pearse, p. 147; pl. XIII, fig. 5; pl. XIV, figs. 7, 8.

A small species. The first segment of the eephalothorax about equals in length the three succeeding segments. The last segment terminates in two lateral spines.

The first abdominal segment of the female a little exceeds in length the rest of the abdomen. It is expanded laterally and in front, and bears two small lateral spines. The second segment is considerably shorter than the third, and the third and the furcal rami are abont equal. The fureal rami are ciliate on the inner margin.

The antennae are 25-jointed and reach the extremity of the fureal rami. The right male antenna is much swollen anterior to the genienlating joint. The antepenultimate segment bears a hook which equals in length one-half of the penultimate segment.

The first basal segments of the female fifth feet are armed with the customary spines, and the second basal segments with the usual lateral hairs. The exopodite is composed of two segments, the third segment being represented by two spines. 
The second segment is prolonged into the usual hook, which is denticulate on the inner margin. The endopodite equals the length of the first segment of the exopodite, and the tip is armed with hairs and the two terminal spines.

The fifth feet of the male are slender, and the left foot reaches the distal end of the first segment of the right exopodite. The first basal segments are armed with rather large spines. The second basal segment of the right foot has the lateral hair situated at about two-thirds of its length. The length of this segment is about twice its width; it bears upon the distal half of its inner margin a thin hyaline lamella, quairangular in form. This projects rather from the posterior surface than immediately from the inner margin. The second segment of the exopodite is about twice the length of the first segment. It bears a small spine on its inner margin at about ons-third of its length. The lateral spin 3 is small, curved, and situated at about two-thirds of its length. The terminal hook is falciform, symmetrically curved, and nearly equals in length the rest of the foot. The right endopodite is small and slender, and reaches about one-lialf the length of the first segment of the exopodite. It is armed at the tip with minute hairs. The lateral hair of the second basal segment of the left foot is situated near the distal end of the segment. The two segments of the exopodite are about equal in length and are oval in form. The first segment is setose on its inner margin. The second segment is swollen at the base on its inner margin into a cushion which is setose. The tip is setose and armed with two short finger-like processes. The endopodite is very slender, reaches about one-half the length of the second segment of the exopodite, and is hairy at the tip.

The above description is like that of Lilljeborg with a few corrections and additions. In his description he states that there is a hyaline appendage of the first segment of the exopodite of the male fifth foot that is "somewhat dilated." $\mathrm{i:}$ his figure this appendage is made somewhat triangular in form. In all the specimens I have seen, the appendage has been distinetly quadrangular as I have figured it. I have not 
seen Lilljeborg's types, nor have I seen any specimens from the locality in which his specimens were obtained. If his figure is correct, the form which I have seen would be a variety of $D$. siciloides, but as the agreement in all other details is so close, one camnot help thinking that thr exact form of this appendage was orerlooked. The endopodite of the right male fifth foot I lave found to vary considerably in length, some. times being nearly as long as the first segment of the exopodite.

Length of the fenale, according to Lilljeborg, 1.:3 $\mathrm{mm}$. I have found considerable variation in the length from different localities. My southern specimens measured as follows:-female, 1.225 nm1.; male, $1.1125 \mathrm{~mm}$. The Wiscomsin specimens were somewhat smallor, the females being $1.06 \mathrm{~mm}$. and tha males $1.01 \mathrm{~mm}$.

The type specimens were found in Lake 'Tulare, near Fresno, in Califormia. Schacht states that it was the most abundant species in the Illinois river near Havana. He has found it also in collections from Spirit lake, Iowa. I have found it in material collected by Professor Eigenmann in 'Turkey lake, Incliana, and in collections made by Professor Birge in Hutchins, Texas, and in Crève Coeur lake, St. Lonis. Pearse finds it in Nebraska. It was present in collections made for me by Mr. Shelford in Kansas, and I have recently found it near Hugo, Colorado. It seems likely that it will be found in the mountain region, thus bridging over the space between Colorado and California. I have found it in one locality in Wisconsin, in Cedar lake, Washington county, where it seens to be the only species.

The distribution of the species is a matter of a good deal of interest. It is found from Indiana on the east to California on the west, and from Texas on the sonth to Wisconsin on the north, but nevertheless seems to he a peculiarly loealized species. Doubtless many other localities will he fomd, for our knowledge of the distribution of Entomostraca is stili rery meager; but some localities have been pretty thoroughly sturlied; we know the IVisconsin fanma quite well, and it seems strange that the species should have localized itself to such an extent in Ceclar lake. 
daptonus trelal Poppe.

Plate XIX, figs. 2, 3, S.

1888. Diaptomus Tyrelli Poppe, p. 159.

1889. Diaptomus Tyrelli DeGneme and Richard, p. :39; pl. I, figs. 17,18 ; pl. IV', fig. 26 .

1895. Diaptomus Tyrolli Herrick and Tumer, p. 76; pl. X, fig. 9 .

1897. Diaptomus Tyrelli Schacht, p. 176.

Of medium size. The suture of the first cephalothoracic segment is rather distinct. The first segment is considerably less in lengtl than the thres following. The last ecphalothoracic segment is expanded into large lateral processes, and is armed with rather large lateral spines.

The first segnient of the female abdomen equals in Jength the rest of the abdomen. It is broad, dilated in front, and moderately dilated laterally. It bears prominent lateral processes, which are tipped with acute spines. The second segment is shorter than the third, and the two together are somewhat longer than the furca. The furcal rami are stont and ciliate on both the inner and the onter margins.

The antennae are 25-segmented and reach about to the end of the furca. The antepenultimate segment of the right male antenna is withont any special appendage.

The fifth feet of the female are slender. The spines of the first basal segments are small and acute. The lateral hair of the second basal segment is of moderate length. The first segment of the exopodite is more than twice as long as wide. The second segment is long and slender, exceeding in length the first segment. The hook is slightly enrved and denticulate on the inner margin. It is amed with three spines of which the inner is the longest. The two inner spines represent the third segment. The endopodite is long and slenter, exreeding in length the first segment of the exopodite. It is setose at the tip, and amed with two lomg terminal spines which are inserted well back from the end of the endopodite. 
In the male fifth feet, the spines of the first basal segments are prominent and acute. The second basal segment of the right foot is twice as long as broad. The lateral hair is situated at the beginning of the distal third. The first segment of the exopodite is quadrate, and bears a hyaline process on the immer distal angle. The second segment is strongly curved and equals in length the first basal segment. The lateral spine is straight and rather small and situated just distad of the middle. The terminal hook is slender, slightly curved, and equal in length to the rest of the foot with the exception of the first basal segment. It is denticulate on the inner margin. The endopodite is small, much less in length than the first segment of the exopodite. It is ordinarily pointed, but in some cases the tip is rounded. The left foot reaches to the end of the first segment of the right exopodite. The second basal segment is as long as wide, and strongly convex on the inuer margin. The lateral hair is situated near the distal end. The first segment of the exopodite is much longer than wide and setose on the inner margin. The second segment is about one-half the length of the first, and the inner surface is a convex setose pad. The segment is terminated with two digitiform processes, of which the outer is the longer. The endopodite is long and slender, reaching to the middle of the second segment of the exopodite. It is either one-segmented or indistinetly two-segmented. The tip is distinctly setose.

Length, accordng to Poppe: female, $1 \mathrm{~mm}$.; male, $1.5 \mathrm{~mm}$.

Length, according to Lilljeborg: female, $1.9 \mathrm{~mm}$; male, 1.8 mm.

My specimens averaged: female, $1.258 \mathrm{~mm}$; male, $1.15 \mathrm{~mm}$.

The original description by Poppe was from material collected at Summit lake in the Rocky mountains, at a height of 5300 feet. Lilljelørg's material was from Centerville, near Fresno, California.

The material from which my drawings were made was collected by the U. S. Fish Commission in Alturas lake, Idaho. Probably, then, it is widely distributed in the mountain region of the West. 
In the description as given above, I have adhered very closely to the description given in De Guerne and Richard's Révision, and the changes which I have made have been mostly in the way of minor additions. It would appear that the specimens of the three localities thus far known are very nearly identical in their structure.

DIAPTONes Leptopus Forbes.

Plate XX, figs. 1, 2, 5, 7 .

1882. D. leptopus Forbes, p. 646 ; pl. VIII, figs. 17-19.

1884. D. longicornis var. leptopus Herrick, p. 140.

1889. D. leptopus DeGuerne and Richard, p. 21 ; pl. II, fig. 19 ; pl. III, fig. 9.

1893. D. leptopus Marsh, p. 195 ; pl. III, figs. 4, 5.

1895. D. leptopus Herrick and Turner, p. 64; pl. II, figs. 1-10; pl. IX, fig. 9.

1897. D. leptopus Schacht, p. 130.

The last cephalothoracie segment is armed laterally with two minute spines.

The first abdominal segment of the female is somewhat less in length than the remainder of the abdomen and the furea. It is dilated on the sides. and armed laterally with minute spines. The second segment is very short, aud hardly distinguished from the first. The third segment and the furca are very nearly equal in length. The inner margins of the furca are ciliate.

The antennae reach to the end of the furca. The right male antenna is much swollen anterior to the geniculating joint; the antepenultimate segment is armed with a hyaline lamella extending its whole length, and prolonged slightly beyond the distal end of the segment.

The first basal segment of the female fifth foot is armed with the customary spine. The second basal segment has the minute lateral hair at about the middle of its outer margin. The exopodite is composed of two segments. The third segment is represented by two spines, the outer being the smaller. The 


\section{Wisconsin Academy of Sciences, Arts, and Lettors.}

endopodite neariy equals in length the first segment of the outer ramus. The two terminal spines are rather long, and the inner margin of the tip is setose.

The first liasal segment of the right fifth foot of the prale is armed with a spine of moderate size. The second basal segment is quadrangular in form, its length being about twice its width. The lateral hair is situated nearly at the distal end of the segment. Near the distal end of the segment, on the posterior surface, is a shelf-like projection, from which arises a blunt hook which extends distally over the proximal end of the first segment of the exopodite. The first segment of the exopodite is quadrangular, about twice as long as wide. The second segment of the exopodite is rather slender, its length being. somewhat less than three times its width. The lateral spine is short, and situated well towards the distal end of the segment. The terminal hook equals in length the preceding segment, is slightly curved, and is sermlate on its immer margin. The endopodite is somewhat variable in length, sometimes being about two-thirds the length of the first segment of the exopodite, and at others nearly equaling that segment. It is armed with fine hairs at the tip. In the left fifth foot of the male, the spine of the first basal segment and the lateral hair of the second are siturated as in the right foot. The length and width of the second basal segment are about equal. The first segment of the exopodite is abont twice as long as wide, quadrangular in form, with its immer distal angle setose. The second segment is irregnlar in form, ahout four times ss long as wide, setose on the imner margin. It is armed on the distal extremity with a finzer-like process and a long, curved spine; this spine is setose. The endopodite is slender, somewhat curved at its distal part, and considerably longer than the first segment of the exopodite. It is setose on the inner margin of the tip.

Authors vary -onnewhat in regard to the length. In Forbes's original paper, the average length is given as $1.778 \mathrm{~mm}$., no distinction heing made as to sex. De Guerne and Richard grive. the imgth as about $1.5 \mathrm{~mm}$. Helrick and Tumer give the lemetli of the female as 1.5 to $1.7 \mathrm{~mm}$., and that of the male as 
$1.4 \mathrm{~mm}$. Schacht's measurements are somewhat larger-viz., female, $1.89 \mathrm{~mm}$, and male, $1.83 \mathrm{~mm}$. The differences in these measurements are not very oreat, and probably arise from the measurement of a comparatively small number of spseimens in cach case.

This species seems to be generally distributed through the Mississippi valley.

daptomus leptorus var. piscinae Forbes.

Plate XX, figs. : 6, 8. Plate XXI, fig. 7.

1893. Diaptomus piscinae Forbes, p. 25:; pl. XLT, fig. 22. 1595. Diaptomus piscinae Herrick and Tumer, p. 74 ; pl. V, fig. 13.

1897. Diaphomus piscinae Schacht, p. 125; pl. XXII, figs. 1-4.

The original description of this form by Forbes was from specimens obtained from a small lake near Gardiner, Montana. Sehaeht reports it in collections from Portage Slongh, Manitoba. I have found it in collections made by $\mathrm{Mr}$. Congdon in Bireh Hills, Alberta, and in material sent by Mr. Juday from a lake on the University campus in Bonlder, Colorado. The points of difference made by Forbes to distingnish this from $D$. leptopus are the length of the setae on the endopodite of the female fifth foot, the more slender form of the fifth feet of the male, and the absence of the antennal hook. These differences undoubtedly exist with the exeeption of the absence of the antennal armature. I find in all my speeimens the hyaline lamella of the antepenultimate segment of the right male antenna just as in D. leptopus, but not quite so pronounced. Professor Forbes kindly loaned me some slides of $D$. piscinae, and in the only one which showed the male antennae the hraline lamella was present, though the antenna was turned so that it might easily eseape notice.

I have noticed eertain other points of difference between the two forms. The endopodites of the male fifth feet are consid erably louger in $D$. piscinac. The third segment of the exopo- 
dite is indistinctly separated, is armed with two spines, and there is a third spine on the second segment. This spinal armature was remarked by Forbes, but Schacht speaks of the third segment as armed with "two or three spines." Schacht also speaks of three spines in D. leptopus, and the figure of De Guerne and Richard has three spines. In my statement, as given before, I have said that there are only two spines in $D$. leptopus, as that has miformly been the case in the specimens I have examined. It is very possible that this is a variable feature, and while I have considered this one of the points of difference of the variety, I think it very likely that it is not a matter of even varietal distinction. The second segment of the abdomen in $D$. piscinae, I have found considerably longer than in typical $D$. leptopus.

It seems to me that these differences are so slight that they certainly should not be considered specific, and it is a question whether they should even be thought enough to constitute a variety. I have no doubt that further collections will bring to light connecting forms, but it may be best, for a time at least, to retain the varietal name.

\section{DIAPTOMUS STAGNALIS Forbes.}

\section{Plate XXVII, figs. 3, 6, 7 .}

1882. Diaptomus stagnalis Forbes, p. 646 ; pl. VIII, figs. 8, $10,11,12,14$.

1882. Diaptomus giganteus Herrick, p. 222: pl. II, figs. 3, $11,15$.

1884. Diaptomus stagnalis Herrick, p. 139 ; pl. Q, figs. 11, 13. 1889. Diaptomus stagnalis DeGuerne and Richard, p. 23 ; figs. 15,16 ; pl. IV, fig. 14.

1895. Diaptomus stagnalis Herrick and Turner, p. 66 ; pl. III, figs. 1-12; pl. XIII, figs. 11, 13.

1897. Diaptomus stagnalis Schacht, p. 138; pl. XXVIII, fig. 2.

"Head distinet from thorax; fifth and sixth thoiacic segments confluent. Lateral angles of last thoracic segment strongly 
produced backward, each angie bilobed, the outer lobe about twice as large as the inner (in the male this segment is salient). Abdomen peculiar in that there is a sudden narrowing at the beginning of the third segment. First abdominal segment of the female armed with a large spine on each side; second and third segments subequal, about twice as wide as long. Furcal rami subquachate, ciliate on the inner margin. Furcal setae rather short, densely plumose. There is but little difference in the length of the abdominal segments of the male.

"Antennae 25-segmented, reaching to the middle of the abdomen. The right antenna of the male is greatly swollen anterior to the geniculating joint. The antepenultimate segment bears a broad hook-like process, which does not reach to the end of the penultimate segment.

"Second basal segment of the fifth foot of the female with the usual delicate hair at the outer margin. First segment of the exopodite short and broad. Second segment large, about one and one-half times as long as the first, armed on the middle third of the inner margin with seven or eight very large, strong, pointed spines, and on the outer margin and opposite the upper spines of the inner margin with three or four spines. Third segment distinct, armed with two spines, the outer one short, thick, sharp, smooth, the inner one about twice as long and armed with a few rather strong spinules. Just withont these spines, on the second segment, is a shorter smooth spine. The endopodite of the fifth foot of the female is distinctly two-segmented, the first segment subquadrate, the second as wide as the first and nearly twice as long, and armed at the tip with two thick, heavy spines reaching to the cnd of the second segment of the exopodite. These spines are armed with heary spinules. Disregarding the spines, the endopodite reaches just to the end of the first segment of the exopodite.

"Second basal segment of the right fifth foot of the male subquadrate, about twice as long as wide; on the posterior surface a large, smooth, hyaline lamella occupying about a third of the inner margin near the middle, and near the outer distal angle a minute cuticular process bearing a delicate hair. First seg- 
nient of the exopodite almost three times as long as broad; second segment about as long as the first and for about the proximal third nearly as wide, hut herond this considerably broader. Marginal spine near the onter distal angle; straight, rery strong and thick, a little less than half as $\operatorname{long}$ as the segment. Teminal hook rather short and very stout, irregularly curved, heavily and closely denticulate at the distal half of the inner margin. Endopodite of the right fifth leg spatulate, not nearly reaching the middle of the first segment of the exopodite; apex rounded, armed with a few strong spines.

"Second basal segment of the left fifth foot amed at the outer" margin, a short distance above the distal angle, with a short, thick, pointed spine. First segment of the exopodite about three times as long as wide, armed at the distal third of the inner margin with a few strong hairs. Second segment about half as long as the first, having on the inner margin two cushionlike processes (the upper, smaller one hairy, and the lower densely tuberculate), and being armed at the tip with two processes forming a forcipate structure, the onter broad, plowshareshaped, the inner a long and narrow spine, hairy within. Endopodite of left fifth foot one-segmented, of the same width thronghout, with a broadly rounded tip; inner margin rugose.

"Length of female, 4 to $4.5 \mathrm{~mm}$. Length of male, 3.5 to $4 \mathrm{~mm}$.

"This Diaptomus is the largest of the American species and a very beautiful one. Dr. Forbes states in his original deseription that all were red thronghont. Specinens taken in April, 1897 , from ponds south of Urbana, Illinois, when ther were in the height of sexual activity, were colored as follows; thorax and anterior appendages (all but the first pair of antennae) blue; first pair of antennae, fifth pair of legs (in the male), and abdomen red. In the female all the legs were blue."

The preceding description was taken from Schacht and was, presumably, prepared under the supervision, or with the cooperation, of Professor Forbes. I have been unable to obtain any of the Illinois material for verification of the descripticn, and the species has not occurred in the territory from which 
my collections have been made, although it is reported as oceurring not only in Illinois and Minnesota, but in Ohio, Kentucky and Alabama.

The segmentation of the fifth feet of the female would indicate that this is one of the least specialized of the members of the leptopus group.

DIAPTOMUS CONIPEDATUS sp. nov.

Plate XX, fig. 4. Plate XXI, figs. 2-4.

A rather large species. The first cephalothoracic segment is nearly as long as the succeeding three segments. The last cephalothoracic segment has two minute spines on each lateral lobe.

The first abdominal segment of the female is somewhat less in length than the rest of the abdomen and the furca. It is dilated in front, and slightly dilated at the sides. The lateral dilatations are armed with small spines. The second and third segments are about equal in length, and are broader than long. The rami of the furca are somewhat longer than the third segment and are ciliate on the inner margin.

The antennae hardly reach the end of the furea. The right male antema is much swollen anterior to the geniculating joint. The antepenultimate segment is armed with a hook-shaped process, which is not strongly recurved; it is rather less than half as long as the pennltimate segment.

The first basal segment of the female fifth foot has the usual spine upon its posterior surface. The second basal segment has the customary lateral hair. The first segment of the exopodite is short and stout. The second segment is stout and prolonged into the usual hook which is denticulate on the inner margin. The third segment is represented by two spines. There is also a third spine situated outside these two. The endopodite is much longer than the first segment of the exopodite, is armed with short hairs on the inner margin of the tip, and has two rather long terminal spines. 
The spines of the first hasal segments of the male fifth feet are long' and slender. 'The second basal segment of the right foot is nearly twice as long as wide. The lateral hair is long and slender and situated on the distal fourth of the segment. On the posterior surface not far from the middle line are two hyaline lamellae projecting inward. The proximal lamella is accompanied with a spine, and the distal lamella with a recurved hook. 'The first segment of the exopodite is twice as long as broad, and has a blunt process on its outer distal angle. The second segment is twice as long as the first, is stender, very narrow at the proximal ond, and grows gradually wider towards the distal end. The lateral spine is near the distal end, is rather long, and nearly straiglit. The terminal hook is very stout, almost conical in shape, and much shorter than the second segment. The endopodite is very sinall, appearing as a small process on the inner distal angle of the second basal segment. The length of the second basal segment of the left male tifth foot is a little less than twice its width. It is slightly concave on the outer margin. The lateral hair is situated well towards the distal end of the segment. The fiist segment of the exopodite is three times as long as wide, and somewhat concave on both the inner and onter margins. The distal inner angle is setose. The second segment of the exopodite is slightly concave on the inner nargin, and is terminated with a finger-like process and a longer faleiform spine. The endopodite is long and slender, reaching beyond the first segment of the exopodite, is ob:curely two-segmented, and is setose at the tip.

Length of female, $1.49 \mathrm{~mm}$. Length of male, $1.325 \mathrm{~mm}$.

This was fonnd in collections narle by Profensor Birge at Slidell, Lonisiana. Only a few specimens were found, but it seens to be a well-marked species. It resembles in many respects D. Lintoni and D. slagnalis, but differs in some marked particulars.

The noticeable points of difference from $D$. Lintoni are the form of the appendage of the antepenultimate segment of the right male antema, the form of the terminal segment and hook of the right male exopodite, and the terminal setae of the en. 
dopodite of the female fifth foot. It resembles $D$. stagnalis in the antennal armature and in the general form of the male fifth feet; lont it differs in the male fifth feet, in the form of the second segment of the exopodite, and in the form and size of the endopodite. It differs in the female fifth feet in the fact that the terminal spines are shorter, and that the third segment is not distinct.

diaptomus clayipes Schacht.

Plate XX, fig. 9. Plate XXI, figs. 1, 5, 6.

1897. Diaptomus clavipes Schacht, p. 178; pl. XXXIV, figs. 1-3; pl. XXXV, figs. 1, 2.

1598. Diaptomus nebrasliensis Brewer, p. 123; pl. VII, figs. $1-4$.

1902. Diaptomus claripes Beardsley, p. 45.

1905. Diaptomus clavipes Pearse, p. 147; pl. XIII, fig. 6.

A large species. The first segment of the cephalothorax is equal in length to the three following. The last segment of the cephalothorax is armed with two small lateral spines.

The first segment of the female abdomen is longer than the rest of the abdomen. It is much dilated in front and somewhat laterally. The lateral dilatations are not abrupt as in many species. There are two small lateral spines. The third segunent is very short. The furea is about equal in length to the two preceding segments. The fureal rami are ciliate on the inmer margin.

The antemac are 25 -segmented, barely reaching the end of the furea. The right antenna of the male is much swollen anterior to the genionlating joint; the antepenultimate segment is armed with a lateral hyaline lamella.

The spines of the first basal segments of the female fifth feet are rather wnall and blunt. The lateral hairs of the second basal scoments are of moderate lengtli. The length of the first segment of the exopodite is less than twice its width. The serond segment is stout, and the hook is almost straight. It 
is strongly dentieulate on the inner margin and less so on the outer. It is armed with three spines. The inner two are upon a distinet base, which represents the third segment. These two spines are pectinate, and the inner is considerably the longer. The endopodite is slender, about equal in lengtis to the first segment of the exopodite. It is setose at tip and armed with two long plumose spines.

The spines of the first basal segments of the male fifth feet are small and aeute. The second basal segment of the right foot is quadrate, with the lateral hair situated near the distal angle. Upon its posterior surface near the inner distal angle is a short hook-like process. On the inner margin at a little less than half its length is a small conical process. From the middle of the posterior surface near the distal end arises a stout faleiform process which nearly equals in length the first segment of the exopodite. The first segment of the right exopodite is equal in length to the second basal se?ment. It is areuate, the inner surface being coneave and the outcr convex. The seeond segment is longer than the first, quadrangular, and las the lateral spine at the outer distal angle. The terminal hook is rather stout, faleiform, symmetrieally curred, and equal in length to the segments of the exopodite. The inner margin is markedly dentieulate. The endopodite springs from the inner margin of the seeond bacal segment. It nearly equals one-half the length of the first segment of the exopodite. It is setose at tip.

The left foot reaches to the end of the first segment of the right exopodite. The second hasal segment is trapezoidal in form, as wide as long, and has the lateral hair near the distal angle. The first segment of the exopodite is longer than wide and setose on the inner distal angle. The second segment of the exopodite is long and slender, arising from the outer half of the distal end of the preeeding segment. Its margins are slightly eoneave, and the inner margin is setose. It is terminated by a digitiform process and a stout spine. This spine is armed on its inner surface with stout spinules. The endopodite is long and slender, reaching one-half the length of the 
second segment of the exopodite. It is spatulate in form, armed at the tip with blunt spines, and with very minute spines over its whole surface.

Length of the female, according to Schacht, $1.37 \mathrm{~mm}$. Length of male, $1.68 \mathrm{~mm}$. According to Brewer, the female varies from $2.25 \mathrm{~mm}$. to $2.5 \mathrm{~mm}$. I have not at hand enough mature specimens to get a good average of size.

Formd, according to Schacht, in West Okoboji lake, Iowa. Brewer's material was found near Lincoln, Nebraska. Found by Beardsley in Greeley, Colorado.

The above description was written from material sent by Brewer. Schacht's description does not correspond in all details. He states that the female abdomen is asymmetrical. This asymmetry was not noticeable in my material. He speaks of the peculiar hook of the male fifth foot as on the first segment of the exopodite. In iny specimens it is on the second basal segment, and his figures show the same situation. This lack of correspondence between Schacht's figure and description has already been noted by Beardsley ('02). On the second segment of the exopodite of the female fifth foot. Schacht says there are two spines, of which the outer is the longer. I find three spines, and the innermost is the longest. His figurc makes the inner the longest. His figure, too, omits the terminal spines of the endopodite of the female fifth foot, although he speaks of them in his text. There is a difference, too, in the length of the abdominal segments as compared with the Nebraska material.

If these differences exist and are constant, D. nebraskensis must be considered a variety of $D$. clavipes. I think it probable, however, that if material were available for a comparison of specimens from the two localities, it would appear that there is not even a varietal difference. 
454 Wisconsm Academy of Sciences, Arts, and Letters.

diaptomus intoni Forbes.

Plate XXVII, figs. 4, 5, 7.

1893. Diaptomus Lintoni Forbes, p. 252; pl. XLII, figs. 2628.

1895. Diaptomus Lintoni Herrick and Turner, p. 68; pl. V, fig. 12.

1897. Diaptomus Lintoni Schacht, p. 127; pl XXVII, fig. 1.

"A large red species occurring commonly with D. shoshone; but distinguishable from it at a glance by its different shape, its longer antennae, its smaller size, and by characters derived from the right antemna and the fifth foot of the male. The thorax is symmetrically elliptical in shape, broadest at the middle. The posterior angles are not produced or bifid, but are each armed with a minute spine. The first segment of the abdomen of the female is not especially produced, but bears at its broadest part a minute spine on each side. The abdomen itself is very short, its length contained about three and onethird times in that of the cephalothorax. The antenna of the fenale is long and slender, 25-jointed, reaching a little beyond the tip of the abdomen.

"The fifth pair of legs in this sex is similar to those of $D$. shoshone, but much smaller. The inner ramus is not jointed. It is longer than the basal joint of the outer ramus, bears two stout plumose setae at its tip, somewhat shorter than the ramus itself, and has likewise at its inner tip a patch of small spines or fine hairs. The second segment of the outer ramms with its teminal claw is two-thirds as long again as the preceding segment, the breadth of the latter two-thirds its length. The third joint is indicated lyy a single long, stout seta and one or two smaller ones.

"In the male the geniculate antenna is relatively rather slender, its last two joints without special appendages, its penultimate with a slender transparent apical process, reaching about to the middle of the succeeding segment, aente at tip, but neither serrate nor emarginate. 
"Fifth pair of legs in the male usually without internal rimus to the right leg, but this ramus sometimes represented by a small rudiment. The limb is usually slender, and its terminal claw short. The basal segment of the outer ramus is nearly as long as the adjacent seginent of the predicel, and the slender second scgment of this ramus is fully as long. Long lateral spines are borne near the tip of this segment. The terminal claw is about two-thirds as long as the segment, is somewhat abruptly angulated near its base, and slightly recurved at the tip. The inner ramms of the left leg is very stont and long, reaching almost to the tip of the outer ranus, is slightly curved outwards, and has the apex minutely hairy. The basal segment of the outer ramus is thick, two-thirds as broad as long, somewhat inflated within, where it extends downward beyond the articulation with the second segment as a rounded expansion covered with extremely fine hairs. Secend segment of this ramus lomger than first, but only half as wide, bearing at its tip, within, a rather small, obliquely projecting eushion covered with cilia, and with two stout terminal spines, one short, blunt, straight, smooth, the other enrved and plumose, its length about half that of the segment to which it is attached.

"The total length of this speries is about $2.5 \mathrm{~mm}$., excluding caudal setae; depth, .t2 $11 m$.

"This species is closely related to D. stagnatis Forbes, from which it differs conspicuously by its smaller size, more symmetrical cephalothorax, without prominent or bificl angles, and longer and more slender antennae, with longer and more slender appendage to the antepenultimate segment.

"In the fifth legs of the female this species differs from $D$. stagnalis, especially with respect to the inner ramus, which is larger and longer than in the other, lacks the characteristic seg mentation of $D$. stagnalis, and hears at its tip shorter and broader setae. In the male the terminal claw of the outer ramus of the right fifth ley is much more slender than in $D$. stagnalis, and the inner ramus is much less developed. The left leg of this pair is different in a number of details, especially in the length and strength of the inmer ramns and 
the length and dissimilarity of the setae at the end of the outer.

"Common in lakes and pools in Yellowstone park."

The abcre is a verbatim copy of the description of Professor Forbes. Nothing was added by Herrick or Schacht. The species has not apperred in the collections which have come to me, and I regret that I have not had an opportinity to study the original collections. The figures of the plate are copies of the original figures of Forbes.

diaptonus spatulocrexatus Pearse.

1906. Diaptomus spatulocrenatus Pearse, p. 246 ; figs. $6-9$.

Of moderate size. The first cephalothoracic segment is three-fourths the length of the cephalothorax; it has a transverse groove at about its middle. The last segment is produced posteriorly and armed with two sharp spines on each lateral lobe.

The abdomen of the female is stout. The first segment is longer than the remainder of the abdomen. The second segment is one-sixth as long as the first and one-half as long as the third. The furcal rami are one-fourth longer than wide and ciliate on the inner margin.

The antemnae are 25 -segmented and reach to the end of the furca. The right antenna of the male is swollen anterior to the reniculating joint. The antepenultimate segment bears a hook-shaped process, which is fully half as long as the penultimate segment.

The first basal segments of the fifth feet of the female are armed with strong spines. The lateral hairs of the second basal segments are weak. The exopodite consists of two segments. The sccond segment is prolonged into a hook, which is denticulate on the inner margin; it bears on its outer margin three spines, of which the inner is the longest and is distinctly plumose. The endopodite exceeds in length the first segment of the exopodite, is setose at the tip, and bears two long plumose spines. 
The spines of the first basal segments of the fifth feet of the male are rather long and slender. The second basal segment of the right foot is about twice as long as broad, and c nrex on inner and outer margins. The lateral hair is situated at about two-thirds of its length. It bears a small tubercle on the posterior surface, near the inner margin, at about one-thir - its length. The first segment of the right exopodite is twice as long as wide, convex on the outer margin and concave on the inner; the second segment is three times as long as wide, strongly concave on the inner margin and convex on the outer. The lateral spine is near the outer distal angle, is of medium length and slightly curved. The terminal hook is stout, nearly as long as the segment, bent sharply at about the middle. It is denticulate on the inner margin. The endopodite is rudimentary, being represented by a short, curved process.

The left foot, in length, does not reach the end of the first segment of the exopodite of the right foot. The second basal segment of the left foot is trapezoidal in form, three-fourths as long as the corresponding segment of the right foot. The lateral hair is at about two-thirds its length. The first segment of the exopodite is one-half as wide as the seconc' basal segment, is twice as long as wide, with rounded apical angles; the inner distal angle is setose. The second segment is less than two-thirds the length of the first, is concave on the inner margin and convex on the outer. It is armed at the tip with a stout finger-like process at the onter angle, and a slender curved process at the inner angle. The process at the onter angie is finely denticulate on the imer margin, and the process at the inner angle is setose. The inner margin of the second segment is setose. The endopodite is two-segmented and nearly equals in length the exopodite. The first segment is slender. The second segment is oval, crenate on the inner margin, and setose at the tip and on the imner and anterior surfaces.

Length of female, 1.47-1.55 mm. Length of male, 1.30$1.33 \mathrm{~mm}$.

This was found in Wigwam pond, Nantucket.

Pearse's paper containing the description, of which the above is nearly a rerbatim copr, modified only to correspond to the 
order of the other deseriptions, was received while this paper was going through the press. Consequently the author has not seen the type specimens, and there has been no opportunity to prepare figures. Pearse speaks of it as related to Lintoni, and it is evident that it falls into the leptopus group, being closely related to stagnalis as well as Lintoni. The form if the endopodite of the left fifth foot of the male is a distinctive characteristic.

DIAPTOMUS SIGNicauda Lilljeborg.

Plate XXI, figs. 8, 10, 11. Plate XXIT, fig. 3. Plate XXIII, fig. 3.

1859. Diaptomns signicanda DeGnerne and Richard, p. 55; pl. I, fig. 15, 16, .31; pl. III, fig. 22.

1895. Diaptomus signicaudatus Herrick and Turner, p. 63; pl. V'TII, fig. 1:; pl. IX, fig. 10.

1897. Diaptomus signicauda Schacht, p. 16t; pl. XXLX, figs. 3-6.

A small species. The eephalothorax is broadest in front of the middle at the second segment. The first segment is about twice the Iength of the second. The last two segments are confluent, and the last segment has rather broad projecting lateral lobes with acute posterior angles ending in sunall spines. The fourth thoracie segment has a slight dorsal gibbosity.

The first abdominal segment of the female is expanded in front and laterally, and is armed laterally with minute spines; on the posterior end on the right side it bears a finger-like process which projects backward. This process is somewhat variable in length. The sccond abdominal segment varies in length. In some cases it is hardly to be distinguished from the first segment (Pl. XXI, fig. 11), while in others it equals in length the third segment (Pl. XXIII, fig. 3). The fureal rami vary in length from one and a half times the breadth to twice the breadth. They are setose on the inner margin. 
The antennae are 25-segmented, and extend a little beyond the furcal rami. The antepenultimate segment of the right male antenna is armed with a small recurved hook.

The first basal segments of the fifth feet of the female are armed with rather large spines. The lateral hair of the second basal segment is short and weak. The exopodite is composed of two segments, the third segment being represented by two small spines. The second segment is prolonged into a rather stout hook which is delicately denticulate on the inner margin. The endopodite is slightly longer than the first segment of the exopodite, is composed of one segment, armed on the inner margin of the tip with hairs, and with two rather long terminal spines. The terminal spines are delicately ciliate.

The fifth feet of the male are rather slender. The first basal segments are armed with the customary spines. The second basal segment of the right foot is trapezoidal in form, and somewhat longer than broad. The lateral hair is situated at about two-thirds of its length. The first segment of the exopodite is also trapezoidal in form, of about half the length of the second basal segment, and is armed on its immer border with a hyaline lamella which is widened at the distal end and extends beyond the distai angle of the segment. The second segment of the exopodite about equals the combined lengths of the second basal segment and the first segment of the exopodite. The lateral spine is situated at the end of the second third of the segment. The terminal hook is symmetrically curved, and is somewhat longer than the two segments of the exopodite. The endopodite is broad, acmuinate, and shorter than the first segment of the exopodite.

The second basal segment of the left fifth foot of the male has its lateral hair situated almost at the distal angle of the segment. The first segment of the exopodite is longer than broad, its inner and outer margins are curved, and it is setose on the distal third of its immer margin. The second segment of the exopodite is twice as long as wide, the imner margin expanded both at the base and at the distal end, and setose. The distal end of the segment is setose, and armed with two finger- 
like processes. The endopodite is long and slender, reaching well towards the end of the second segment of the exopodite. It is setose on the inner margin of the tip.

Length of female, $1.5 \mathrm{~mm}$. Length of male, $1.3 \mathrm{~mm}$.

The original description was written from material obtained in the Sierra Nevada in California. It is probably pretty widely distributed through the mountain region of the West. I have found it in collections from Marlette lake, Nevada, ob. tained by Professor C. F. Baker, from Boulder lake, Colorado, and Hosketts lake, California, collected by Professor Chauncey Juday, and from several lakes in the Lake Tahoe region collected by Professol II. B. Ward. One peculiarity not given in the diagnosis should be noted, namely that the lateral spine of the exopodite of the male fifth foot does not lie in the same plane with the segment, but is curved to one side.

The projection on the first abdominal segment of the female, from which the species is named, is not present in the immature specimens, appearing only at maturity.

Diapomus nudus Marsh.

Plate XXI, fig. 9. Plate XXII, figs. 1, 2.

1904. Diaptomus nudus Marsh, p. 147; pl. XXX, figs. 1, \&, 4,5 .

Of moderate size. The first eephalothoracic segment is nearly equal in length to the rest of the cephalothorax. The last cephalothoracic segment is armed laterally with two minute spines.

The first abdominal segment of the female is somewhat longer than the rest of the abdomen. It is dilated laterally and armed on each side with a sharp spine. These spines are at about the termination of the first third of the segment. The distal margin of the segment is extended on the right side in a conical process which extends beyond the second segment. The second segment is very short, and is nearly covered by the first. The third segment is about one-third the length of the first, and is somewhat shorter than the furca. 
The antennae reach slightly beyond the end of the furca. The risht antenna of the male is swollen anterior to the geniculating joint. The antepenultimate segment bears upon its distal extremity a honk-like process which is rather less than half the length of the penultimate segment.

In the fomale fifth feet, the spines of the first basal segments are very pronounced. The second basal segments are armed with rather delicate lateral hairs. The first segment of the exopodite is stont. The second segment is of the nsual form, and the hook is denticulate on its inner margin. The third segment is represented by two spines. The endopodite equals in length the first segment of the exopodite, and is armed at the tip with two spines and with short hairs.

In the male fifth feet, the spines of the first basal segments are very pronounced. The second basal segment of the right foot is trapezoidal in form, and its length exceeds its average width by about one-half. The lateral hair is at about onethird of its length from the distal end. The first segment of the right exopodite is about as broad as long, and has its distal angle somewhat produced. The second segment of the exopodite is elongate, being more than three times the length of the first. The lateral spine is situated at abont one-third the distance from the proximal end, is hook-shaped, and is inserted at an angle with the plane of the segment--that is, it does not lie in the same plane with the flat surface of the segment. The terminal hook is elongate, falciform, with a regular curvature. The endopodite is short, rather less in length than the first segment of the exopodite, and is of a somewhat triangular form.

The second basal segment of the left foot is similar in form to the corresponding segment of the right foot, and is about one-half as long. The lateral hair is situated well towards the distal end. The first segment of the exopodite about equals the basal segment in length, but is more slender. The second segment is short, armed with a terminal pad, a pad on its inner surface, and with two blunt spines near the distal end. The pads are armed with short, stiff hairs. The endopodite is very slender and very nearly equals in length the two segments of the exopodite. 
Length of female, $1.132 \mathrm{~mm}$. Length of male, $1.115 \mathrm{~mm}$. This species was found in material collected by Professor H. B. Ward in Dead lake, Lake Michigan, Lake Rocks, and Mirror lake, - all these lakes being in the vicinity of Pike's Peak. It was especially abundant in the collections from Lake Nichigan.

DIAPTOMUS WASIINGTONEXSIS sp. nUt.

Plate XXII, figs. 5, 8, 9. Plate XXIII, fig. 2.

One of the smaller species. The first cephalothoracic segment is somewhat longer than the combined length of the three following segments. The last ecphalothoracic segment is armed with minnte lateral spines. The first segment of the female abrlomen is as long as the rest of the abdomen. It is expanded laterally and in front and bears two small spines laterally. On the posterior end on the right side it bears a finger-like process projecting backward. The second segment is ordinarily about one-half the length of the third. The furcal rami are abont twice as long as their width and are setose on the imer margin.

The antemae are 25-segmented, slightly longer than the entire body. The right male antenna is much swollen anterior to the genienlating joint, and the antepenultimate segment bears a recurved hook which is continuous with a lateral lamella extending back one-half the length of the segment.

The first basal segments of the female fifth feet are armed witlu rather large spines. The lateral hairs of the second basal segments are very bong and slender. The exopodite is composed of two segments, the third segment being represented by two small spines. In addition to these spines. there are sometimes present two other very minute spines. The second segment is prolonged into the enstomary hook, which is denticulate on the inner margin. The endopodite is slightly longer than the first segment of the exopolite, is composed of one segment, and armel on the inner margin of the tip with hairs, and has two rather long terminal spines. 
The fifth feet of the male are slender. 'The first basal segments are armed with the enstomary spines. The second basal segment of the right foot is trapezoidal in form and longer than broad. The rather long lateral hair is sitnated at abont twothirds of its length. The first segment of the exopodite is quadrate, its length considerably less than its width. The length of the second segment is somewhat greater than the combined lengths of the second basal regment and the first segment of the exopodite. The lateral spine is situatcd beyond the middle of the segment. The terminal hook is symmetrically curred and is considerably longer than the first two segments of the exopodite. The endopodite is triangular in form, much longer than the first segment of the exopodite, and is sometimes indistinctly two-segmented.

The second basal scgment of the exopodite of the tifth foot of the male has its rather long lateral hair situated almost at the distal angle of the segment. The first segment of the exopodite is about as long as broad, its inner and outer margins curved, the inner margin setose on its distal third. The second segment is half again as long as broad, the inner margin expanded at the base and at the distal end and setose. The distal eud is setose and armed with two finger-like processes. The endopodite is slender, reaches well towards the tip of the second segment of the exopodite, and is setose at the tip.

Length of female, about $1.15 \mathrm{~mm}$. Length of male, about $1.137 \mathrm{~mm}$.

This species was foumd in material collected for me by Professor B. H. Brown in Walla Walla, Washington.

The close relation of this form to $D$. signicauda is apparent. In the female there are distinctive differences. In the male, however, the structure of the antepenultimate segment of the right antemna and of the fifth foot are so different that I think the validity of the species eannot be qnestioned. The lateral lamella of the antemnal segment I have never found in $D$. signicauda, while it is characteristic of $D$. washingtonensis. The whole male fifth foot is much shorter and stonter in D. washingtonensis, the first segunent of the right exopodite has un hya- 
line lamella, the endopodite is longer and is sometimes indistinctly two-segmented. The left endopodite is very much shorter in D. washingtonensis.

DIAPTOMUS JUDAYI sp. nov.

Plate XXII, fig. 6. Plate XXIII, figs. 1, 5.

A small species. The first cephalothoracic segment is considerably longer than the three following. The last segment is armed with minute lateral spines.

The first segment of the female abdomen is longer than the rest of the abdomen. It is expanded laterally and in front and bears two small lateral spines. On the posterior end of the right side it bears a finger-like process projecting backward. This process is somewhat shorter than in the other species of the signicauda type. The second segment is about half the length of the third. The furcal rami are rather less than twice as long as their width, and are eiliate on the inner margin.

The antemnae are 25-segmented and extend a little beyond the furcal rami. The right antemna of the male is much swollen anterior to the geniculating joint, and bears a straight process on the antepenultimate segment. This process is two-thirds the length of the penultimate segment.

The first basal segments of the female fifth feet are armed with the customary spines. The second basal segments have rather long lateral hairs. The exopodite is composed of two segments, the third segment being represented by two spines. The second segment is prolonged into the usual hook-like process, and is denticulate on the inner margin. The endopodite about equals in length the first segment of the exopodite, is armed on the inner margin of the tip with hairs, and has two rather long terminal spines.

In the fifth feet of the male, the first basal segments are armed with rather large spines. The second basal segment of the right foot is trapezoidal in form and considerably longer 
than broad. The lateral hair is situated at about two-thirds of its length and is rather long. The first seginent of the exopodite is trapezoidal in form, and its length and width are about equal. It bears a thin hyaline lamella resembling that in signicauda, but it is more pointed at the distal end. This hyaline lamella is not inserted on the inner margin, but on the posterior surface, so that as viewed from some direetions only the distal end is visible, although it really extends the whole length of the segment. The second segment of the exopodite is somewhat shorter than the combined lengths of the first segment and the sceond basal segment. The lateral spine is situated proximad of the middle of the segment. The terminal hook is symmetrieally curved, and is somewhat longer than the two segments of the exopodite. The endopodite is broad, acuminate, nearly equaling in length the first segment of the exopodite. The second basal segment of the left fifth foot of the male las the rather long lateral hair situated almost at the distal angle of the segment. The first segment of the exopodite is slightly longer than broad, has its inner and outer margins curved, and is setose on the distal third of its inner margin. The second segment is nearly three times as long as broad, and has the inner margin expanded near the base and setose. It terminates in two finger-like processes, one of which is much larger than the other. The endopodite is long and slender, reaching two-thirds the length of the second segment of the exopodite.

Length of female, $0.93 \mathrm{~mm}$. Length of male, $0.9 \mathrm{~mm}$.

This form was found in material collected by Mr. Chauncey Juday in Twin lakes, Colorado, and the name is given in recognition of the many collections which Mr. Juday has had the kindness to send to me. The species in most respeets bears a very elose resemblanee to $D$. signicauda. The male fifth foot differs in the proportions of the segments, the form of the lamella of the first segment of the right exopodite, the position of the lateral spine on the seeond segment of the same exopodite, and in the form of the segment and the terminal processes of the second segment of the left exopodite. The 30 -S. \& A. 
most noticeable point of difference, however, and the one that at once separates this species from the others of the signicauda group, is the form of the appendage of the antepenultimate segment of the right male antenna.

\section{DIAPTOMUs tRyboni Lilljeborg.}

Plate XXVIII, figs. 1-4.

1859. Diaptomus Trybomi DeGnerne and Richa॰d (Lillj.), p. 58 ; pl. I, fig. 35 ; pl. II, fig. 6 ; pl. III, fig. 14 ; pl. IV, fig. 28.

1895. Diaptomus Trybomi Herrick and Turner, p. 57; pl. VIII, fig. 17 ; pl. IX, fig. 4 ; pl. X, fig. 13.

1897. Diaptomus Trybomi Schacht, p. 158; pl. XXXI, figs. 1-5.

"Of moderate size. Cephalothorax with greatest width at about the middle; last two thoracic segments distinctly separated, and the last of these as seen from above slightly produced laterally, armed with two spines (one minute) on each side; besides, on the right side of this segment appears a large dorsal appendage, triangular in form, mucronate at the apex, and produced towards the right side. The first abcominal segment of the female is especially characteristic of the species (in the male it is formed in the ordinary manner), as in $D$. signicauda asymmetrical, surpassing in length the rest of the abdomen. On the anterior part this segment is armed with a short mucronate lateral process on either side, and on the posterior part with a large triangular process extending almost directly to the right and slightly acuminate at the apex. The furcal rami are quite short, not twice as long as broad.

"The first pair of antennae of the female are 25-segmented, hardly reaching the base of the furca. The antepenultimate segment of the prehensile antenna of the male is armed with a straight and quite slender process, almost reaching the middle of the penultimate segment, and provided on the outside to the apex with small teeth. 
"The exopodite of the fifth pair of feet of the female is twosegmented, with the unguiform process of the second segment slightly curved, robust, denticulate on the middle part of the inner margin, the last teeth being broader and spine-like. The third segment is wanting and is represented only by two spines, the outer half as long as the inner. Endopodite one-segmented, hardly equal to the first segment of the exopodite, with the apex obliquely acuminate, provided with two quite long subequal spines.

"The second segment of exopodite of right foot in male is very long, surpassing in length the first segment and the basal segment taken together. The marginal spine of this segment is placed within the middle. The terminal hook is slightly curved, with the inner margin denticulate. The endopodite is curved, ovate, broad, turning inward, mucronate at the apex, hardly reaching the end of the first segment of exopodite. In the left foot, the first and second segments of the exopodite are setose within, the second obovate, hairy towards the apcx, and bearing two short spines, one of which turns inward. The endopodite is one-segmented, slender, equaling in length the first segment of the exopodite.

"Length of female, about $1.5 \mathrm{~mm}$. ; length of male, $1.4 \mathrm{~mm} . "$

The above is the description as given by DeGuerne and Richard. It is added that the species was found in great numbers at "Multrooma Falls," Oregon. As Schacht suggests, it is probable that the locality is Multnomah Falls.

DIAPTOMUS DORSALIS sp. nov.

Plate XXIII, figs. 8, 9. Plate XXIV, figs. 2, 3, 5, 6.

A small species. The first segment of the cephalothorax considerably exceeds in length the three following. The last two cephalothoracic segments are confluent. The fifth segment has two dorsal teeth, the first of which is the more prominent and projects backward; the second is rounded and undulate on its anterior margin. The last segment bears two minnte lateral spines. 
The first abdominal segment of the fenale is slender and about once and a half as long as the rest of the abdomen. It is dilated in front and laterally. The lateral expansions are well forward, and are terninated with lateral spines. The seeond segment is short, less than one-half the length of the third. The furcal rami are much longer than the third segment, and much wider at the distal than at the proxinal end. They are setose on the inner margin.

The antennae are 25-segmented and slightly exceed in length the furcal rami. The antepenultimate segment of the right antenna of the male bears a hook which is considerably shorter than one-half of the penultimate segment.

The first basal segments of the female fifth feet are armed with small spines. The second basal segments hare short lateral hairs. The exopodite consists of three sezments. The third segment is very small, and is tipped with a spine. There is also a small spine on the distal outer angle of the second segment. The second segment is prolonged into a rather biunt hook which is denticulate on the inner margin. The endopodite is shorter than the first segment of the exopodite, and is tipped with small hairs. The two terminal spines are very small.

The first basal segments of the male fifth feet are armed with prominent spines. The lateral hairs of the second basal segments of both feet are situated near the distal end of the segment. The length and breadth of these segments are about equal, and both are strongly eurved on the inner margins. From the middle of the immer margin of the second basal segment of the right foot extends a small quadrangular hyaline lamella. The first segment of the exopodite of the right foot is short, its length and breadth being about equal. On its posterior surface are two hyaline shelf-like projections. The second segment is considerably longer than the combined lengths of the second basal segment and the first segment of the exopodite. Its outer margin is strongly curved. The lateral spine is large, strongly curved, and situated about midway of the length of the segment. From near the base of the lateral spine a transverse 
ridge extends across the posterior surface of the segment. The terminal hook is falciform and nearly equals in length the whole right foot. The endopodite is small and slender, considerably exceeding in length the first segment of the exopodite.

The left fifth foot in length reaches the distal extremity of the first segment of the exopodite of the right foot. The first segment of the exopodite is somewhat longer than broad and is armed on its inner margin with small hairs. The second segment is almost cireular in outline, and also has the inner margin setose. It is tipped with a finger-like process and with a longer slender spine. The endopodite is slender, somewhat conical in shape. and reaches to about the middle of the second segment of the exopodite.

Length of female, $1.1: 3 \mathrm{~mm}$. Length of male, $1.069 \mathrm{~mm}$.

This species was found in collections made by Professor Birge at Guzman and Milneburg, Louisiana. In the Guzman collections it was associated with $D$. mississippiensis. The form of the male fifth feet, however, and the dorsal process of the female make it easy to distinguish the two species. The particularly distinguishing features of $D$. dorsalis are the hyaline appendages of the segments of the right male fifth foot, and this dorsal process. The process very probably resembles that in D. gibber Poppe, but as DeGuerne and Richard give no figure, one cannot be certain.

Diaptomus saltillinus Brewer.

Plate XXIII, figg. 4, 6, 7, 10. Plate XXIV, fig. 1.

1897. Diaptomus albuquerquensis Schacht, p. 146; pl. XXVII, figs. 2, 4 .

1898. Diaptomus saltillimus Brewer, p. 12 $;$; pl. VII, figs. 5-9. 1905. Diaptomus saltillinus Pearse, p. 148; pl. XIV, figs. : 10.

Of molerate size. The first cephalothoracic segnnent equals in length the three following. The last cephalothoracic segment is expanded in lateral lobes, each of which bears two minute 
spines. The fifth segment of the female has a projecting tooth at the middle of the dorsal surface.

The first abdominal segment of the female exceeds the rest of the abdomen in length. It is nuch dilated in front. The lateral dilatations are rather slight, at the proximal fourth of the length, and armed with minute spines. The second and third segments are about equal in length, and each is somewhat shorter than the furea. The furcal rami are longer than broad and ciliate on the inner margin.

The antennae are 25 -segmented and reach to the end of the furea. The right antemna of the male is much swollen anterior to the geniculating joint; the antepenultimate segment bears a stont hook which is abont one-half the length of the penultimate segment.

The spines on the posterior surface of the first basal segments of the female fifth feet are prominent. The lateral hairs of the second basal segments are slender. The length of the first segment of the exopodite is more than twice its width. The second segment is prolonged into a hook of slight curvature, and is denticulate on the inner margin. The third segment is distinct and armed with two spines. The endopodite is one-segmented, about one-half the length of the first segment of the exopodite, and setose at the tip.

The first basal segments of the fifth feet of the male are each armed with a prominent slender spine as in the case of the female fifth feet. The second basal segment of the right foot is as broad as long. It has a tooth-like process at the middle of its inner margin and a small hyaline process on the posterior surface near the distal end of the segment. The lateral hair is near the distal end. The first segment of the exopodite is short, its length being a little more than one-half its breadth. It is produced at the outer distal angle, and bears a small fold on the posterior surface near the distal end. The second segment is stout, its length being to its breadth in the proportion of three to two. The lateral spine is situated towards the distal end, is straight, and equals in length the two segments of the exopodite. The terminal hook is slender, and so 
sharply curved at the middle that the two parts make very nearly a right angle with each other. Its length equals that of the whole right foot. It is finely denticulate on the proximal half of the inner margin. The endopodite is short, stout and pointed, equaling in length the first segment of the exopodite. It is setose at the tip. The left foot reaches beyond the middle of the second segment of the right exopodite. The second basal segment is longer than broad, and nearly equals in length the corresponding segment of the right foot. The lateral hair is near the distal end. The first segment of the exopodite is twice as long as wide, and setose on the inner margin. The second segment is spherical in form, setose on its inner margin, and is terminated by a setose finger-like process and a slender faleiform spine. The endopodite is slender, equal in length to the first segment of the exopodite, and setose at tip.

Length of female, $1.5 \mathrm{~mm}$. Length of male, $1.25 \mathrm{~mm}$.

Locality, temporary pools near Lincoln, Nebraska.

If $D$. albuquerquensis Schacht is identical with $D$. saltillinus, this species is also found in Florida. The relationship of $D$. albuquerquensis Schacht to D. saltillinus is discussed under $D$. alburuerquensis.

diaptones albuquerquensis Herrick.

Plate XXIV, figs. 4, ヶ-10. Plate XXV, fig. 1.

1895. Diaptomus albuquerquensis Herrick, p. 45 ; figs. 16-26. 1895. Diaptomus albuquerquensis Herrick and Turner, p. 67; pl. VI, figs. 1-3; pl. VII, figs. 1-11.

1904. Diaptomus Lehmeri Pearse, p. S89; figs. 1-4.

Of moderate size. The cephalothorax is broadest at tha middle. The first segment is abont equal in length to the three following. The last segment in the female bears a blunt dorsal tooth; the segment is expanded lateraliy, each wing bearing two rather prominent spines.

The first abdominal segment of the female equals in length the remainder of the abdomen and the furca; it is dilated lat- 
erally and in front, and bears a stroug spine on each side. 'The second segment is short, being only about one-half the length of the third. The third segment and the furcal rami

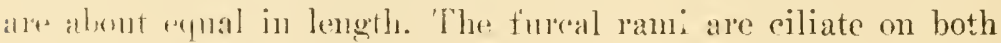
the inner and outer margins.

The antennae are 25 -segmented, and reach to the end of tho furca. The right antenna of the male is much swollen anterior to the genienlating joint; the antepenultimate segment bears a slightly recurved hook considerably less in length than the penultimate segment. In the female fifth feet, the spines of the first basal segments are pronounced. The first segment of the exopodite is abont twice as long as wide. The lrook of the second segment is nearly as long as the first segment, is slightly cmrved, and is denticulate on the inner margin. The hook has a single fine tooth on the outer margin. There is a small spine at the base of the third segment. The third sogment is distinet, and bears two spines of which the inner is the longer. The endopodite is indistinctly two-segmented, and is about one-half the length of the first segment of the exopodite. It is setose at tip.

In the male fifth feet, the spines of the first basal segments are stont. The length of the second basal segment is somewhat less than twice its width; it is trapezoidal in form, and wider at the distal end. The lateral hair is situated elose to the distal end of the segment. The proximal inner angle is expanded into a wing-like process. At a little less than one-half its length, there is on the inner margin a recurved hyaline tooth. On the posteriou surface of the segment is a two-headed hyaline process. The first segment of the exopodite is short, its length being only about one-half its width. The onter distal angle is somewhat extended. The segment has a hyaline lamella on its posterior surface, and a small hyaline projection from its posterior distal border. The second segment of the exopodite is between three and four times as long as the first segment. The lateral spine is situated at about four-fifths of its lengtl, is long, nearly straight, and finely denticulate on its inner margin. On the posterior surface of the segment, 
about midway of its length, is an oblique ridge. The terminal hook is longer than the rest of the foot, regularly curved and finely denticulate on the inner margin. The right endopodite is one-segmented, about equal in length to the first segment of the exopodite, and is setose at the tip.

The left foot reaches beyond the end of the first segment of the exopodite. The secoud basal segment is elongate, but shorter than the corresponding segment of the right foot. The lateral hair is situated at rather more than two-thirds the length of the segment. The first segment of the exopodite is about twice as long as wide; the inner margin is convex and setose. The second segment of the exopodite is about equal in length and width; it is terminated by a blunt process and a slender, eurved spine; its inner margin has two setose pads. The endopodite is slender, one-segmented, equal in length to the first segment of the exopodite, and setose at the tip.

Length of female, $1.765 \mathrm{~mm}$. Length of male, $1.581 \mathrm{~mm}$.

Localities: Albuquerque, New Mexico, City of Mexico, and Hugo, Colorado.

It was found impossible to get authoritative examples of this species, as the material was not preserved by Herrick, and the author was unsuccessful in dredging in the same locality. The description is from the material obtained in pools near Hugo, Colorado. Herrick does not mention or figure the tooth on the inner margin of the first basal segment of the right fifth foot of the male, or the dorsal tooth on the cephalothorax of the female. While it is possible that these features, which were not described either by Pearse, are local variations, it does not seem probable, inasmuch as the correspondence is so complete as far as the published descriptions go. It seems probable that these features were overlooked.

It may be noticed that $D$. albuquerquensis, $D$. dorsalis and $D$. saltillinus are very closely related to each other, and it is possible that intermediate forms may be found.

Schacht describes D. alluquerquensis from naterial collected in Florida. Just what Schacht had it is pretty difficult to tell, as he gives only two tignu'es, but it seems evident that $D$. albu- 
querquensis Herrick and $D$. albuquerquensis Schacht are not identical. The figure of the male fifth foot given by Schacht is very different from that figured by Herrick, and I think it probable that it belongs to $D$. saltillinus Brewer. The figure of the female fifth foot is of neither $D$. saltillinus nor $D$. albuquerquensis, as both species have a short endopodite. Schacht states that his $D$. albuquerquensis was found in connection with D. mississippiensis, and his figure would correspond very well to the fifth foot of the female of that species. It seems probable, then, that Schacht's description is a composite of $D$. saltillinus and D. mississippiensis, and that he had no specimens of $D$. albuquerquensis.

DIAPTOMUS ASYMMETRICUS sp. nov.

\section{Plate XXV, fig. 6. Plate XXVI, figs. 1. 3, 4.}

A small species. The first cephalothoracie segment is longer than the three following. The second, third and fourth segments are abont equal in length, the fifth somewhat longer. The lateral expansions of the last thoracic segment are armed on each side with an acute spine.

The first segment of the female abdomen is much longer than the rest of the abdomen. It is expanded laterally at a little less than one-third its length; the dilatations are armed with acute spines which are slightly recurved. The dilatation on the front of the segment is rery pronomned. At about two-thirds the length of the segment, and on the right side, is a blunt, rounded projection, which is much more prominent than the lateral dilatation. The second segment is short. The third segment is fully four times as long as the second, and is about equal in length to the furca. The distal end of the furcal ramus is nearly twice as wide as the proximal; the furcae are ciliate on the inner margin.

The antennae are 25 -segmented, and in the female extend beyond the tip of the furcae. The right antenna of the male is much swollen anterior to the geniculating joint. The an- 
tepenultimate segment bear's a recurved, hook-shaped process, which is about one-half the length of the penultimate segment; on the outer surface of this hook, and extending down the segment, is an inconspicnous lyyaline lamella.

The first basal segments of the female fifth feet are armed with long and rather slender spines. The lateral hairs of the second basal segment are short and weak. The exopodite consists of three segments. The first segment is more than twice as long as its width. The second segment has a small spine on the outer distal angle; its inner margin is only slightly curved and is finely denticulate. The third segment is distinct and bears two spines, of which the inner is the longer. The endopodite is shorter than the first segment of the exopodite, and is one-segmented, or indistinetly two-segmented; its tip is setose, two of the setae being especially prominent, but hardly large enough to be called spines.

The spines of the first basal segments of the male fifth feet are long and acute. The second basal segment of the right foot is rectangular and longer than broad; the lateral hair is near the distal end of the segment; on the inner margin, about midway of its length, is a prominent hyaline projection with a semi-elliptical outline. The first segment of the exopodite is short, its length being to its breadth as one to one and one-half; on the posterior surface is a ridge running from the inner margin to about the middle of the segment. The second segment of the exopodite is slightly longer than the combined length of the second basal segment and the first segment of the exopodite; the outer margin is angular; the lateral spine is stout, slightly sigmoid, and is situated just beyond the angle near the end of the proximal haif of the segment; on the posterior surface of the segment, nearly opposite the distal edge of the lateral spine, is a curved transverse ridge extending nearly across the segment. The terminal hook is strougly curved, falciform, slightly longer than the rest of the exopodite and the first basal segment, and is finely denticulate on the inner margin. The endopodite is one-segmented, about twice as long as the first segment of the exopodite, and is setose at the tip. 
The left fifth foot reaches to about one-third the length of the second segment of the right exopodite. The second basal segment is trapezoidal, its proximal end being the wider; the lateral hair is near the distal end. The first segment of the exopodite is longer than broad, the inner and outer margins convex, and the inner margin setose. The inner margin of the second seg,nent is a semicircular setose pad; the segment is terminated with a slender digitiform process and a long and slender spine, the two forming a forcipate structure. The endopodite is slender, one-segmented, longer than the first segment of the exopodite, and setose at the tip.

Length of fcmale, $1.39 \mathrm{~mm}$. Length of male, $1.16 \mathrm{~mm}$. This species was found in rollections made by Prof. C. F. Baker at Havana, Cuba.

DIAPTOMUS PURPUREUS sp. nov.

Plate XXV, figs. 4, 7. Plate XXVI, figs. 2, 5.

A large species. The first segment of the cephalothorax equals the three following. The second, third and fourth are about equal in length, the fifth somewhat longer. The laterai expansions of the last cephalothoracic segment are armed on each side with a small, acnte spine.

The first segment of the female abdomen is longer than the rest of the abdomen. The lateral dilatations are near the proximal end of the segment, are not narked, and are armed with small, acute spines. The second segment is short, being only about one-quarter the length of the third. The third segment and the furca are nearly equal. The distal ends of the furcal rani are wider than the proxinal; the inner margins are ciliate.

The antemnae are 25-spgmented, and in the female barely reach the end of the first abdominal segment. The right antenna of the male is much swollen anterior to the geniculating. joint; the antepenultimate segment bears a recurved, hookshaped process which is about one-lialf the length of the penul- 
timate segment. On the outer surface of the hook, and extending down the side of the segment, is an inconspicuous hya line lamella.

The first basal segments of the female fifth feet are armed with long and stont spines. The lateral hairs of the second basal seginents are short and weak. The exopodite consists of three segments; the first segment is stout, its length being to its breadth as four to two and one-half. The second segment has a small spine on its outer distal angle; the inner margin of the hook is concave and armed with prominent teeth. The third segment is distinct and bears two spines, of which the inner is the longer: The endopodite is one-segmented, is more than one-half the length of the first segment of the exopodite, and at the tip is setose and bears two long spines and one small one.

The spines of the first basal segments of the fifth feet of the male are acute and rather small. The second basal segment is trapezoidal in its general outline, longer than broad, its distal end the broader, and is distinctly convex on its inner and outer margins; the lateral hair is small and is near the distal end; on the inner margin. beyond the middle, is a hyaline projection with a rounded ontline. The first segment of the exopodite is wider than long, and bears on its posterior face at about two-thirds of its length a transverse ridge. The second segment of the exopodite is a little more than twice as long as wide, and approximately rectangular in form; about midway of the posterior surface is a short, curved ridge; at the middle of the posterior surface, near the onter margin, is a semi-circular hyaline projection; the lateral spine is near the distal end of the segment; the terminal hook is about as long as the rest of the right foot exclusive of the first basal segment, is slender, and bent at near its middle into very nearly a right angle; the denticulations of its inner margin are very fine. The endopodite of the right fifth foot is short and stout, barely exceeding one-half the length of the first segment of the exopodite, and is setose at the tip. 
The left foot reaches to one-half the length of the second segment of the right exopodite. The secoud basal segment is long and rectangular, equaling in length the corresponding segment of the right foot, but is not so wide; the lateral hair is situated not far from the distal end of the segment. The first segment of the exopodite is twice as long as wide, of nearly the same width through its whole length, the inner and outer margins slightly convex, the inner margin setose. The second segment is conical in form, with a rounded ciliate pad on its inner margin; the segment terminates in a blunt digitate process. The endopodite of the left fifth foot is one-segmented and shorter than the first segment of the exopodite; it is setose at the tip.

Length of female, $2.56 \mathrm{~mm}$. Length of male, $2.24 \mathrm{~mm}$.

This was collected by Prof. C. F. Baker in Havana, Cuba, and was found associated with $D$. asymmetricus.

The species is very conspicuous, for, in addition to being of large size, the furcae, the furcal setas and the distal ends of the antennae are colored a deep purple.

\section{diaptomus sajguineus Forbes.}

$$
\text { Plate XXVt, figs. 2, 5, } 8 .
$$

1876. Diaptomus sanguineus Forbes, pp. 15, 16, 23; figs. 24, 28-30.

1882. Diaptomus sanguineus Forbes, p. 647; pl. VIII, figs. 1-7, 13 .

1884. Diaptomus sanguineus Herrick, p. 138; pl. Q, fig. 12. 1884. Diaptomus minnetonka Herrick, p. 138; pl. Q, figs. 8-10.

1889. Diaptomus sanguineus DeGuerne and Richard, p. 20; figs. $9-11$; pl. IV, fig. 24.

1893. Diaptomus sanguineus Marsh, p. 195; pl. III, figs. 1-3. 1895. Diaptomus sanguineus Herrick and Turner, p. 71; pl. $\mathrm{V}$, figs. 8,9 ; pl. XIII, fig. 12.

1895. Diaptomus minnetonka Herrick and Turner, p. $71 ; \mathrm{pl}$. XIII, figs. 8-10. 
1897. Diaptomus sanguineus Schacht, p. 133; pls. XXIII, XXIV, XXV.

1898. Diaptomus sanguineus Brewer, p. 124.

1905. Diaptomus sanguineus Pearse, p. 147.

Rather large. The first segment of the cephalothorax is nearly equal in length to the rest of the cephalothorax. The last segment of the cephalothorax is produced laterally, and armed on each side with two rather prominent spines. The fifth cephalothoracic segment of the fernale has a pronounced dorsal hump.

The first abdominal segment of the female equals the rest of the abdomen including the furca. It is expanded laterally and in front, and bears two pronounced lateral spines. The second segment is about one-half as long as the third. The furcal rami are setose on the inner margin.

The antennae are 25-segmented and somewhat longer than the eephalothorax. The right antenna of the male is much swollen anterior to the geniculating joint. The antepenultimate segment bear's at its distal end a short, stout, recurved hook, which is continuons with a lateral hyaline lamella of the segment.

The female fifth feet are rather stout. The spines of the first basal segments are of moderate size. The lateral hairs of the second basal segments are commonly long, reaching nearly to the end of the first segment of the exopodite. The first segment of the exopodite is twice as long as broad. The second segment is produced into the customary hook, which is dentate on the inner margin. The third segment is represented by two spines, of which the outer is the shorter. The endopodite is slender, variable in length, but commonly much shorter than the first segment of the exopodite. It is setose at tip, and armed with two rather long spines.

In the male fifth feet, the spines of the first basal segments are rather small. The second basal segment of the right foot is trapezoidal in form, wider at the distal end. Its length is about twice its average width. The outer distal angle is prolonged into a blunt or acute spine; the lateral hair is near the 
distal end. The first segment of the exopodite is small and quadrate. The second segment has about the same width as the first, and its length is abont that of the second basal seg ment. Its outer margin is convex and its inner sinuous. The lateral spine is situated at about two-thirds the length of the segment, and is commonly straight and rather weak. The terminal hook is falciform with a regular curve, is denticulate on the inner margin, and is about equal in length to the second segment of the exopodite. The right endopodite is short and stout, much shorter than the first segment of the exopodite, setose at tip. Frequently the joint between it and the second basal segment disappears, and the endopodite appears simply as a prolongation of the inner distal angle of the second basal segment.

The left fiftl foot reaches to the end of the second basal segment of the right foot. The second basal segment is quadrate, its inner margin strongly convex. The lateral hair is situated at the onter distal angle, is stont and phumose. The first segment of the exopodite is small and trapezoidal, widest at the base. The second segment is twice the length of the first. armed on its inner surface with a hemispherical setose pad. It terminates in two curved spines forming a forcipate structure. The inner spine is movable, bears a small tubercle on the inner side of its base, and is setose. The endopodite is about three times as long as broad, longer than the first segment of the exopodite, and is setose at tip.

Length of female, 1.4 to $2.12 \mathrm{~mm}$. Length of male, 1 to $2 \mathrm{~mm}$. (Schacht).

Occurs only in the early spring in stagnant pools. It is found quite generally in the Mississippi valley. It has been found as far east as New York, as far north as Wisconsin and Minnesota, as far west as Nebraska, and as far south as Alabama.

D. sanguineus is a very variable species. Some of these variations have been discussed in some detail by Schacht. The variations do not seem to be so great, huwever, as necessarily to raise any question as to specific identity. Inasmuch as there 
is a succession of forms in some pools in the spring, Herrick has maintained a heterogenetic character of this species, but his conclusions have not been verified by other authors. The ex: gencies of the life of the species may explain its variability. From the fact that its life is so short, we might expect some localization of species, inasmuch as there is hardly time for dispersion in the ordinary ways, and it is very possible that extended study will show that there are very definite local varieties.

Schacht considers $D$. armatus Herrick a variety of $D$. sanguineus. While I think this identification is probably correct, I have not ventured to include this among the list of synonyms, for Herrick's description is so very meager that it is impossible to know what form he had before him.

DiAptomus EIseni Lilljeborg.

Plate XXV, fig. 3. Plate XXVI, figs. 6, 8.

1๕89. Diaptomus Eiseni DeGuerne and Richard, p. 44; pl. I, figs. $19,29,33$.

1895. Diaptomus Eiseni Herrick and Turner, p. 58; pl. X, fig. 11.

1897. Diaptomus Eiseni Schacht, p. 162.

1898. Diaptomus Eiseni Brewer, p. 128; pl. VII, figs. 9-12.

Among the largest of the genus. The cephalothorax is widest at the posterior part of the head. The first segment does not equal in length the rest of the cephalothorax. The last two thoracic seginents are commonly confluent above, or indistinctly separated. The lateral lobes of the last segment, seen from above, are, in the female, short, the anterior and posterior angles somewhat acute, and the lateral obtuse. The lateral spines of the last segment are short and thick.

The first abdominal segment of the female equals or exceeds in length the rest of the abdomen including the furca. It is swollen laterally and in front, and bears on the lateral expansions rather large spines which project backwards. The second 31-S. \& A. 
segment is very short, and the third and the furea are nearly equal in length. The furcal rami are ciliate on both inner and outer margins.

The antennae are 25 -segmented, and in the female reach the lateral processes of the first abdominal segment. The antepenultimate segment of the right male antenna has a long, recurved, acuminate process, which reaches about to the end of the antenna.

In the fifth foot of the female, the first segment of the exopodite is twice as long as wide. The second segment is prolonged into the customary hook. This segment bears a spine at its outer angle and is denticulate on its inner margin. The third segment is distinct and bears two strong spines, of which the inner is longer and is serrate on its margins.

The endopodite nearly equals in length the first segment of the exopodite, is indistinctly two-segmented, is setose at tip, and bears two rather long spines.

In the fiftl feet of the male, the spines of the first basal segments are rather small. The second basal segment of the right foot is wider than long, has a peculiar rugose expansion of the inner margin, and bears the lateral hair at about twothirds of its length. The first segment of the exopodite is short, its length being less than its breadth. It is produced on the outer distal angle, and bears a small tubercle on the inner margin near the distal end. The second segment is twice as long as broad, convex on the onter margin, and concave on the inner. The lateral spine is placed near the onter distal angle and is serrate on the inner side. The terminal hook is about as long as the whole right foot exclusive of the first basal segment; it is abruptly bent at somewhat less than half its length, making very nearly a right angle. The inner margin is dentate. The endopodite is slender, indistinctly two-segmented, and once and a half as long as the first segment of the exopodite. The left foot reaches nearly to one-half the length of the second segment of the right exopodite. The second basa. segment is as long as wide, with the lateral hair placed near the distal cul. Thie first segment of the exopodite is twiee as 
long as wide, convex on both inner and outer margins, and with the imner margin setose. The second segment is slightly longer than the first, and armed with two setose pads on its imner margin. It terminates in a blunt digitiform process, and from the imner margin projects an acmminate, curved spine. The endopodite is slender, indistinctly two-segmented, reaches abont one-half the length of the second segment of the exopodite, and is setose at tip.

Length of female, $4 \mathrm{~mm}$. Length of male, $3.5 \mathrm{~mm}$.

The original description was from material found in Fresno, California. It was later reported by Brewer from Lincoln, Nebraska. These are thus far the only localities for the species, but donbtless it will he found at intermediate points.

The description, as given above, is largely a compilation from DeGuerne and Richard and Brewer, with snch modificacations as a very limited persomal acquaintance with the species has permitted.

In the plate, the fignres of the antenna and fomale fifth foot are from DeGuerne and Richard, the male fifth foot from a preparation kindly loaned by Professor H. B. Ward.

Diaptomes movamexicanus Merriek.

Plate XXVI, figs. 9, 10.

1895. Diaptomus nocamexicamus Herricts, p. t6, figs. 27-29. 1895. Diaptomus novamexicanus Herrick and Turner, p. 70; pl. VI, figs. 7-10.

1897. Diaplomus novamexicanus Schacht, p. 149.

"A small species of robust form. Cephalotloorax widest in front of the middle. The first segment equals in length the rest of the eephalothorax. The last segment is armed on each side with a minnte spine.

"The first abdominal segment of the female exceeds in length the rest of the abdonen. It is dilated laterally, and armed on each side with a small spine. The second segment is very short. The fureal rauni efural in length the preeding segment. The furcal setae are short. 
"The antennae are 25-segmented and reach the furca, or sometimes the end of the furca. The right antenna of the male is swollen anterior to the geniculating joint; the antepenultimate segment lias a lateral lamina which is prolonged at the end of the segment into a hook which barely reaches the end of the penultimate segment.

"In the female fifth foot, the spines of the first basal segments are large. The second segment of the exopodite has a strongly enrved look, which is denticulate on the inner margin. The third segment of the exopodite is distinct, and bears two spines. The endopodite is one-segmented, hardly equaling in length the first segment of the exopodite; the tip is armed with two spines and is setose.

"In the male fifth feet, the spines of the first basal segments are large. The second basal segment of the right foot is quadrate, rather longer than broad. The first segment of the exopodite is quadrate and shorter than the second basal segment. The second segment of the exopodite is three times as long as broad, convex on the outer margin and concave on the inner. The lateral spine is at about two-thirds its length, and is rather short. The terminal hook is symmetrically curved and nearly equal to the combined length of the rest of the exopodite and of the second basal segment. Thie right endopodite is one-segmented, setose at tip, and equal in length to the first segment of the exopodite.

"The left fifth foot of the male reaches the end of the first segment of the right exopodite. The first segment of the exopodite is oval. The second segment is nearly equal in length to the first; it terminates in two strong spines, and has a setose lamina at its base on the inner margin. The endopodite is onesegmented, setose at tip, and reaches to the middle of the second segment of the exopodite. The animal is for the most part colorless, but sometimes is blue or red.

"Length of female, 1.1 to $1.2 \mathrm{~mm}$."

Locality, the tank of the eity works at Albuquerque, New Mexico.

The abovo is the description of Herrick, and the figures of 
the plates are copies from his paper. I have been unable to obtain any material in order to verify the rescription.

\section{LIST OF PAPERS QUOTED.}

Beardsley, A. E., '02: Notes on Colorado Entomostraca. Trans. Amer. Micr. Soc., xxiii: 41-48.

Brewer, A. D., '98: 1 study of the Copepoda found in the vicinity of Lincoln, Nebraska. Jour. Cincinnati Soc. Nat. IIist., xix: 119-146.

DeGueirse, J., and Richard, J ', '89: Révision de Calanides d' eau donce. Mem. Soc. Zool. de France, ii.

__, '92: Sur la Faune des eau donces de l' Islande. Bull. Soc. Ent. Fr., 8 fev., 1892.

Forbes, S. A., '82: On some Entomostraca of Lake Michigan and adjacent waters. Amer. Nat., xvi: 537-542, 640-649.

-, '91: On some Take Superior Entomostraca. Rept. $U$. S. Fish Com., 1887, pp. 701-718.

- '93: A preliminary report on the aquatic invertebrate fauna of the I'ellowstone National park, Wyoming, and of the Flathead region of Montana. Bull. U. S. Fish Com., 1891, pp. 207-25s.

Herrick, C. L., '79: Microscopic Entomostraca. Ann. Rept. Regents Univ. Minn., 1878, pp. 81-123.

'82: Papers on the Crustacea of the fresh waters of Minnesota. Ann. Rept. Geol. and Nat. Hist. Survey Minn., x: 221-254 +i-ii.

_ s:3: Heterogenetic development in Dirptomus. Amer. Nat., xvii: 351-389, 499-505.

-__, $s 4$ : A final report on the Crustacea of Minnesota includel in the orders Cladocera and Copepoda. Ann. Rept. Geol. and Nat. Hist. Survey Minn., xii.

-_, '95: Micro-Crustacea from New Mexico. Zool. Anz., xviii : $40-47$.

Herrick, C. I., and Turver, C. H.. '95: Synopsis of the Entomostraca of Minnesota. Geol. and Nat. Hist. Survey Minn., 2nd Rept. State Zoologist. 
Judar, C., '03: The plankton of Winona lake. Ind. Univ. Bull., i: 120-133.

Marsh, C. D., '91: On the deep-water Crustacea of Green lake. Trans. Wis. Acad., viii: 211-213.

- '93: On the Cyclopidæ and Calanidæ of Ceutral Wisconsin. Trans. Wis. Acad., ix: 189-224.

—, '94: On two new species of Diaptomus. Trans. Wis. Acad., ix: 15-17.

- '95: On the Cyclopidx and Calanidie of Lake St. Clair, Lake Michigan, and certain of the inland lakes of Michigan. Bull. Mich. Fish Com., no. 5.

- '97: The limnetic Crustacea of Green lake. Trans. Wis. Acad., xi : 189-224.

- '03: The plankton of Lake Winnebago and Green lake. Wis. Geol. and Nat. Hist. Survey, Bull. xii.

- ' '04: Report on Copepoda, in "A biological reconnoissance of some elevated lakes in the Sierras and Rockies," by Henry B. Ward. Studies from Zool. Lab., Univ. Neb., no. $60: 146-149$.

Pearse, A. S., '04: A new species of Diaptomus from Mexico. Amer. Nat., xxxviii: S89-891.

- - '05: Contributions to the Copepod fauna of Nebraska and other states. Studies from Zool. Lab., Univ. Neb., no. $65: 145-160$.

—, '06: Fresh water Copepoda of Massachusetts. Amer. Nat., xl: 241-251.

Poppe, S. A., '88: Diagnoses de deux espèces nouvelles du genre Diaptomus Westwood. Bull. Soc. Zool. Fr., xiii: 159.

Schacht, F. W., '97: The North American species of Diaptomus. Bull. Ill. State Lab. Nat. Hist., v, art. 3. 
Marsh-North American Species of Diaptomus. $\quad 487$

PLATE $X \nabla$. 
488 Wisconsin Academy of Sciences, Arts, and Letters.

\section{EXPLANATION OF PLATE XV.}

Fig. 1. Diaptomus oregonensis: fifth feet of male $(\times 290)$.

Fig. 2. Diexptomus Reighardi: fifth feet of male $(\times 290)$.

Fig. 3. Diavtomus mississippiensis: fifth feet of male $(X 290)$.

Fig. 4. Diaptomus oregonensis: fifth feet of female $(\times 375)$.

Fig. 5. Diaptomus missiswippiensis: abchomen of female (X165).

Fig. 6. Diaptomus Reighardi: abdomen of female $(\times 290)$.

Fig. 7. Dirptomus oregonensis: abdomen of female $(\times 165)$.

Fig. 8. Diaptomus mississippiensis: fifth feet of female $(\times 290)$.

Fig. 9. Diaptomus Reighardi: fifth feet of female $(\times 375)$. 
Trans, Wis. Acad., Vol. XV.

Plate XV.

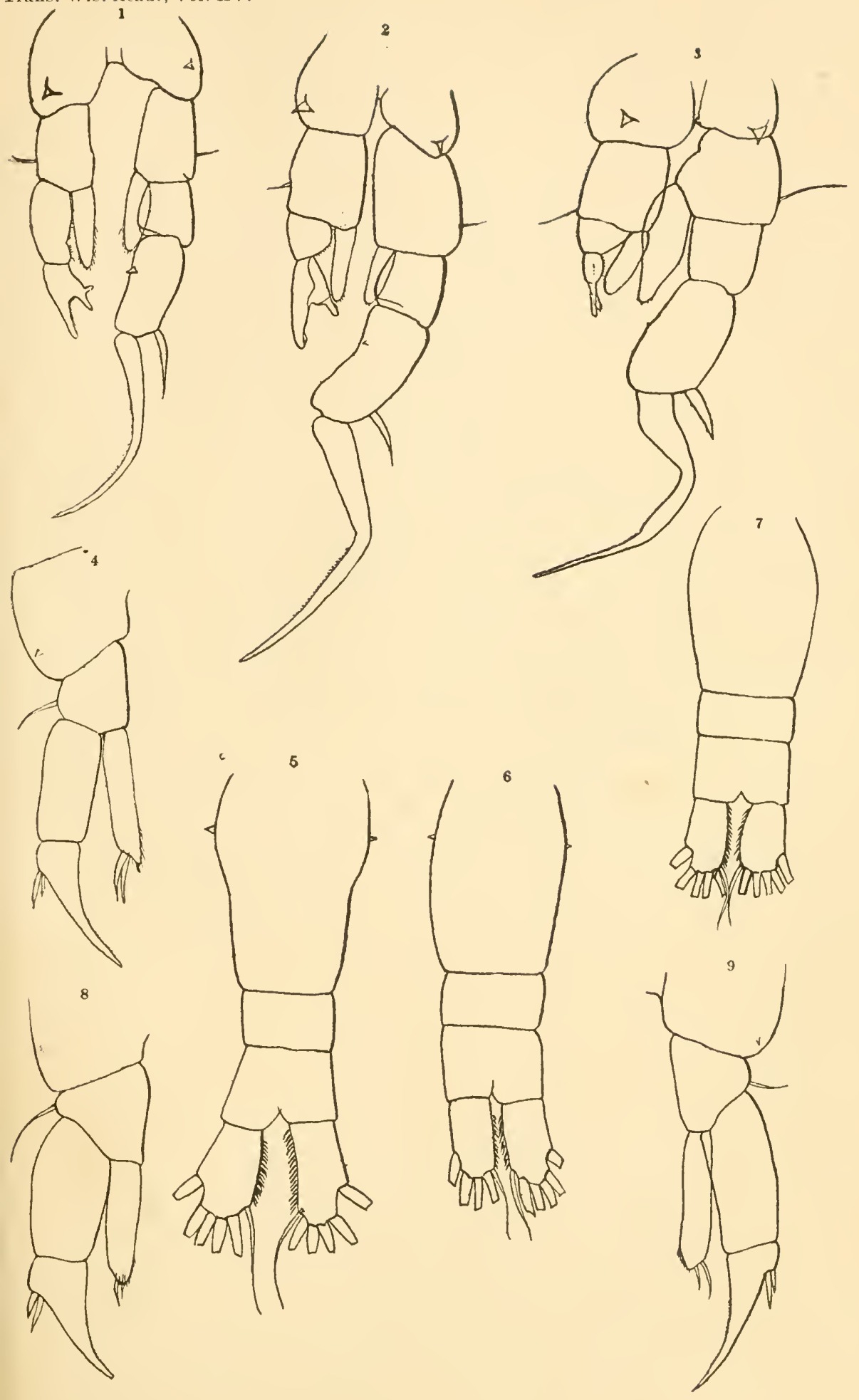

C. D. Marsh del. 

Marsh-North American Species of Diaptomus. 489

PLATE XVI. 
490 Wisconsin Academy of Sciences, Arts, and Letters.

\section{EXPLANATION OF PLATE XVI.}

Fig. 1. Diaptomus pallidus: fifth feet of male $(\times 190)$. Fig. 2. Diaptomus pallidus: abdomen of female $(\times 165)$.

Fig. 3. Diaptomus pallidus: fifth feet of female $(\times 290)$.

Fig. 4. Diaptomus Bakern: abdomen of female ( $\times 155)$.

Fig. 5. Diaptomus Bukeri: terminal segments of right antenna of male $(\times 155)$.

Fig. 6. Diaptomus Bakeri: fifth feet of male (X165).

Fig. 7. Diaptomus tenuicaudatus: abdomen of female $(\times 165)$.

Fig. 8. Diaptomus tenuicaudatus: fifth feet of male $(\times 290)$.

Fig. 9. Diaptomus Bakeri: fifth feet of female $(X 29 \mathrm{C})$. 
Trans. Wis. Acad., Vol. XV.

Plate XVI.

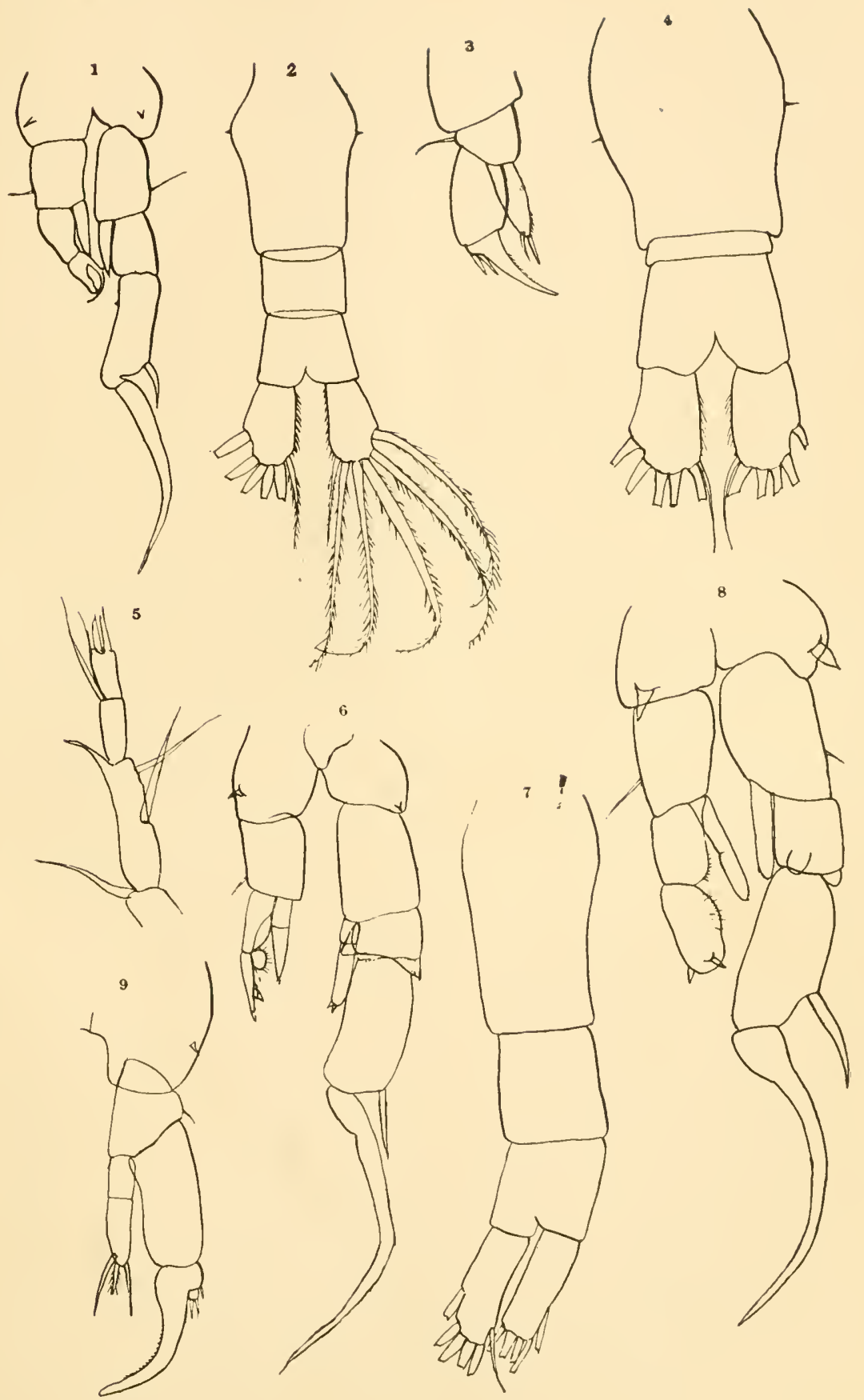

(․ I. Marsh del. 

Marsh-North American Species of Diaptomus. 491

PLATE XVII. 
492 Wisconsin Academy of Sciences, Arts, and Letters.

\section{EXPLANATION OF PLATE XVII.}

Fig. 1. Diaptomus sicilis: fifth feet of male $(\times 290)$.

Fig. 2. Diaptomus tenuicaudatus: nifth feet of female $(\times 290)$.

Fig. 3. Diaptomus tenuicaudatus: terminal segments of right antenna of male $(\times 290)$.

Fig. 4. Diaptomus sicilis: terminal segments of right antenna of male $(\times 290)$.

Fig. 5. Diaptomus sicilis: fifth foot of female $(\times 290)$.

Fig. 6. Diaptomus Ashlandi: fifth foot of female $(\times 375)$.

Fig. 7. Diaptomus minutus: fifth foot of female $(\times 375)$.

Fig. 8. Diaptemu.s Ashleandi: fifth feet of male $(\times 290)$.

Fig. 9. Diaptomus sicilis: abdomen of female ( $\times 165)$.

Fig. 10. Diaptomus Ashlandi: terminal segments of right antenna of male $(\times 290)$.

Fig. 11. Diaptomus minutus: terminal segments of right antenna of male $(\times 280)$. 
Trans. Wis. Acad., Vol. XV.
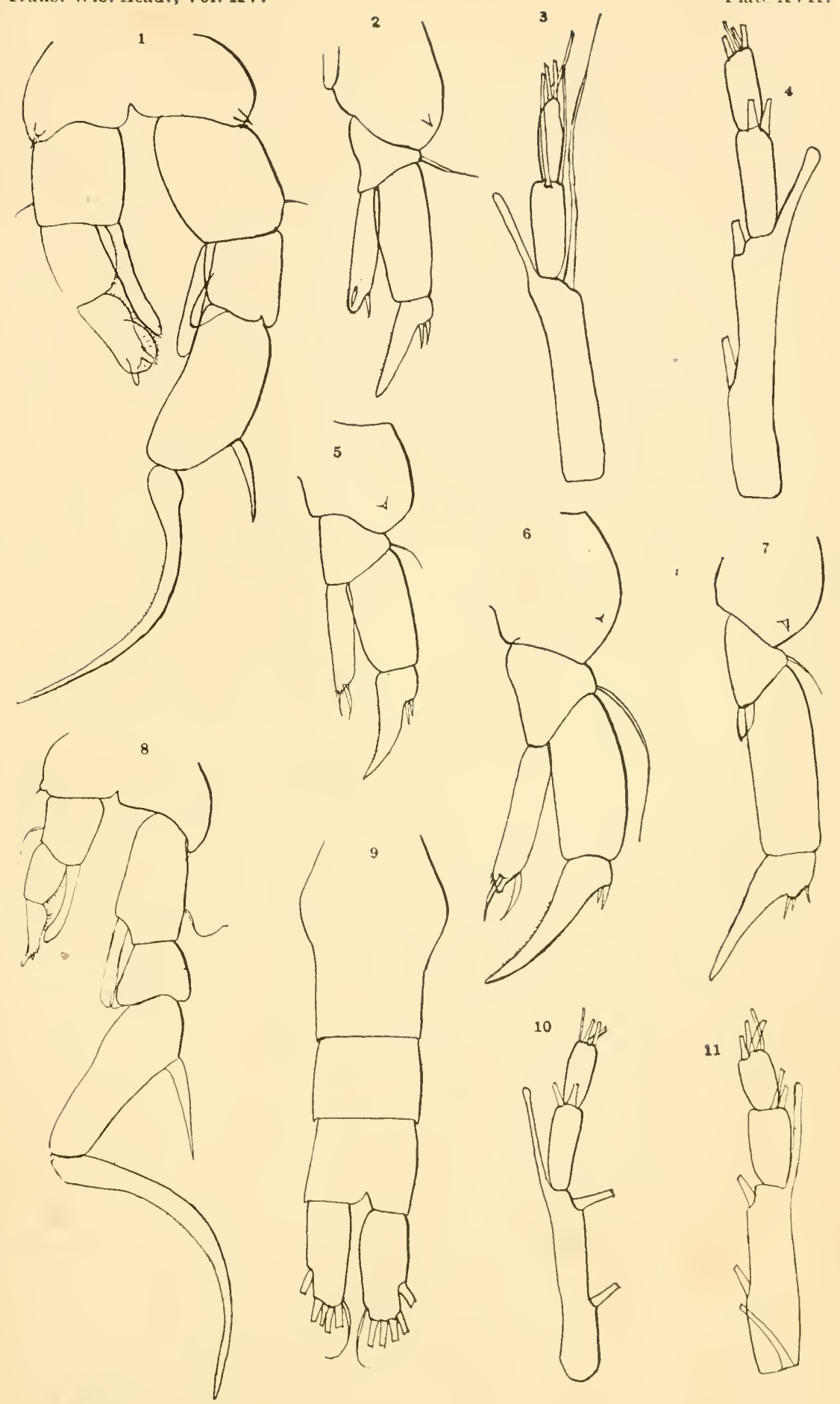

C. D. Marsh del. 

Marsh-North American Species of Diaptomus. 493

\section{PLATE XVIII.}


494 Wisconsin Academy of Sciences, Arts, and Letters.

\section{EXPLANATION OF PLATE XVIII.}

Fig. 1. Diaptomus minutus: abdomen of female ( $\times 165)$.

Fig. 2. Diaptomus shoshone: fifth feet of male $(X 108)$.

Fig. 3. Diaptomus shoshone: abdomen of female ( $X 68)$.

Fig. 4. Diaptomus shoshone: terminal segments of right antenna of male $(X 180)$.

Fig. 5. Diaptomus shoshone: fifth foot of female $(\times 108)$.

Fig. 6. Diaptomus Birgei: abdomen of female ( $\times 165)$.

Fig. 7. Diaptomus minutus: fifth feet of male $(\times 290)$.

Fig. 8. Diaptomus Birgei: terminal segments of male antenna $(\times 290)$.

Fig. 9. Diaptomus siciloides: fifth foot of female $(\times 290)$. 
Trans. Wis. Acad., Vol. $\mathrm{XV}$.

Plate XVIII.
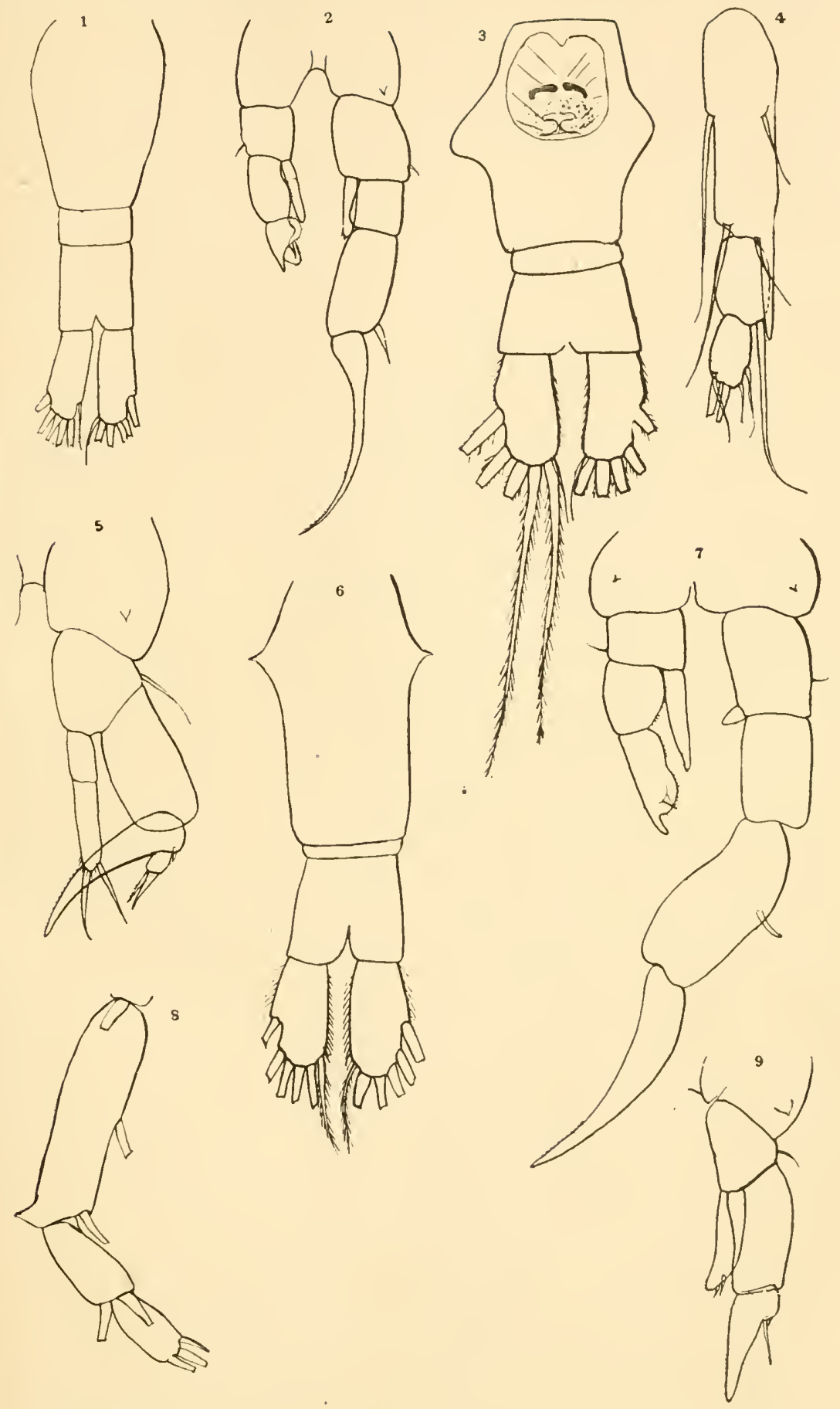

C. D. Marsh del. 

Marsh-North American Species of Diaptomus. 495

PLATE XIX. 
496 Wisconsin Academy of Sciences, Arts, and Letters.

\section{EXPLANATION OF PLATE XIX.}

Fig. 1. Diaptomus Birgei: fifth foot of femalo $(\times 290)$.

Fig. 2. Diaptomus Tyrelli: abdomen of female $(\times 156)$.

Fig. 3. Diaptomus Tyrelbi: fifth feet of male $(\times 190)$.

Fig. 4. Diaptomus siciloides: terminal segments of rlght antenna of male $(\times 290)$.

Fig. 5. Diaptomus siciloides: fifth feet of male $(\times 190)$.

Fig. 6. Diaptomus Birgei: fifth feet of male $(\times 190)$.

Fig. 7. Diaptomus siciloides: abdomen of female $(\times 165)$.

Fig. 8. Diaptomus Tyrelli; fifth foot of female $(\times 290)$. 
Trans. Wis, Acad., Vol. XV.

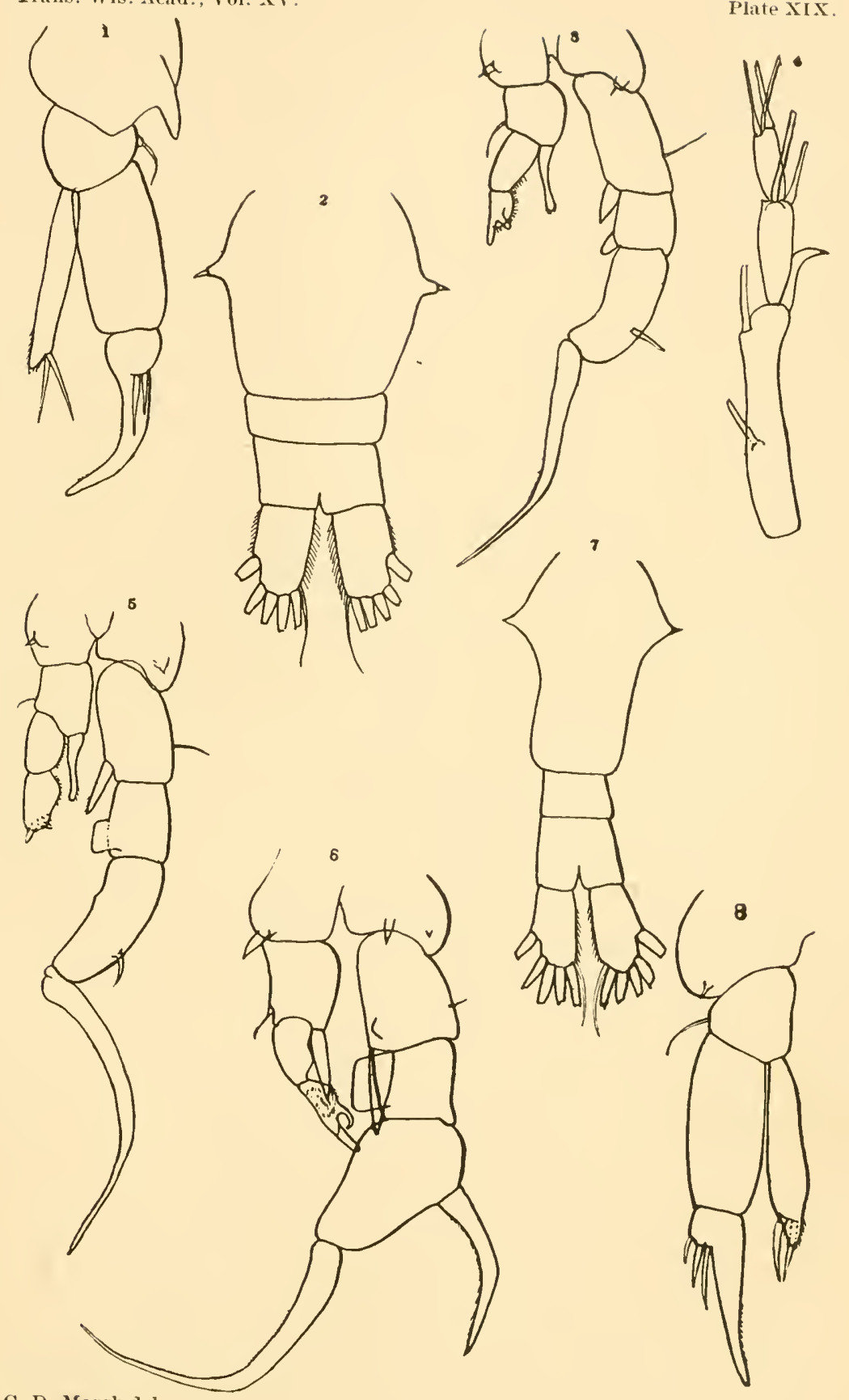

C. D. Marsh del. 

Marsh-North American Species of Diaptomus. 497

PLATE XX.

32-S. \& A. 
498 Wisconsin Academy of Sciences, Arts, and Letters.

\section{EXPLANATION OF PLATE XX.}

Fig. 1. Diaptomus leptopus: fifth foot of female (X 190).

Fig. 2. Diaptomus leptopus: abdomen of female $(\times 158)$.

Fig. 3. Diaptomus leptopus var. piscince: abdomen of female $(\times 76)$.

Fig. 4. Diaptomus conipedatus: abdomen of female (X185).

Fig. 5. Diaptomus leptopus: terminal segments of right antenna of male $(X 290)$.

Fig. 6. Diaptomus leptopus var. piscina: fifth feet of male $(\times 165)$.

Fig. 7. Diaptomus leptopus: fifth feet of male ( $\times 256)$.

Fig. 8. Diaptomus leptopus var. piscince: fifth foot of female $(X 165)$.

Fig. 9. Diaptomus clavipes: fifth foot of female $(\times 165)$. 
Trans, Wis, Acad, Vol. XV.

Plate $\mathbf{X X}$.
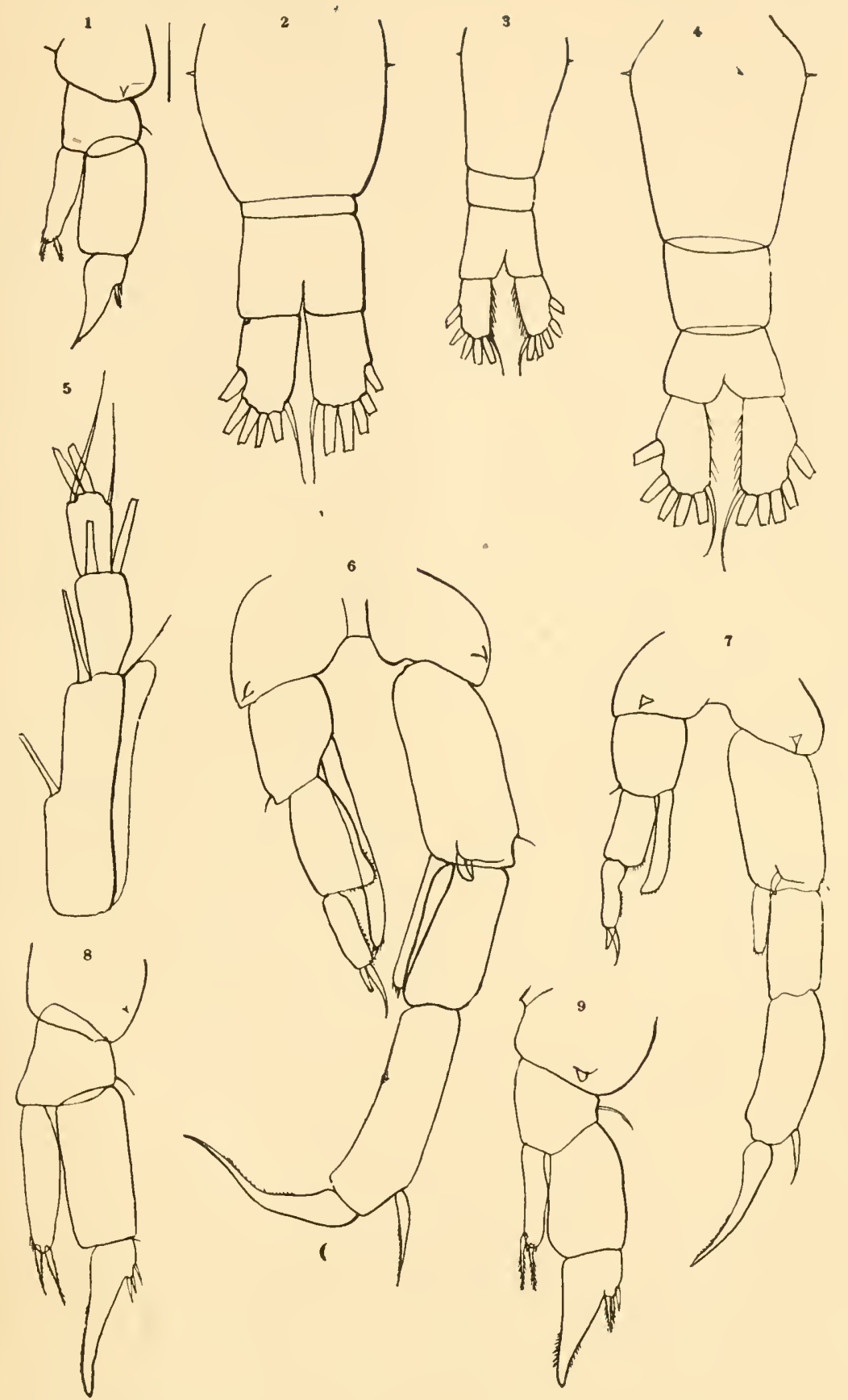

C. D. Marsh del. 

Marsh-North American Species of Diaptomus. 499

PLATE XXI. 
500 Wisconsin Academy of Sciences, Arts, and Letters.

\section{EXPLANATION OF PLATE XXI.}

Fig. 1. Diaptomus clavipes: abdomen of female $(\times 190)$.

Fig. 2. Diaptomus conipedatus: fifth feet of male $(X 190)$.

Fig. 3. Diaptomus conipedatus: terminal segments of right antenna of male $(\times 290)$.

Fig. 4. Diaptomus conipedatus: fifth foot of female $(\times 290)$.

Fig. 5. Diaptomus clavipes: fifth feet of male $(X 114)$.

Fig. 6. Diaptomus clavipes: terminal segments of right antenna of male $(X 190)$.

Fig. 7. Diaptomus leptopus var, piscince: terminal segments of right antenna of male $(X 165)$.

Fig. 8. Diaptomus signicauda: terminal segments of right antenna of male $(\times 290)$.

Fig. 9. Diaptomus nudus: fifth foot of female (X267).

Fig. 10. Diaptomus signicauda: fifth foot of female ( $\times 165)$.

Fig. 11. Diaptomus signicauda: abdomen of female ( $\times 165)$. 
Trans. Wis. Acad., Vol. XV.

Plate XXI.
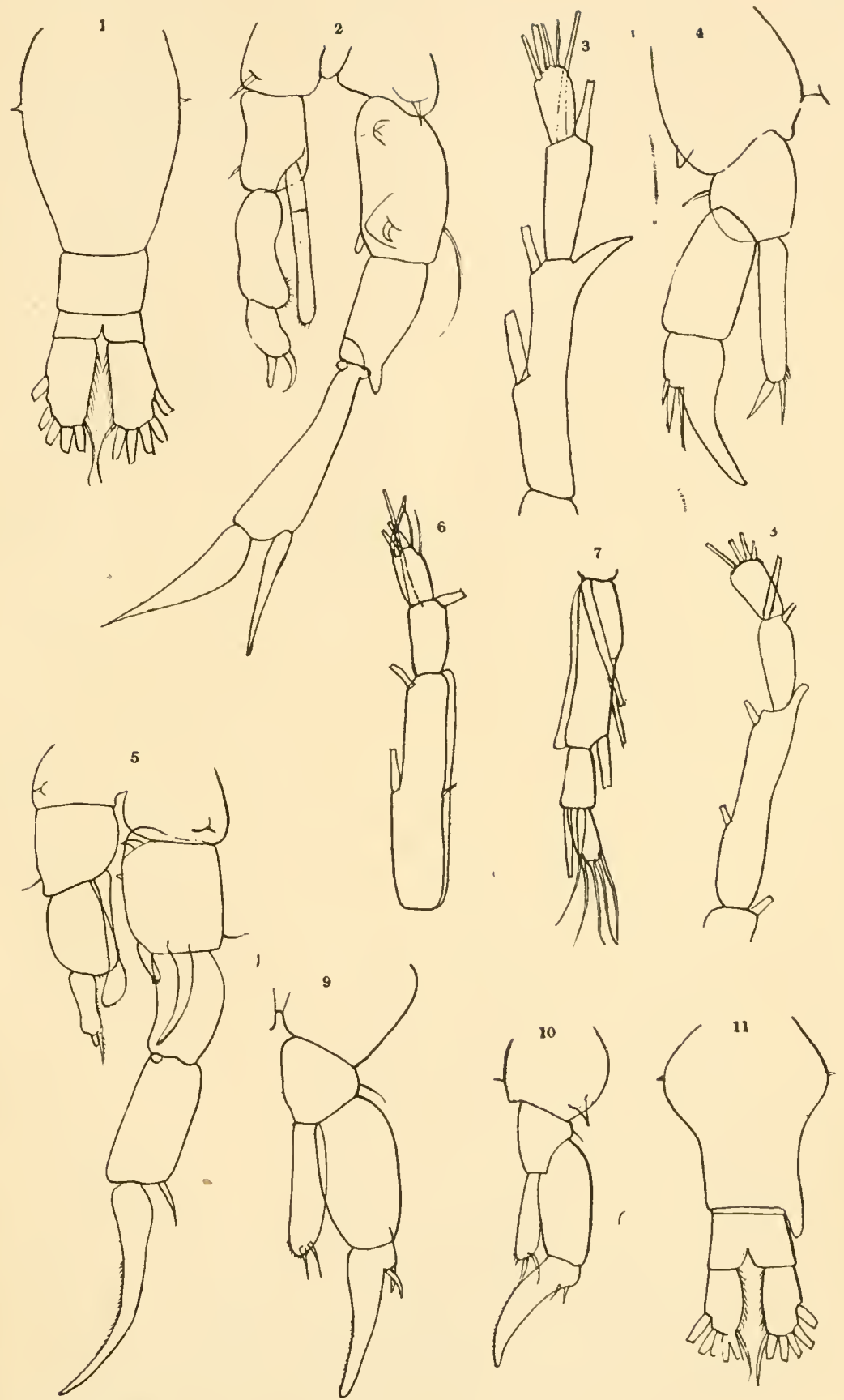

C. D. Marsh del. 
$\therefore \quad y$ 
Marsh-North American Species of Diaptomus. $\quad 501$

PLATE XXII. 
502 Wisconsin Academy of Sciences, Arts, and Letters.

\section{EXPLANATION OF PLATE XXII.}

Fig. 1. Diaptomus nudus: fifth feet of male $(\times 158)$.

Fig. 2. Diaptomus nudus: abdomen of female ( $X 158)$.

Fig. 3. Diaptomus signicauda: fifth feet of male $(X 290)$.

Fig. 4. Diaptomus Judayi: terminal segments of right antenna of male (X290).

Fig. 5. Diaptomus washingtonersis: fifth foot of female $(\times 290)$.

Fig. 6. Diaptomus Judayi: iffth feet of male $(\times 290)$.

Fig. 7. Diaptomus nudus: terminal segments of right antenna of male $(\times 267)$.

Fig. 8. Diaptomus washingtonensis: terminal segments of right antenna of male $(\times 290)$.

Fig. 9. Diaptomus washingtonensis: fifth feet of male $(\times 190)$. 
Trans. Wis, Acad., Vol. XV.

Plate XXII.

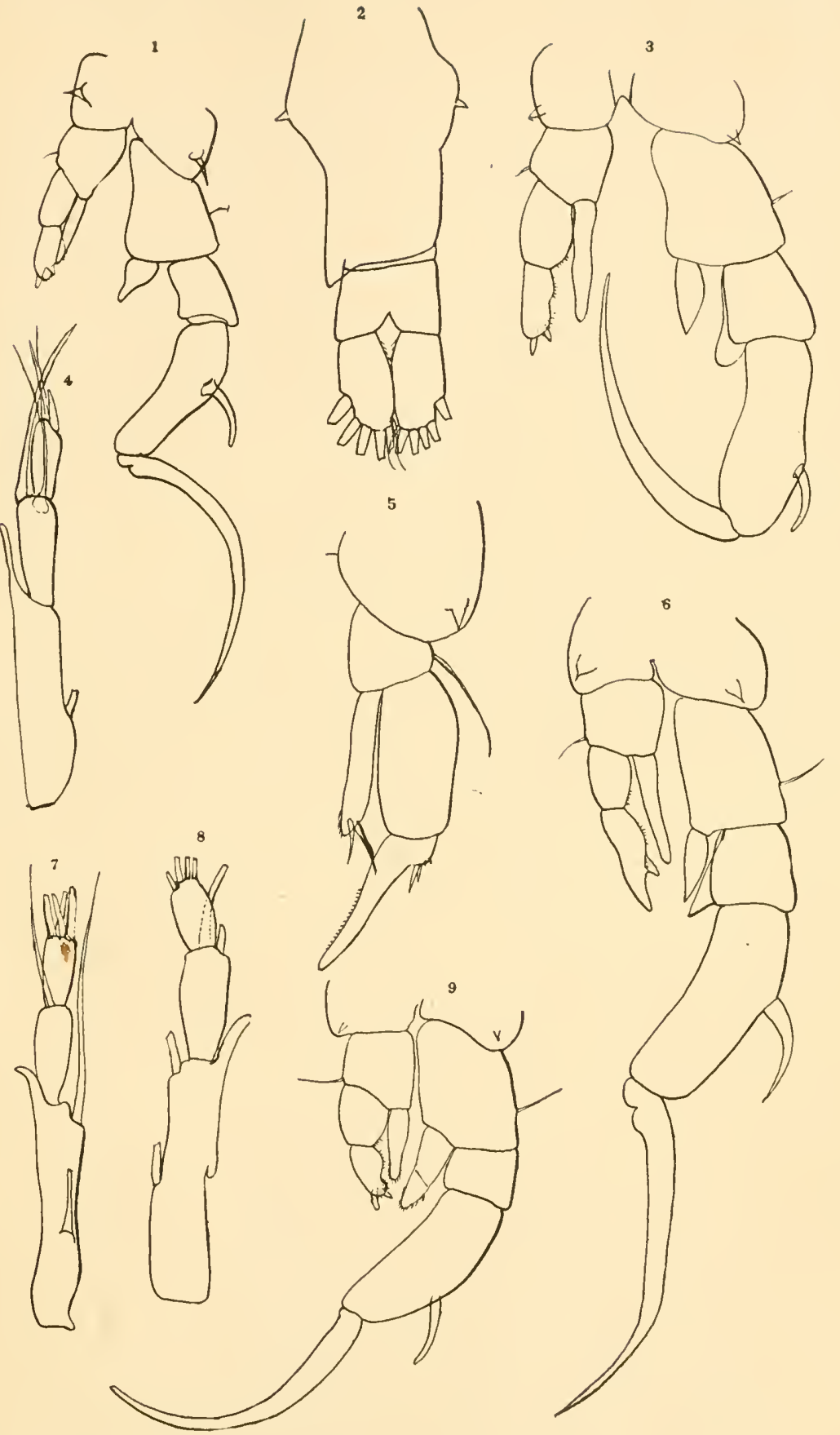

C. D. Marsh del. 

Marsh-North American Species of Diaptomus. 503

\section{PLATE XXIII.}


504 Wisconsin Academy of Sciences, Arts, and Letters.

\section{EXPLANATION OF PLATE XXIII.}

Fig. 1. Diaptomus Judayı: abdomen of female ( $\times 165)$.

Fig. 2. Diaptomus washingtonensis: abdomen of female $(\times 165)$.

Fig. 3. Diaptomus signicauda: abdomen of female $(\times 165)$.

Fig. 4. Diaptomus saltillinus: terminal segments of right antenna of male $(\times 290)$.

Fig. 5. Diaptomus Judayi: fifth foot of female ( $\times 290)$.

Fig. 6. Diaptomus saltillinus: fifth feet of male $(\times 190)$.

Fig. 7. Diaptomus saltillinus: fifth foot of female $(\times 290)$.

Fig. 8. Diaptomus dorsalis: fifth foot of male $(\times 290)$.

Fig. 9. Diaptomus dorsalis: profile of last cephalothoracic segment of female $(X 165)$.

Fig. 10. Diaptomus saltillinus: dorsal process of last cephalothoracic segment of female $(\times 290)$. 
Trans. Wis. Acad., Vol. XV.

Plate XXIII.
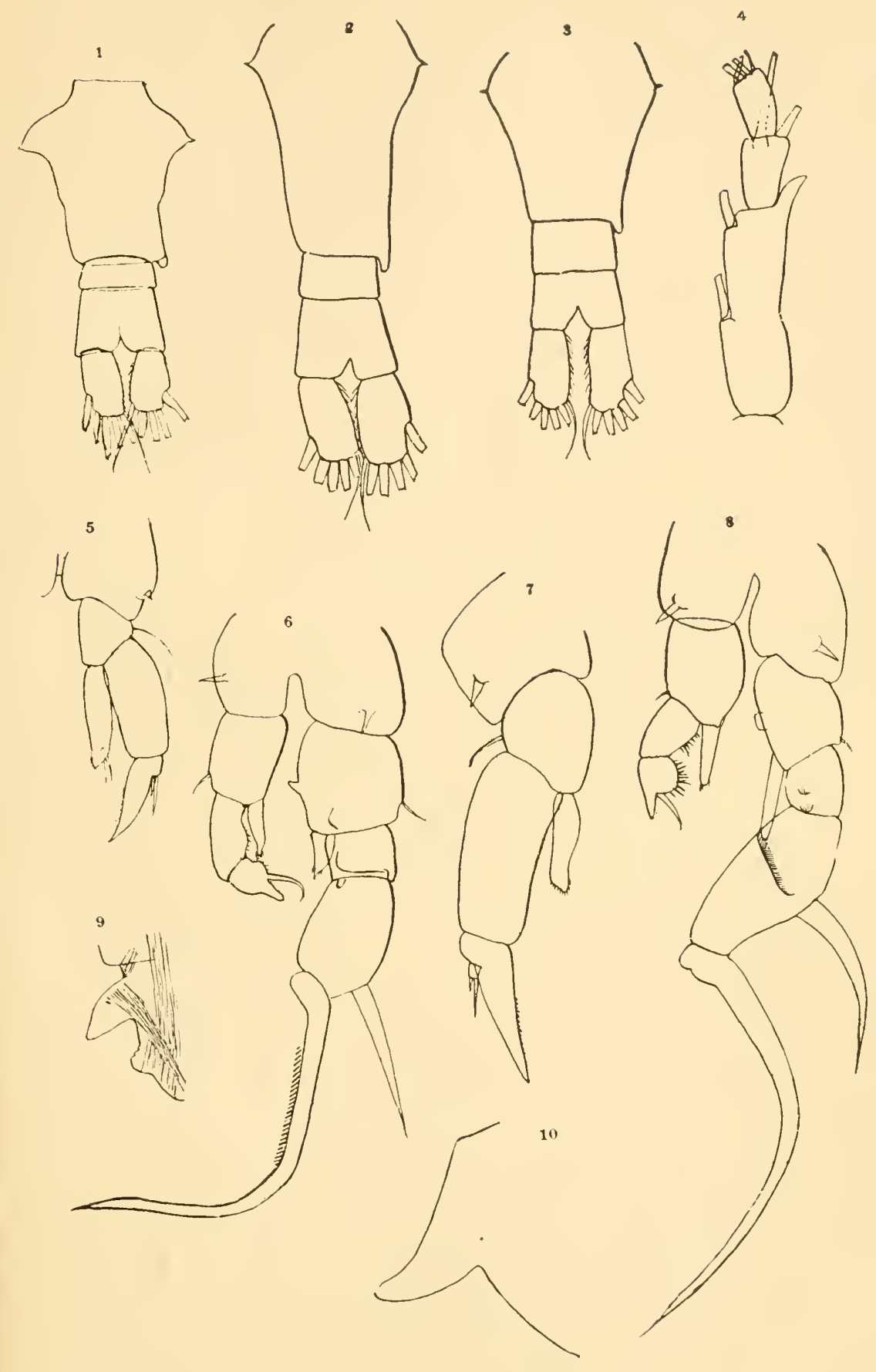

C. D. Marsh del. 

Marsh-North American Species of Diaptomus. 505

\section{PLATE XXIV.}


506 Wisconsin Academy of Sciences, Arts, and Letters.

\section{EXPLANATION OF PLATE XXIV.}

Fig. 1. Diaptomus saltillinus: abdomen of fomale $(X 165)$.

Fig. 2. Diaptomus dorsalis: abdomen of female $(\times 165)$.

Fig. 3. Diaptomus dorsalis: profile of cephalothorax of female $(\times 76)$.

Fig. 4. Diaptomus albuquerquensis: abdomen of female $(\times 100)$.

Fig. 5. Diaptomus dorsalis: terminal segments of right antenna of male $(\times 290)$.

Fig. 6. Diaptomus dorsalis: fifth foot of female (X290).

Fig. 7. Diaptomus albuquerquensis: terminal segments of right antenna of male $(\times 172)$.

Fig. 8. Diaptomus albuquerquensis: fifth feet of male $(\times 75)$.

Fig. 9. Diaptomus albuquerquensis: spines of left side of last cephalothoracic segment of female $(\times 180)$.

Fig. 10. Diaptomus albuquerquensis: dorsal process of last cephalothoracic segment of female $(\times 180)$. 
Trans. Wis. Acad., Vol. XV.
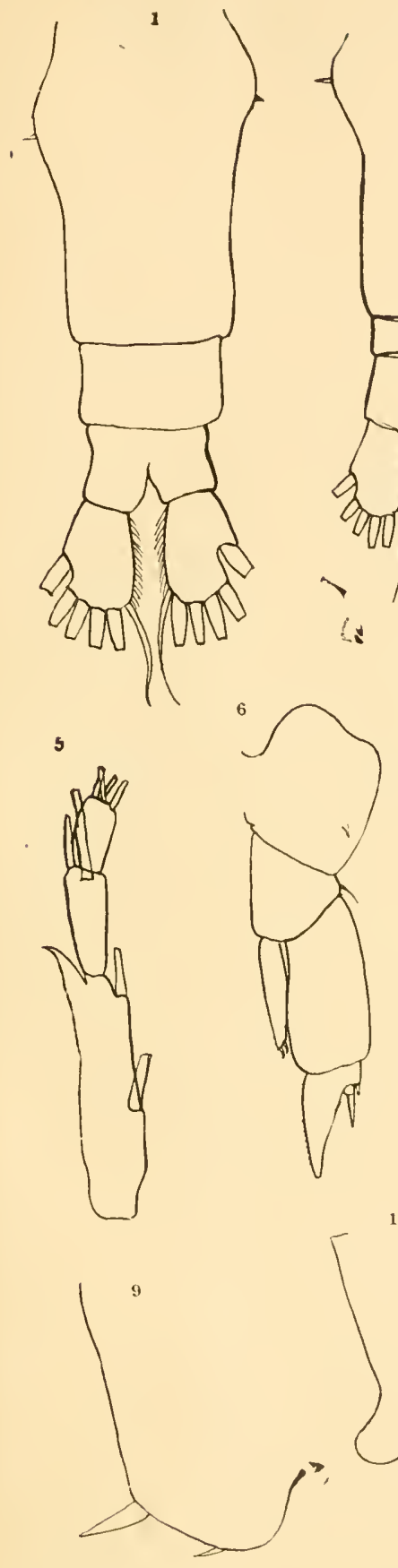

11)

C. D. Marsh del.
Plate XXIV.
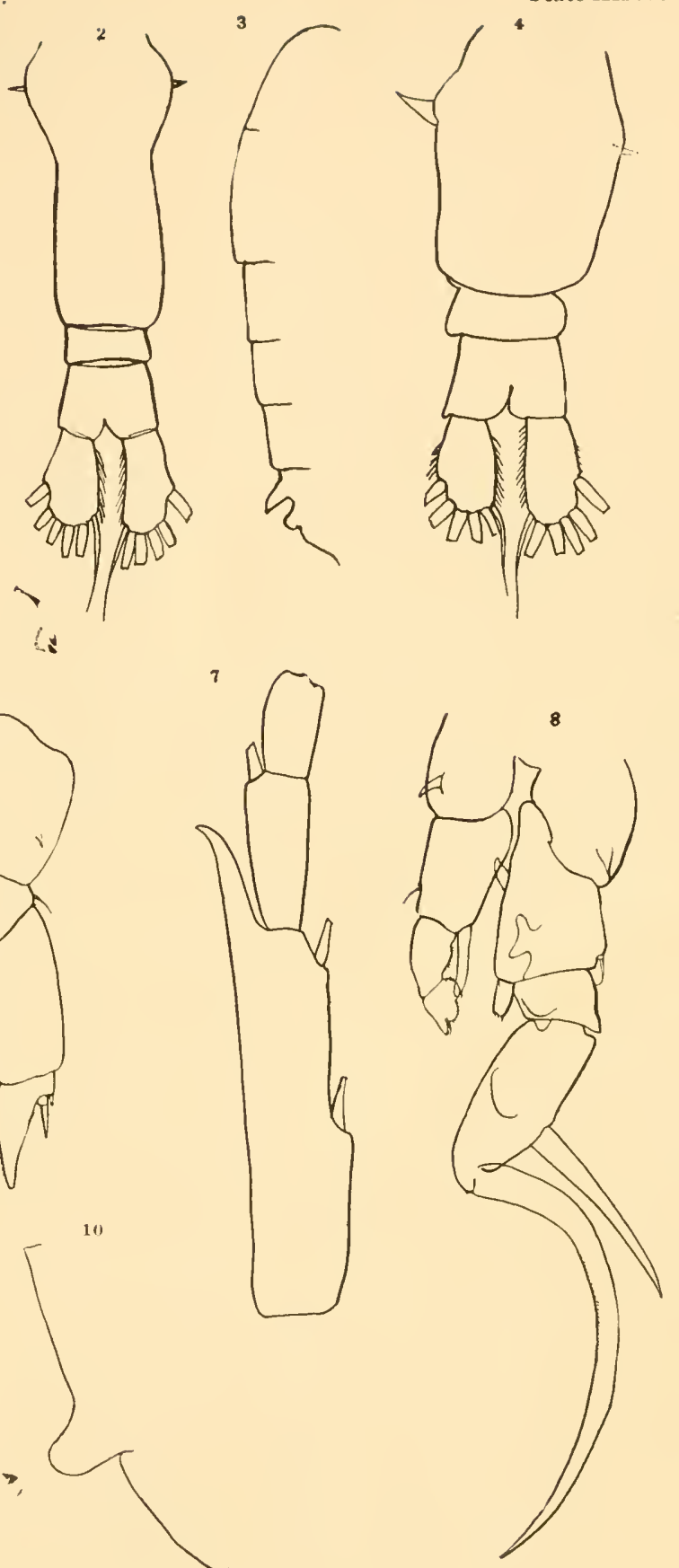

Marsh-North American Species of Diaptomus. 507

PLATE XXV. 
508 Wisconsin Academy of Sciences, Arts, and Letters.

\section{EXPLANATION OF PLATE XXV.}

Fig. 1. Diaptomus albuquerquensis: fifth foot of female ( $\times 180)$.

Fig. 2. Diaptomus sanguineus: terminal segments of right antenna of male $(\times 290)$.

Fig. 3. Diaptomus Eiseni: fifth feet of male $(\times 76)$.

Fig. 4. Diaptomus purpureus: fifth feet of male (X 108).

Fig. 5. Diaptomus sanguineus: fifth foot of female ( $X 165)$.

Fig. 6. Diaptomus asymmetricus: fifth feet of male ( $\times 205)$.

Fig. 7. Diaptomus purpureus: terminal segments of right antenna of male $(X 180)$.

Fig. 8. Diaptomus sanguineus: fifth feet of male ( $\times 165)$. 


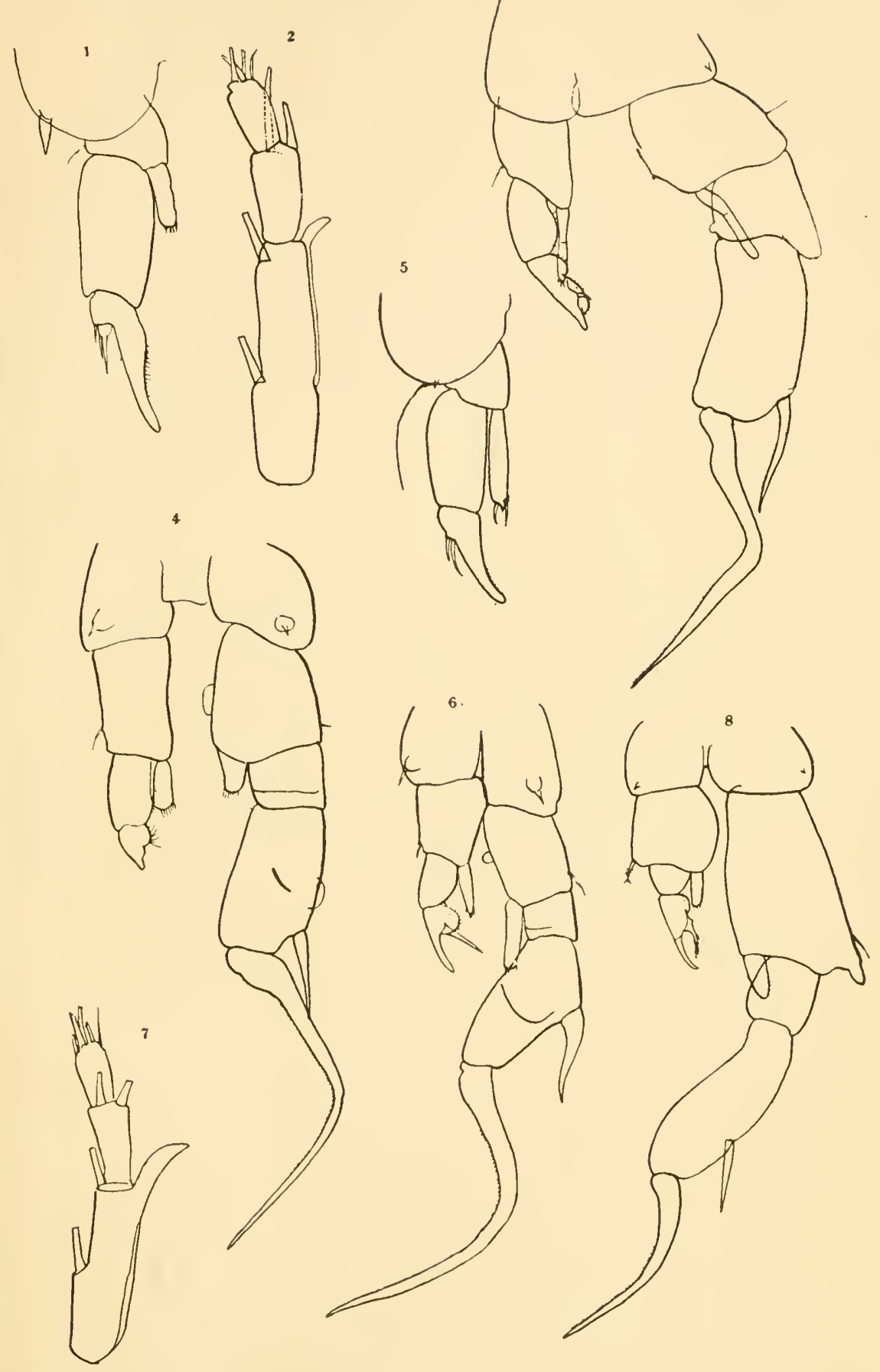

C. D. Marsh del. 

Marsh-North American Species of Diaptomus. 509

\section{PLATE XXVI.}


510 Wisconsin Academy of Sciences, Arts, and Letters.

\section{EXPLANATION OF PLATE XXVI.}

Fig. 1. Diaptomus asymmetricus: terminal segments of right antenna of male ( $\times 267)$.

Fig. 2. Diaptonis purpureus: fifth foot of female $(\times 180)$.

Fig. 3. Diaptomus asymmetricus: fifth foot of female (X267).

Fig. 4. Diaptomus asymmetricus: abdomen of female (X 158).

Fig. 5. Diaptomus purpureus: abdomen of female $(\times 69)$.

Fig. 6. Diaptomus Eiseni: fifth foot of female. After DeGuerne and Richard.

Fig. 7. Diaptomus franciscanus: abdomen of female. After IreGuerne and Richard.

Fig. 8. Diaptomus Eiseni: terminal segments of right antenna of male. After DeGuerne and Richard.

Eig. 9. Diaptomus novamexicanus: fifth feet of male. After Herrick and Turner.

Fig. 10. Diaptomus novamexicanus: fifth foot of female. After Herrick and Turner.

Fig. 11. Diaptomus franciscanus: terminal segments of right antenna of male. After DeGuerne and Richard. 
Trans. Wis. Acad., Vol. XV.

Plate XXr.
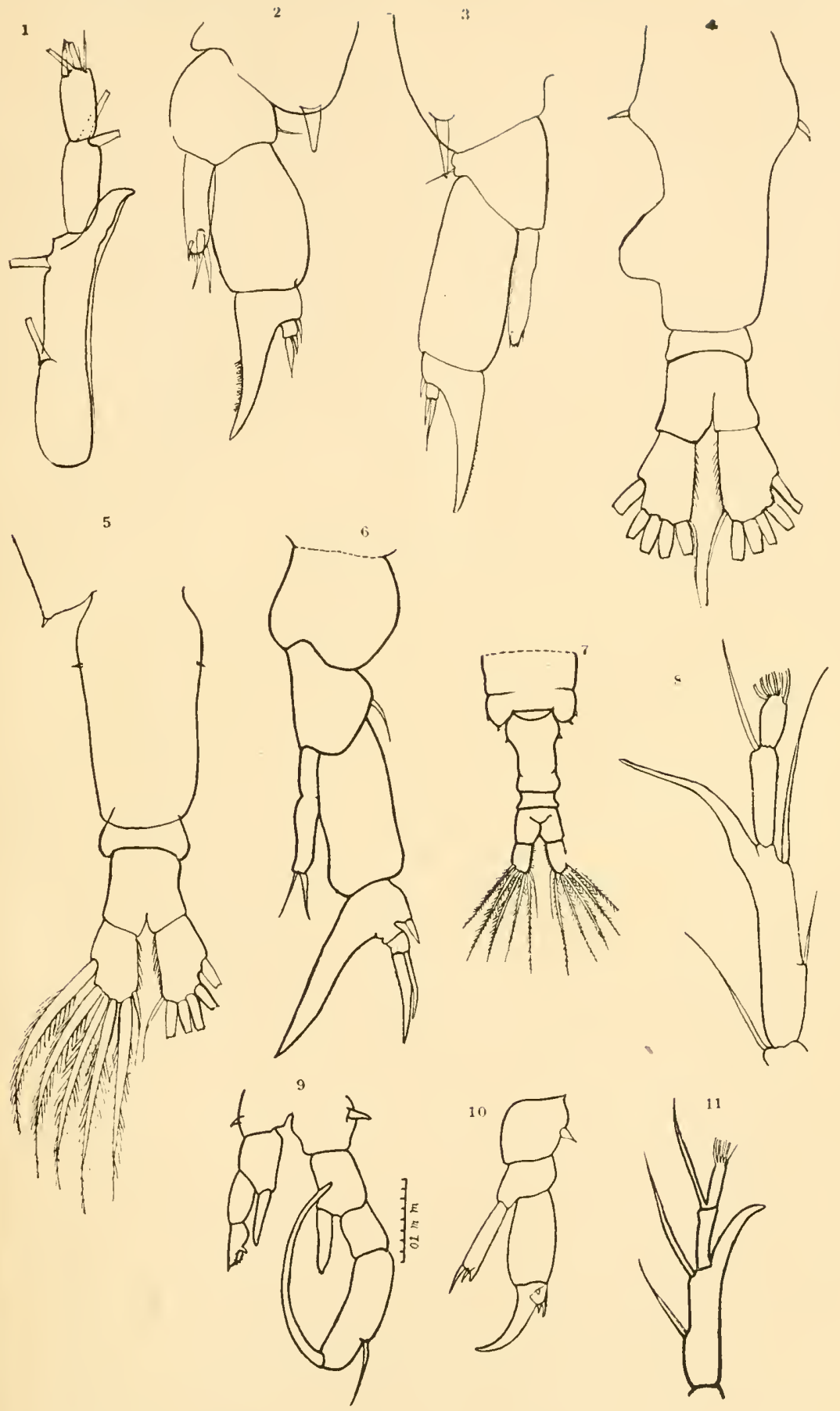

C. D. Marsh del.
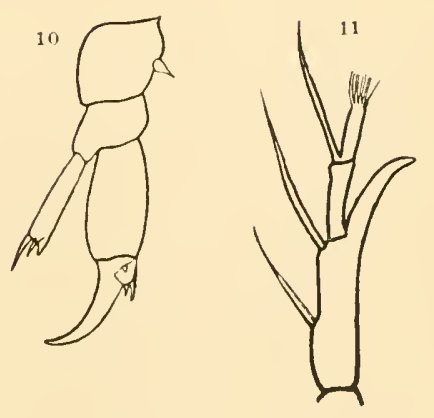

Marsh-North American Species of Diaptomus. $\quad 511$

PLATE XXVII. 
512 Wisconsin Academy of Sciences, Arts, and Letters.

\section{EXPLANATION OF PLATE XXVII.}

Fig. 1. Diaptomus franciscanus: fifth foot of female. After DэGuorne and Richard.

Fig. 2. Diaptomus franciscanus: fifth feet of male. After DeGuerne and Richard.

Frig. 3. Diaptomus stagnalis: fifth foot of fomale. After Forbes.

Fig. 4. Diaptomus Lintoni: fifth foot of female. After Forbes.

Fig. 5. Diaptomus Lintoni: fifth feet of male. After Forbes.

Wig. 6. Diaptomis stagnalis: fifth feet of male. After Herrick and Turner.

Fig. 7. Diaptomus Lintoni: terminal segments of right antenna of male After Forbes.

Fig. 8. Diaptomus stagnalis: female. After Herrick and Turner. 
Trans. Wis. Acad., Vol. XV.
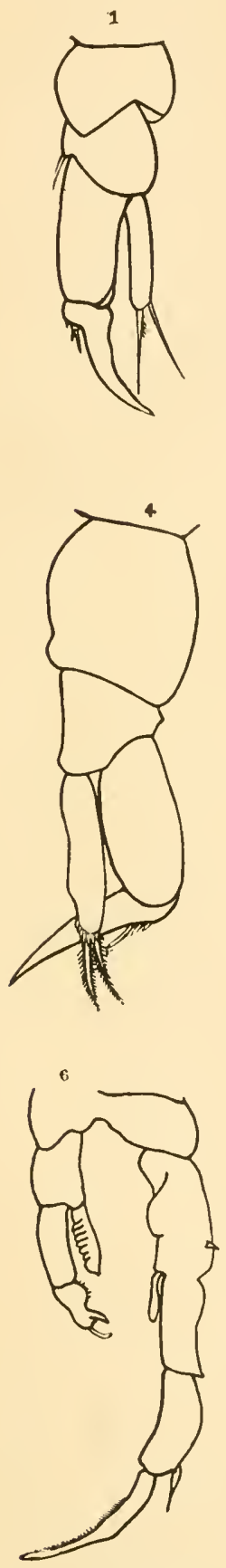

C. D. Marsh del.

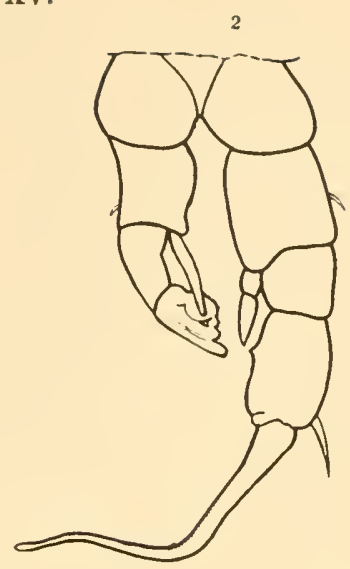

Plate $\mathbf{X X V}$ iI.
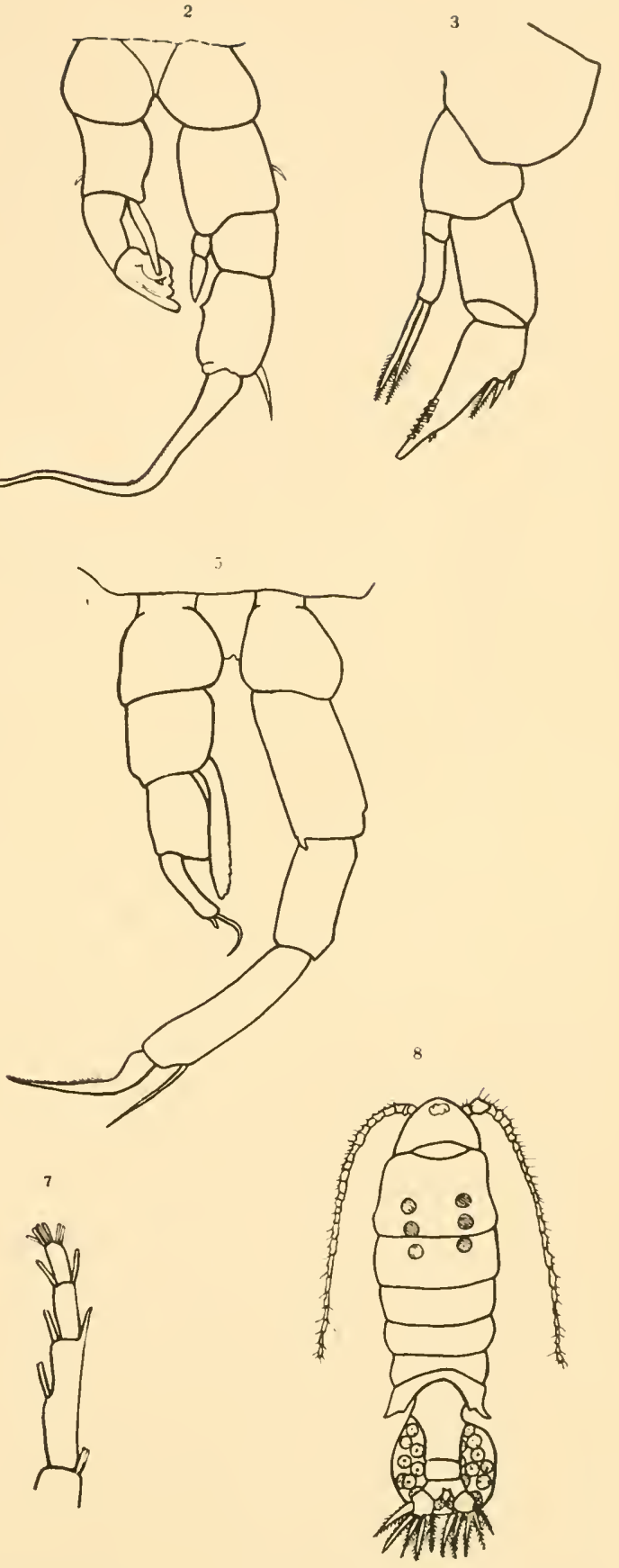

Marsh-North American Species of Diaptomus.

PLATE XXVIII.

33-S. A. 
514 Wisconsin Academy of Sciences, Arts, and Letters.

\section{EXPLANATION OF PLATE XXVIII.}

Fig. 1. Diaptomus Trybomi: abdomen of female. After DeGuerne and Richard.

Fig. 2. Diaptomus Trybomi: fifth feet of male. After DeGuerne and Richard

Fig. 3. Diaptomus Trybomi: $23 \mathrm{~d}$ and 24 th segments of right antenna of male. After DeGuerne and Ricbard.

Fig. 4. Diaptimis Tryborni: fith fo t of female. After DeGuerne and Richard. 
Trans. Wis. Acad., Vol. XV.

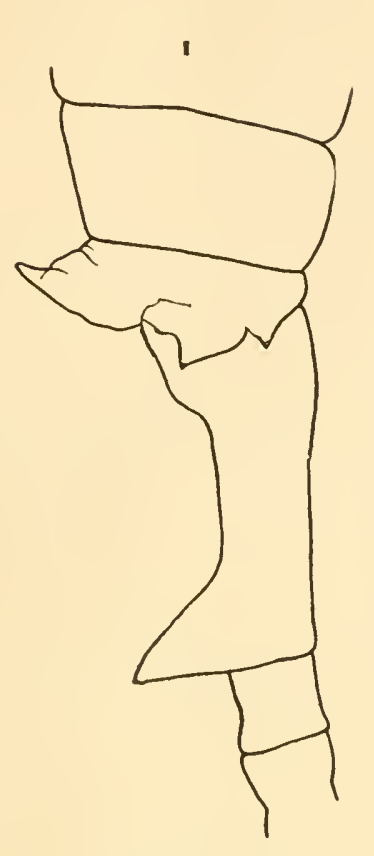

3

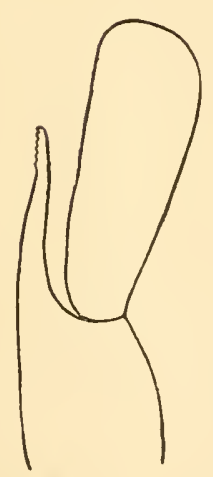

C. D. Marsh del.
Plate XXVIII.

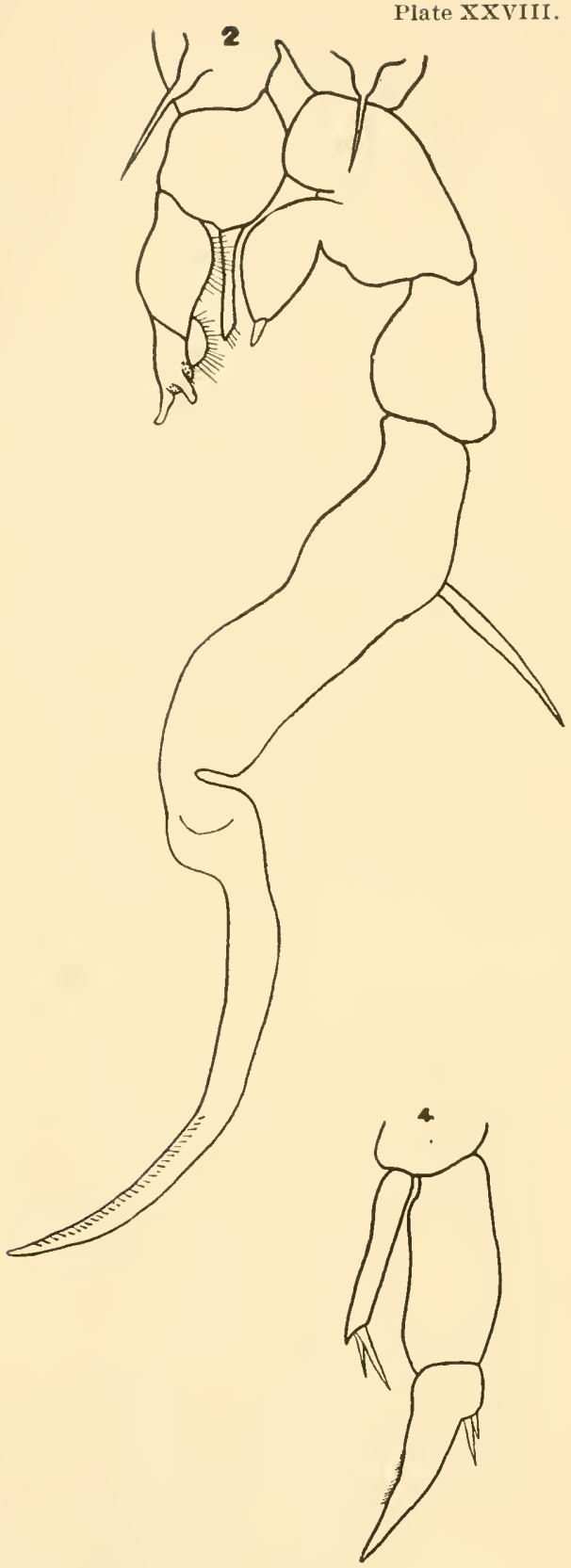





\title{
INDEX.
}

\begin{abstract}
Affinties of species, 354 .
Albuquerquensis group, 398, 401.

D. purpurcus, 399. 399, 476.

D. mymacus, $409,411$.

Altitude, as affecting distribution, 400 . H. Reighurdi, 356, 391, 392, 400, 412.

Alturas lake, 442 .

Beaver island, 413.

Bibllography, 455 .

Birch lake, 42s.

Boulder lake, 460 .

Cedal lake, $400,440$.

Chain o' Lakes, $42 \mathrm{~s}$.

D. spatulocrenatus, 396, 397, 456.

ment, 356.

Collections, distribution of, 382 .

Crève Coeur lake, 440 .

Dead lake, 433 , 462 .

Dinptomus, diagnosis of genus, 401.

D. saltillinus. $398,399,401,469,473$.

-i). sanduincus, $399,47 \mathrm{~S}$.

-1). shoshone, 394, 431.

-I) sicilis, 394, 395, 400, 424.

-1). siciloides, 386, 394, 395, 400, 438.

D. signicauda, 397, 398, 458, 465.

1). tenuicandutus, 394, 395, 400, 422.

-1). Tryjomi, 466.

-14. Tyrelli, 441 .

D. Wailli. $394,433$.

D. Washingtonensis, 397, 398, 462 .
\end{abstract}

-D. albuquerquensis, 398, 399, 401, 469, $471,473$.

D. armatus, $4 \mathrm{S1}$.

$>$ D. Ashlandi, 394, 395, 400, 429 .

D. asymmetricus. $398,399,474$.

D. Bakcri, 391, 392, 393, 400, 420 .

-D. Birgei, 356, 394, 395, 400, 435.

-D. clavlpes, $396,397,400,451$.

D. conipedatus, 396, 397, 401, 449 .

D. dorsalis, 398, 299, 467, 473.

-D. Eiseni, 399.481 .

-D. franciscanus, 391, 392. 393, 400, 418.

D. gigunteus, 446 .

D. Judayi, 397, 39., 464 .

D. Lehmeri, 471.

-D. leptopus, 39ij, 397. 400, 443 .

$-D$. leptopus rar. piscince, $396,445$.

-D. Lintorai, 396, 397. 400, 454.

D. longicovinis var. leptopus, 443 .

n. minnetonka, 478 .

-D. minutus, 394. 395, 400, 426.

Iistribution of the Diaptomi, controlling fractors. 400 .

Distribution of species, 386 .

Diepanolus. :3S4.

Eikhart lake, 428.

Geneva lake, 428.

Gengraphical distribution, 356 .

filacial period, effect of on distribution, 385.

Glen lake, 423.

Green lake, 395. 426, 428.

Halitat. relation of to structure, 388 .

Heart lake, 418.

IIosketts lake, 460 .

Intermediate lake, 413.

climate. effect of on species development. 3sti, $38 s$.

Key to species, 403.

Iagunita, lake, 4 :2.

Latitude. species distributed accordin to. 388 .

D. mississippiensis, 391, 392, 400, 414, Leptopus group, 396.

474 .

D. nebraskensis, 451 .

-D. noramexictnus, 483 .

D. nudus, $397,398,460$.

- D. orcyonensis. 391. 392. 393, 400, 409

- D. pallidus, :991, 392, 393, 400, 416.

$D$ pallilus var. sicilis, 424.

-D. piscinae, 445 .

Limnetic and shallow water forms, dleferences hetween. 388 .

Littoral and limnetic forms, differences between, iss.

Maple lake. 428.

Michigamme, Lake, 426 .

Michigan, Iake, 402.

Minnequa, Iake, $41 \mathrm{~S}$. 


\section{Wisconsin Academy of Sciences, Arts, and Letters.}

Mlrror lake, $433,462$.

Origin of genus Diaptonius, 384.

Oregonensis group, 391, 400 .

Plne lake, 426, 430.

Primitive species, where located, 385.

Primitive structural claracters, 390.

Rocks, Lake, 433, 462.

Round lake, 431.

St. Clalr, Lake, 428.

Seeley iake, 426.

Bhaliow water and limnetic forms, differences between, 388 .

Shoslione, Lake, 433.

Signicauda group, 397, 401.
Species distinctions, bases of, 385 .

Stone lake, 428.

Structure, relation of to habitat, 388 .

Summit lake, 442.

Tenuicaudatus group, 394, 400.

Tomahawk lake, 426 .

Tulare, Lake, 440.

Turkey lake, 440 .

Twin lakes, 465 .

Typical copepod appendage, 390.

Water carriage, distribution by, 400.

West Okoboji lake, 453.

Wluona lake, 437. 



SMITHSONIAN INSTITUTION LIBRARIES 